\title{
Recent bioreduction of hexavalent chromium in wastewater treatment: A review
}

\author{
Debabrata Pradhan $^{\text {a }}$, Lala Behari Sukla ${ }^{\mathrm{a}, 1}$, Matthew Sawyer ${ }^{\mathrm{b}}$, Pattanathu K.S.M. Rahman ${ }^{\mathrm{b}}$
}

a. Multi-Disciplinary Research Cell, Siksha 'O' Anusandhan University, Bhubaneswar751030, India

b. Technology Futures Institute, School of Science and Engineering, Teesside University, Middlesbrough, $U K$

\begin{abstract}
Hexavalent chromium $(\mathrm{Cr}(\mathrm{VI}))$ in water is a proven carcinogen to different internal and external organs of the living organisms. There are different human activities incorporated to the anthropogenic sources in the environment enriching $\mathrm{Cr}(\mathrm{VI})$ of high concentration in the water system above the regulatory level. The physical, chemical and biological properties of chromium favour the dissolution in the water environment. This concerns the environmental researcher to tackle and mitigate. Chemical or biological techniques or a combination of the two have been used to remove $\mathrm{Cr}(\mathrm{VI})$ from polluted waters. Biological techniques include integrated bioremediation, such as the primary processes of direct bioreduction and biosorption, and secondary processes of microbial fuel cell, biostimulation, surface modified dry biomass and biochar adsorption, and engineered biofilm and cell free reductase. These techniques are used by a wide range of living organisms including bacteria, fungi, plants, plant leaves, plant nuts and algae. This group of living organisms transform and remove $\mathrm{Cr}(\mathrm{VI})$ from water during the cellular metabolisms, extracellular activities, physical and chemical adsorptions on the cell surface, and photosynthesis. Variation of different physical, chemical and environmental parameters affecting the efficiency of the bioremediation process have impacted on the design of bioreactors. There has been a recent development of a microbial fuel cell which use the proximity of $\mathrm{Cr}(\mathrm{VI})$ reduction as a cathode half cell for the generation of renewable energy and simulation of its' removal from water.
\end{abstract}

Kewwords: Hexavalent chromium; Wastewater treatment; Toxicity; Bioreduction mechanism; Bioremediation

${ }^{1}$ Address for correspondence: Email: suklalb@yahoo.co.in , Phone: +91-9937081852, Professor, Multi -Disciplinary Research Cell, Siksha 'O' Anusandhan University, Khandagiri Square, Near PNB, Bhubaneswar-751030, Odisha, India 


\section{Outline}

1. Introduction

2. Chemistry of Chromium Causing Contaminations

3. Toxicity of Chromium

4. Chromium Reduction

4.1 Comparison of conventional and bioremediation methods

4.2 Biological reduction mechanism

5. Bioreduction of $\mathrm{Cr}(\mathrm{VI})$

5.1 Bacteria

5.2 Fungi

5.3 Phyto species

5.4 Algae

5.5 Plant nuts

5.6 Biochar

6. Biostimulation

7. Microbial Fuel Cell

8. Conclusion

9. References

\section{Introduction}

Environmental pollutants can be widely dispersed in the biosphere from pond to ocean, grassland to mountain, troposphere to exosphere, natural to built-up ecosystem [1,2]. Pollutants can cause drastic changes in the physical, chemical and mechanical properties of the abiotic components resulting in numerous changes to the biodiversity. This concerns sustainable development of pollution control found almost in every scientific, social, or political agenda all over the world. Many developed and developing countries are implementing new regulations or amendments to old regulations for prevention, control and abatement of the environmental pollutions [3,4]. Also many countries are executing different missions, awareness programs and workshops in the socioeconomical forums. Worldwide, many researchers are working to tackle and mitigate the effects of the various environmental pollutions. 
Pollution of water is a major environmental problem resulting from the hydrological cycle. There are many non-degradable, toxic or otherwise harmful chemicals produced by a variety of different sources such as manufacturing industries and other human activities that contaminate water supplies [5]. Hexavalent chromium $\mathrm{Cr}(\mathrm{VI})$ is an important water pollutant. Even at $\mathrm{Cr}(\mathrm{VI})$ levels measuring in the parts per billion (ppb), research has shown it to be toxic. [6] $\mathrm{Cr}(\mathrm{VI})$ can originate from different anthropogenic activities such as chromite mining, leather tanning, pigment synthesis, electroplating and metal finishing.

Heavy metals such as barium, beryllium, cadmium, mercury, lead, chromium, arsenic, copper, selenium, antimony and thallium all cause toxicity in water depending on their concentration. $[3,4]$ The National Primary Drinking Water Regulations of United States Environmental Protection Agency for heavy metals are given in table 1. With the exception of chromium, the toxicity of other heavy metals is accounted by their total concentration irrespective of the oxidation state in the aqueous medium. Chromium is unique among regulated toxic elements in the environment as different chromium species exist, specifically chromium (III) and chromium (VI). [6] Chromium is found in the environment in its natural form as $\mathrm{Cr}(\mathrm{III})$. However, generation of $\mathrm{Cr}(\mathrm{VI})$ is created by the oxidation of $\mathrm{Cr}(\mathrm{III})$ during various industrial processes and is discarded as industrial wastes. The properties of $\mathrm{Cr}(\mathrm{VI})$ are so favorable that it becomes a 'guest' for many physical and chemical components in the environment. Transportation of $\mathrm{Cr}(\mathrm{VI})$ within the terrestrial and aquatic environments is greatly affected by chemical speciation. The affinity to chemical and photochemical redox transformations, precipitation, dissolution, adsorption and desorption processes occurring in individual trophic level of the environment determines the biogeochemical cycle of $\mathrm{Cr}(\mathrm{VI})$ as shown in figure 1 [7]. $\mathrm{Cr}(\mathrm{VI})$ is ultimately consumed by different plant and animal life of the environment. This can cause serious health problem. For example, $\mathrm{Cr}(\mathrm{VI})$ acts 
as an oxidant directly to the surface of skin or absorption can occur through the skin, especially if the skin surface is damaged. Chromium absorbed into the blood system via the lungs is excreted by the kidney and liver. Prolonged absorption causes acute kidney and liver damage due to severe inflammation inside the cells $[6,8]$.

If $\mathrm{Cr}(\mathrm{VI})$ concentrations in the abiotic components of the ecosystem increase above the regulatory standards, stringent legislation for the prevention, control and protection of the environment needs to be considered $[3,4]$.

Environmental concentration of chromium is known to increase due to the industrial developments. Three forms of chromium such as $\mathrm{Cr}(0), \mathrm{Cr}(\mathrm{III})$ and $\mathrm{Cr}(\mathrm{VI})$ are present in the soil, water and biota. Different species of chromium originate from different anthropogenic sources such as chrome alloy production in steel industries, chrome electroplating, airborne emissions from chemical plants and incineration facilities, cement dust, contaminated landfill, effluents from chemical plants, asbestos lining erosion, road dust from catalytic converter erosion and asbestos brakes, tobacco smoke, topsoil and rocks, copier servicing, anti-algae agents, antifreeze, cement, glassmaking and leather tanning. $[9,10]$ In the industrial processes, chromium extraction begins with mining of chromite ores $\left(\mathrm{Cr}_{2} \mathrm{O}_{3}\right)$ or ferrous chromite $\left(\mathrm{FeO} \cdot \mathrm{Cr}_{2} \mathrm{O}_{3}\right)$. These ores are converted to metallic chromium via various stages and processes of oxidation and reduction. [7] There are some direct uses of chromite ores, most notably for the production of refractory bricks. [11] About $90 \%$ of total chromite ores are consumed as an alloying agent in the form of ferrochromium to produce either stainless steel or used in other nonferrous metallurgical industries. The remaining $10 \%$ of chromite ores are used in refractory, cement, glass, ceramic, machinery, leather tanning, electroplating, wood preservation, and pigment industries. [10] World stainless steel producers depend directly or indirectly on chromium supply. According to the mineral commodity 
summaries 2016 by the US Geological Survey, the total world reserve of shipping grade chromite ore is estimated to be more than $480 \times 10^{6}$ metric tons. [12] Kazakhstan has approximately $50 \%$ of world shipping grade chromite ore but South Africa is top for mining ferrous chromite for the last two years. China has emerged as the top stainless steel producer and is the leading chromiumconsuming and ferrochromium-producing country. About $95 \%$ of the world's chromium resources are geographically concentrated in Kazakhstan and southern Africa. The details data is given in table 2 .

Possibility of $\operatorname{Cr}(\mathrm{VI})$ pollution is not surprising due to its chemical compatibility to the environment and wide range of industrial applications. Hence its removal is obvious because of the toxicity effects on the human body. $\mathrm{Cr}(\mathrm{VI})$ removal is gaining importance in the environmental research communities worldwide. Every year numbers of research article have been reported experimenting different techniques. Several review articles have been reported so far summarizing the $\operatorname{Cr}(\mathrm{VI})$ toxicity and removal. [6-10, 13, 19, 44, 48] The major reviews deal with the genotoxicity of $\mathrm{Cr}(\mathrm{VI})$ on human body. Very few reviews deal with $\mathrm{Cr}(\mathrm{VI})$ removal with an emphasison soil pollution rather than water pollution. Every year new techniques have been discovered to remove $\mathrm{Cr}(\mathrm{VI})$ from water, we have attempted to review the bioreduction of $\mathrm{Cr}(\mathrm{VI})$ on the basis of the recent interventions. In addition to the previous reviews, this review gives more data towards the bioreduction of $\mathrm{Cr}(\mathrm{VI})$. We have summarized more than hundred new isolated species from different locations enabling $\mathrm{Cr}(\mathrm{VI})$ tolerance and removal capacity. Some of them are listed in a table form (Table 5).

\section{Chemistry of Chromium Causing Contaminations}


Chromium is a d-Block transition elements and first member of the group 6 of the modern periodic table. Since the ground state electronic configuration of chromium is 'high spin' $[\mathrm{Ar}] 4 \mathrm{~s}^{1} 3 \mathrm{~d}^{5}$, it shows varying oxidation states such as $-2,-1,0,+1,+2,+3,+4,+5$ and +6 with an associated wide range of chemical and physical properties. [13] It can form acidic, alkaline or amphoteric oxides according to the oxidation state. The most stable chromium occurs when the oxidation states are +3 (trivalent, $\mathrm{Cr}(\mathrm{III})$ ) and +6 (hexavalent, $\mathrm{Cr}(\mathrm{VI})$ ). In the water most $\mathrm{Cr}(\mathrm{VI})$ species are $\mathrm{Cr}_{2} \mathrm{O}_{7}{ }^{2-}$, $\mathrm{CrO}_{4}{ }^{2-}, \mathrm{H}_{2} \mathrm{CrO}_{4}$, and $\mathrm{HCrO}_{4}^{-}$. Similarly, $\mathrm{Cr}(\mathrm{III})$ species in solution are most often $\mathrm{Cr}^{3+}, \mathrm{Cr}(\mathrm{OH})_{2}{ }^{+}$, $\mathrm{CrO}^{+}, \mathrm{HCrO}_{2}$ and $\mathrm{CrO}_{2}^{-}$. [8] Chromium metal is a steely-grey colour, has a metallic luster, is hard and brittle, resists tarnishing, and has high melting and boiling points $\left(1,907{ }^{\circ} \mathrm{C}\right.$ and $2,671{ }^{\circ} \mathrm{C}$ respectively). [13,14] Chromium metal is passivated by oxidation reactions and this forms a thin protective surface layer which prevents the diffusion of oxygen onto the underlying metal. Chromium metal shows a BCC crystal system similar to $\alpha$-iron making it competent in stainless steel alloy. These properties make chromium a suitable element to improving alloys and increase corrosion resistivity, change the colour, metallic lusture and/or hardness [15]. $\mathrm{Cr}(\mathrm{VI})$ is an environmental leachate of stainless steel fabrication, which contributes to pollution of $\mathrm{Cr}(\mathrm{VI})$ in water and soils. Due to its high melting point, chromium is added to manufacture refractory bricks and is used in glass and ceramic industries. Chromium metal in refractory bricks is oxidized to $\mathrm{Cr}(\mathrm{VI})$ during the high temperature refractory manufacturing process and can contaminate soil and water due to leaching.

$\mathrm{Cr}(\mathrm{VI})$, as $\mathrm{Na}_{2} \mathrm{CrO}_{4}$, is produced during the lime treatment of chromite or ferrous-chromite ores resulting in further compounds or ions being formed such as $\mathrm{CrO}_{3}, \mathrm{CrF}_{6}, \mathrm{CrOCl}_{4}, \mathrm{H}_{2} \mathrm{Cr}_{2} \mathrm{O}_{7}, \mathrm{Cr}_{2} \mathrm{O}_{7}{ }^{2-}$ , $\mathrm{CrO}_{4}{ }^{2-}, \mathrm{H}_{2} \mathrm{CrO}_{4}$, and $\mathrm{HCrO}_{4}^{-}[16]$. These are highly soluble in water and show strong oxidizing potential. For redox titration $\mathrm{Cr}(\mathrm{VI})$ in the form of sodium dichromate $\left(\mathrm{Na}_{2} \mathrm{Cr}_{2} \mathrm{O}_{7}\right)$ or potassium 
dichromate $\left(\mathrm{K}_{2} \mathrm{Cr}_{2} \mathrm{O}_{7}\right)$ used as oxidizing standards, however, $\mathrm{K}_{2} \mathrm{Cr}_{2} \mathrm{O}_{7}$ is preferable due to the hygroscopic nature of $\mathrm{Na}_{2} \mathrm{Cr}_{2} \mathrm{O}_{7}$. Usually $\mathrm{Cr}(\mathrm{VI})$ does not favor complex formation, but, in presence of hydrogen peroxide it forms peroxo species which capable of forming coordination complexes. In different manufacturing industries, such as the production of dyes and paint pigments, lather tanning, analytical grade chemicals, electroplating, and others, $\mathrm{H}_{2} \mathrm{Cr}_{2} \mathrm{O}_{7}$ is used. The effluents from these industries are the one of the major reasons for $\mathrm{Cr}(\mathrm{VI})$ contamination in the hydrosphere [6].

In contrary trivalent chromium $\mathrm{Cr}(\mathrm{III})$ is very stable in an acidic environment and easily oxidized to $\mathrm{Cr}(\mathrm{VI})$ in an alkaline medium. $\mathrm{Cr}$ (III) compounds form numerous octahedral coordination complexes. The stability is determined by the crystal field stabilization energy from its $\mathrm{d}^{3}$ configuration. $\mathrm{Cr}$ (III) complexes show different colours due to different crystal field transitions in presence of coordinating ligands. The solubility of $\mathrm{Cr}(\mathrm{III})$ compounds is less compared to $\mathrm{Cr}(\mathrm{VI})$ in aqueous medium.. [10]. Below pH 5.0 oxides of $\mathrm{Cr}$ (III) are slightly soluble in water but above pH 5.0 $\mathrm{Cr}$ (III) forms hydrated compounds which are even less soluble. However, $\mathrm{Cr}(\mathrm{VI})$ predominantly forms anionic species in water increasing the solubility to above $60 \mathrm{~g} / \mathrm{L}$ at a wide range of temperatures. The thermodynamic Eh-pH diagram (Pourbaix Diagram, figure 2) shows the stability of $\mathrm{Cr}(\mathrm{III})$ and $\mathrm{Cr}(\mathrm{VI})$ and $\mathrm{pH}$ is an important parameter for the redox chemistry of chromium. The high Eh values prefers oxidizing species and vice versa. In strong acidic conditions $(\mathrm{pH}<1)$ and at high Eh, $\mathrm{Cr}(\mathrm{VI})$ exists as chromic acid $\left(\mathrm{H}_{2} \mathrm{CrO}_{4}\right)$ which is a strong oxidizing agent. Between pH 1.0 and 6.0, anionic species $\mathrm{HCrO}_{4}^{-}$is stable at a high Eh. With decreasing Eh, equilibriums of $\mathrm{HCrO}_{4}{ }^{-}$exist with $\mathrm{Cr}(\mathrm{III})$ from $\mathrm{pH} 1.0$ to 4.0 and with $\mathrm{Cr}(\mathrm{OH})_{2}{ }^{+}$from $\mathrm{pH} 4.0$ to 6.0. Above $\mathrm{pH}$ 6.0 $\mathrm{Cr}(\mathrm{VI})$ exists as $\mathrm{CrO}_{4}{ }^{2-}$ and with decreasing Eh the equilibriums exist with $\mathrm{Cr}(\mathrm{III})$ as $\mathrm{CrO}^{+}$(pH 6.0 to 8.0 ), $\mathrm{HCrO}_{2}$ (pH 8.0 to 9.5) and $\mathrm{CrO}_{2}^{-}$(pH 9.5 to 14.0). Since the 
solubility of $\mathrm{Cr}(\mathrm{VI})$ species is very high at all range of $\mathrm{pH}$, its removal from water is possible by reducing the species to the less soluble $\mathrm{Cr}$ (III). This can be followed by hydration to solidify the reduced species rather than by direct precipitation of $\mathrm{Cr}(\mathrm{VI})$. The adsorption process showed attachment of the anionic species of $\mathrm{Cr}(\mathrm{VI})$ on the polar functional surface in the acidic medium [17]. The hypothetical mechanism of adsorption $\mathrm{Cr}(\mathrm{VI})$ may be as follow accordingly shown in equation 1.

Functional surface $+\mathrm{H}^{+}+\mathrm{CrO}_{4}^{2-}$

$$
\rightarrow(\text { Functional surface- } \mathrm{H})^{+} \ldots\left(\mathrm{CrO}_{4}\right)^{2-} \ldots{ }^{+}(\mathrm{H}-\text { Functional surface })
$$

\section{Toxicity of Chromium}

$\mathrm{Cr}(\mathrm{III})$ is an essential trace element necessary for glucose, lipid and amino acid metabolism. It is a popular dietary supplement seen in table 3 . Chromium is found in different parts of human body as listed in table 4. Chromium occurs in the tissues of human fetuses and infants. From birth its content continues to decrease with increasing age in all body organs except the lungs, in which a slight rise in chromium content is detectable from the 10th year of life, apparently as a consequence of inhaled chromium deposits in the lungs. The highest accumulation of chromium (0.234-3.8 $\mathrm{mg} / \mathrm{kg}$ ) was found in the hair. However, at high concentration, $\mathrm{Cr}(\mathrm{III})$ causes negative effects on cellular structures. Evidence is growing that metabolites of $\mathrm{Cr}(\mathrm{III})$ dietary supplements are partially oxidized to carcinogenic $\mathrm{Cr}(\mathrm{VI}), \mathrm{Cr}(\mathrm{IV})$ and $\mathrm{Cr}(\mathrm{V})$ in vivo by intracellular oxidation. [18] $\mathrm{Cr}(\mathrm{VI})$ forms anionic species $\mathrm{CrO}_{4}{ }^{2-}$ in solution within $\mathrm{pH} 6.0$ as shown in figure 2. The structure of this anionic species is similar to the sulphate ion $\left(\mathrm{SO}_{4}{ }^{2-}\right)$. The $\mathrm{CrO}_{4}{ }^{2-}$ ion can substitute the $\mathrm{SO}_{4}{ }^{2-}$ and be transported via the sulphate transport system and enters in to the cells. [19] As Cr(VI) is a 
strong oxidizer and, when combined with different reducing agents inside the cells, forms intermediates of $\mathrm{Cr}(\mathrm{V})$ and $\mathrm{Cr}(\mathrm{IV})$ before conversion to $\mathrm{Cr}(\mathrm{III})$ as an end product. During the reduction of $\mathrm{Cr}(\mathrm{VI})$ to $\mathrm{Cr}(\mathrm{III})$ the formation of different reactive species like nascent oxygen $(\mathrm{O})$, superoxide ions $\left(\mathrm{O}_{2}^{-}\right)$, hydroxyl ions $\left(\mathrm{OH}^{-}\right)$, peroxo ions $\left(\mathrm{O}_{2} \mathrm{H}^{-}\right)$and free radicals are catalyzed inside the cells. [8] The intracellular generations of the reactive species depend on $\operatorname{Cr}(\mathrm{VI})$ concentration as free radical generation increases with greater chromium exposure. [20] Cellular metabolism of $\mathrm{Cr}(\mathrm{VI})$ can cause both oxidative and non-oxidative forms of DNA damage. The most abundant and specific type of DNA damage is Cr-DNA binding (adducts). This has been detected in reduction reactions in vitro and in various cultured cells which cause mutations and chromosomal breaks [19]. The reactive species produced during the intracellular $\mathrm{Cr}(\mathrm{VI})$ reduction combined with DNA-proteins to forms different intermediate products called oxidative DNA damage. The electrostatic interaction between stable $\mathrm{Cr}(\mathrm{III})$ species and negatively charged phosphate groups of DNA forms mutagenic and toxic Cr(III)-DNA complexes. These complexes affect the natural DNA replication and transcription and can cause mutagenesis. In addition to the formation of metal complexes, $\mathrm{Cr}(\mathrm{VI})$ metabolism has been associated with the production of DNA single-strand breaks [21]. These can alter the function of cells leading to cancers in the liver, kidney and lungs developing. Similarly, different passivation takes place through the skin on direct contact of $\mathrm{Cr}(\mathrm{VI})$, causing dermatitis, dermal necrosis and dermal corrosion. [6] Occupational exposures to $\mathrm{Cr}(\mathrm{VI})$ via inhalation have consistently been found to increase the risk of cancers in the respiratory system [22]. Both highly and poorly soluble chromates were determined to be carcinogenic [23]. Long-term occupational exposure to $\mathrm{Cr}(\mathrm{VI})$ from different chromate industries and chromite mines is a chemical carcinogen that can cause carcinomas of the bronchial systems. Zhang and Li [24] reported increased mortality from stomach cancers among rural residents in the 
Liaoning Province of China where drinking water was heavily contaminated with $\mathrm{Cr}(\mathrm{VI})$ released by the ore smelting facility. $\mathrm{Cr}(\mathrm{VI})$ has shown neurotoxicity by significantly reducing the number of neuronal cells [25]. Cr(VI) develops physiological stress in animals by damaging sperm and male reproductive systems [26].

\section{Chromium Reduction}

\subsection{Comparison of conventional and bioremediation methods}

Hexavalent chromium can be reduced by different conventional physico-chemical processes. This is important to environmental researchers because of the toxicity effects on the human body. Recent developments in the understanding of the conventional process emphasize various methods such as thermal treatment [27], desalination [28], direct reduction [29,30], resin adsorption [31,32,214,217], electrolysis [33,34], electrocoagulation [35,36], activated carbon adsorption [212, 213], composite ceramic adsorption [37, 215, 218], carbon nano fibers adsorption [211, 216], nano materials catalyzed reduction [38,39], and catalytic reduction [40,41]. The conventional processes are complex due to the different intensive sub-processes and use of large amounts of chemicals and generation of toxic sludges. [13,42,43] Carbothermal reduction of $\mathrm{Cr}(\mathrm{VI})$ was conducted by adding carbon at temperature ranging from 1000 to $1400^{\circ} \mathrm{C}$ in a TGA apparatus with particle size limitation of the $\mathrm{Cr}(\mathrm{VI})$ contaminated soil sample [27]. To achieve a complete reduction $15 \%$ carbon was added to soil, however, evaluation of $\mathrm{CO}_{2}$ emission was ignored during the process. A complex electrochemical desalination method used to reduce $\mathrm{Cr}(\mathrm{VI})$. [28] In the process two costly membranes were used to separate the desalination chamber from anode and cathode [28]. Similarly in the other conventional methods, stringent chemical environments were 
employed in the complex designed reactors to reduce/adsorb the $\mathrm{Cr}(\mathrm{VI})$. Synthesis of different nano materials, carbon fibers, composites, costly resins were used in the conventional methods for the reduction/adsorption of $\mathrm{Cr}(\mathrm{VI})$ making the process more complicated in terms of cost evaluation and eco-friendliness. [28-43, 211-218] The in-situ reduction of $\mathrm{Cr}(\mathrm{VI})$ from water does not favour the conventional process as it has multiples steps to set up the pilot scale operation at the location of the pollution. When considering all the demerits of the conventional methods, the focus has been shifted to better alternative treatment methods. Biological detoxification of $\mathrm{Cr}(\mathrm{VI})$ to relatively less toxic and less mobile $\mathrm{Cr}$ (III) is likely to be a useful process for the remediation of contaminated waters and soils compared to the chemical processes $[44,45]$. The biological processes occur in natural cellular metabolisms of the biological species remediating $\mathrm{Cr}(\mathrm{VI})$ from different resources. The details of the biological reduction mechanism are discussed in the following section. From the mechanism, the reasons why the biological method are superior to the conventional processes can be elucidated. This has stimulated the interest in microorganisms that can use $\mathrm{Cr}(\mathrm{VI})$ as an electron acceptor. The biological detoxification involves different inner and outer cellular reactions such as direct reduction by chromium reducing bacteria, biosorption, and phytoremediation, and indirect reduction by application of different electron shuttles, bioremediation, and bioaccumulation [13,46]. The ascorbate with glutathione and cysteine produced during the cellular metabolism is responsible for more than $95 \%$ of $\mathrm{Cr}(\mathrm{VI})$ reduction $[49,50]$. The natural biological process do not need any complex designing as it involves a simple metabolism process. In this case, no need of raising temperature as the biological species grow at the ambient atmospheric conditions. Usually the biological species used in the bioreduction process are indigenous species do not need any extra nutrient for their growth when they are used in the scale up applications [43]. The bioremediation processes are usually single step process and 
rarely do they undergo multiple steps enabling implementation more convenient. All together the bioremediation emerges as a superior to conventional processes.

\subsection{Biological reduction mechanism}

Hexavalent chromium develops intracellular toxicity through a variety of mechanisms including reduction of $\mathrm{Cr}(\mathrm{VI})$ to $\mathrm{Cr}(\mathrm{III})$, generation of reactive species, Cr-DNA complex formation, protein denaturation and electrostatic interactions $[19,47]$. Despite numerous toxicity effects, there are different microbes which have shown a tolerance to $\mathrm{Cr}(\mathrm{VI})$ with concentrations above the standard regulation level. Chromium tolerance has been described in terms of cellular accumulation, extracellular reduction, adsorption, intracellular reduction followed by salt liberation, counter enzyme system and efflux mechanisms [48]. Biological systems lack the ability to re-oxidize $\mathrm{Cr}(\mathrm{III})$ to $\mathrm{Cr}(\mathrm{VI})$. Extracellular reduction of $\mathrm{Cr}(\mathrm{VI})$ is a detoxification process that produces nontoxic $\mathrm{Cr}(\mathrm{III})$ which is unable to pass through the cell membranes. Studies of reduction activities in tissue homogenates and biological fluids showed that ascorbate was the principal biological reducer of $\mathrm{Cr}(\mathrm{VI})$, accounting for $80-95 \%$ of its metabolism [49]. A combined activity of ascorbate with glutathione and cysteine is responsible for $>95 \%$ of $\mathrm{Cr}(\mathrm{VI})$ reduction in vivo. The concentrations of glutathione and ascorbate in the tissues are not usually different, and the predominant role of ascorbate stems from its very high rate of $\mathrm{Cr}(\mathrm{VI})$ reduction. [50] Depending on the nature of the reducing agent, its concentration, and stoichiometry, $\mathrm{Cr}(\mathrm{VI})$ reduction reactions generate variable amounts of transient products such as $\mathrm{Cr}(\mathrm{V}), \mathrm{Cr}(\mathrm{IV})$, and sulfur- and carbon- based radicals. [51] As expected for these important biological antioxidants, glutathione, 
cysteine and ascorbate derived radicals formed in $\mathrm{Cr}(\mathrm{VI})$ reactions are unreactive toward DNA. [52]

Both soluble and membrane-associated enzymes have mediated the process of $\mathrm{Cr}(\mathrm{VI})$ reduction under anaerobic conditions. Cytochromes $\mathrm{b}$ and $\mathrm{c}$ present in the cells are involved in the transportation of an electron within the cells resulting in enzymatic anaerobic $\mathrm{Cr}(\mathrm{VI})$ reduction. [53] Under anaerobic conditions, $\mathrm{Cr}(\mathrm{VI})$ serves as a terminal electron acceptor in the membrane electron-transport respiratory pathway. This process results in energy conservation for growth and cell maintenance where NADH, carbohydrates, proteins, fats, hydrogen, and endogenous electron reserves donate electrons to $\mathrm{Cr}(\mathrm{VI})$. [54] In the aerobic reaction, the $\mathrm{Cr}(\mathrm{VI})$ associates with oxygen and is the sole electron donor system forming different reactive oxygen species within the cell. This formation of reactive oxygen species catalyzes the $\mathrm{Cr}(\mathrm{VI})$ reduction with formation of series of different intermediate of $\mathrm{Cr}(\mathrm{IV})$ and $\mathrm{Cr}(\mathrm{V})$ until finally reduced to $\mathrm{Cr}(\mathrm{III})$. [55] This mechanism is shown in figure 3 .

Indirect chromium reduction occurs in some iron and sulfur reducing bacteria. These groups of microbes produce different metabolites such as $\mathrm{Fe}(\mathrm{II})$ or hydrogen sulphide $\left(\mathrm{H}_{2} \mathrm{~S}\right)$. The reduction of $\mathrm{Cr}(\mathrm{VI})$ by $\mathrm{H}_{2} \mathrm{~S}$ involves three stages: (a) reduction of sulfates, (b) reduction of chromate by sulfides and (c) precipitation of $\mathrm{Cr}(\mathrm{VI})$ by sulfide. [56] The reduction of $\mathrm{Cr}(\mathrm{VI})$ by $\mathrm{Fe}(\mathrm{II})$ occurs when iron reducing bacteria reduces $\mathrm{Fe}(\mathrm{III})$ to $\mathrm{Fe}(\mathrm{II})$, which in turn reduces $\mathrm{Cr}$ (VI) to $\mathrm{Cr}(\mathrm{III})$. $\mathrm{The}$ kinetics of the indirect reduction of chromium in iron and sulfur reducing bacteria is greater than that of direct biological chromium reduction. [57] Once the $\mathrm{Cr}(\mathrm{VI})$ has been reduced to $\mathrm{Cr}(\mathrm{III})$, it accumulates in cells by the formation of coordination complexes with proteins. There are many electron rich proteins produced by microbes in both the intracellular and extracellular 
environments. $\mathrm{Cr}$ (III) favourably forms chelating complexes with proteins, which is the major reason for accumulation of $\mathrm{Cr}(\mathrm{III})$. [58]

Efflux mechanism for chromium resistance bacteria are described by formation of hydrophobic protein $C h r A$ a product of $c h r A$ gene. Chromate tolerance conferred by the ChrA protein was associated with reduced accumulation of $\mathrm{CrO}_{4}{ }^{2-}$ in both $P$. aeruginosa and A. eutrophus. [59] It was hypothesized by Alvarez et al.[59] that ChrA was involved in the extrusion of chromate ions. Branco et al.[60] reported that the highly tolerant strain Ochrobactrum tritici survived chromate concentrations above $50 \mathrm{mM}$ and have the transposon TnOtChr, which contains a group of $C h r B$, ChrA, ChrC and ChrF genes. The genes $C h r B$ and $C h r A$ genes were essential for establishing high resistance in chromium-sensitive $O$. tritici. They also reported that the $C h r$ promoter was strongly induced by chromate or dichromate but was completely unresponsive to $\mathrm{Cr}(\mathrm{III})$, oxidants, sulfate, or other oxyanions. Induction of the $C h r$ operon suppressed accumulation of cellular chromium through the activity of a chromate efflux pump that is encoded by $C h r A$ [60].

Microbial heavy metal biosorption comprises of two phases: an initial rapid phase involving physical adsorption or ion exchange at cell surface and a subsequent slower phase involving active metabolism-dependent transport of heavy metal into the bacterial cells. During bioaccumulation, intracellular sequestration occurs followed by localization within specific organelles, metallothionein binding, particulate metal accumulation, extracellular precipitation and complex formation. [61,62] Biosorption is established as the mechanism of the challenging process to remove pollutants from aqueous medium. Saha and Orvig in 2010 [63] proposed four biosorption mechanisms of chromium; (a) anionic adsorption to cationic functional groups, (b) adsorptioncoupled reduction, (c) anionic and cationic adsorption, and (d) reduction and anionic adsorption. Despite the fact that the mechanisms of metal binding by individual cellular organelles and 
chemical moieties are known, sorption of metals to intact cells and cellular products such as biofilms is governed by a multiplicity of mechanisms and interactions, which are not always fully understood [64].

The cellular phenomena such as cellular accumulation, extracellular reduction, adsorption, intracellular reduction followed by salt liberation, counter enzyme system and efflux mechanisms showed compatibility of direct and indirect bioreduction. [48] The inherent properties of the biomass capable of performing the removal of $\mathrm{Cr}(\mathrm{VI})$ from the water system have been described in the mechanism above. Since biological processes are natural and eco-friendly, the environmental impact assessment has minimum role in the implementation in the pilot scale. Extensive researches are required to standardize the process along with evaluation of its feasibility for implementation in a cost-effective way.

\section{Bioreduction of $\mathrm{Cr}(\mathrm{VI})$}

\subsection{Bacteria}

Microbial Cr(VI) reduction was first reported in the late 1970s. [65] The authors observed a $\mathrm{Cr}(\mathrm{VI})$ reduction capability in Pseudomonas species grown under anaerobic conditions. The active bacterial strain, isolated from sewage sludge, was classified as Pseudomonas dechromaticans. Since then a variety of microorganisms have been identified and isolated from a diverse range of environments with the capacity to remove $\mathrm{Cr}(\mathrm{VI})$ contamination. Several researchers have isolated microorganisms that catalyze the reduction of $\mathrm{Cr}$ (VI) to $\mathrm{Cr}(\mathrm{III})$ under various conditions and experimental design including changes to $\mathrm{pH}$, temperature, degree of agitation, aerobic and anaerobically, initial $\mathrm{Cr}(\mathrm{VI})$ concentration, nutrient supplementation, cell free $\mathrm{Cr}(\mathrm{VI})$ reductase, 
electron shuttle addition, changes to reactor design, cell immobilizers among others. $[6,8,10]$ Bacteria endowed with the capacity to reduce $\mathrm{Cr}(\mathrm{VI})$ levels are named chromium-reducing bacteria (CRB). [66] CRB are generally isolated from industrial effluents, especially those from chromite mines [67], tanneries [68-70], textile industries [71], and electroplating manufacturing [72]. CRB have been isolated from soils contaminated with these effluents. [73-75] A list of isolates presented in table 5 for the reduction of $\mathrm{Cr}(\mathrm{VI})$ from deferent sources with briefly summarized processes.

Leucobacter sp. is a new finding isolated from a chromate-contaminated soil. The Leucobacter $\mathrm{sp}$. showed a distinct and effective $\mathrm{Cr}(\mathrm{VI})$ reduction under aerobic growth conditions, followed by facultative anaerobic incubation for $\mathrm{Cr}(\mathrm{VI})$ reduction. [76] Ten Gram-negative bacteria isolated from a chromium contaminated effluent of industrial landfill were inoculated into Luria Bertani (LB) culture medium containing $100 \mathrm{mg} / \mathrm{L} \mathrm{Cr}(\mathrm{VI})$. But only two bacteria Alcaligenes faecalis and Pseudochrobactrum saccharolyticum showed growth capacity within $48 \mathrm{~h}$ of incubation with minimum inhibitory concentrations (MIC) to Cr(VI) were above $100 \mathrm{mg} / \mathrm{L}$. [77] The experiments were conducted with synthetic $\mathrm{K}_{2} \mathrm{Cr}_{2} \mathrm{O}_{7}$ solution in $\mathrm{LB}$ media as well as industrial effluents without LB media at two sets of $\mathrm{Cr}(\mathrm{VI})$ concentration such as 10 and $100 \mathrm{mg} / \mathrm{L}$. In the culture medium containing $10 \mathrm{mg} / \mathrm{L} \mathrm{Cr}(\mathrm{VI})$ concentration, $100 \%$ chromium removal was achieved in $48 \mathrm{~h}$ for both the isolates. A. faecalis showed an easy log phase after inoculation compared to $P$. saccharolyticum. At $\mathrm{Cr}(\mathrm{VI})$ concentrations of $100 \mathrm{mg} / \mathrm{L}$, A. faecalis reduced $70 \%$ of $\mathrm{Cr}(\mathrm{VI})$ in 120 $\mathrm{h}$ of incubation with a log phase from 24 to $48 \mathrm{~h}$. In the same medium, $P$. saccharolyticum achieved high cell concentration after $48 \mathrm{~h}$ of incubation but did not reduce $\mathrm{Cr}(\mathrm{VI})$ further. $P$. saccharolyticum reduced only $45 \%$ during incubation period of 72 to $120 \mathrm{~h}$. Both the isolates showed $24 \mathrm{~h}$ as lag period in culture medium of $100 \mathrm{mg} / \mathrm{L} \mathrm{Cr}(\mathrm{VI})$. In the industrial effluent without 
additional nutrients, no reduction was observed for the either isolates. When nutrients in the form of carbon, nitrogen, and phosphorous were added to the effluent, both the isolates showed complete reduction of $\mathrm{Cr}(\mathrm{VI})$ in $72 \mathrm{~h}$ of incubation. This implied that nutrients are a limiting factor for the reduction of $\mathrm{Cr}(\mathrm{VI})$. These nutrients worked as the electron donor to reduce $\mathrm{Cr}(\mathrm{VI})$ to $\mathrm{Cr}(\mathrm{III})$. [78] The effect of temperature is shown by the efficiency of reduction at $30^{\circ} \mathrm{C}$ for $72 \mathrm{~h}$ was similar to that at $10^{\circ} \mathrm{C}$ for $144 \mathrm{~h}$. At low temperatures, the fluidity of the membrane decreases sufficiently to prevent the functioning of the transport systems, so substrates cannot enter the cell as rapidly, causing a low growth rate. [79] At an optimum temperature, the bacterium could utilize the substrate better, in consonance with other optimum cultural and nutritional conditions. Furthermore, temperature is known to affect the stability of microbial cell wall, its configuration, and can cause ionization of chemical moieties. [80] Isolated Pseudomonas mendocina used to study the chromium reduction with variation of $\mathrm{pH}$, initial chromium concentrations, organic acids (alginic acid, galacturonic acid, glucuronic acid and citric acid) and their binary combinations. [81] The $\mathrm{Cr}(\mathrm{VI})$ reduction rate decreased with the increase in initial chromium concentration at optimum $\mathrm{pH}$ 6.0. The $\mathrm{Cr}(\mathrm{VI})$ reduction was increased in the presence of organic acids and the combination of galactronic acid and glucuronic acid showed more effective. Desorption indicated the removal of $\mathrm{Cr}(\mathrm{VI})$ due to reduction reaction instead of biosorption. [81] Similar works report using different isolated strains with variation of $\mathrm{pH}$, temperature and initial concentration of $\mathrm{Cr}(\mathrm{VI})$ [82,83].

Acenetobacter calcoaciticus, a lyophilized Gram negative bacterium, was isolated from water sample taken from the Sukinda mine area of Jajpur Odisha, India. Since unfavorable pH may retard cell growth and hinder the enzymatic activity, it is an important factor in achieving the efficient $\mathrm{Cr}(\mathrm{VI})$ reduction. The reduction of $\mathrm{Cr}(\mathrm{VI})$ is highly $\mathrm{pH}$ dependent because protons are 
significantly involved in the reduction mechanism. For a $\mathrm{Cr}(\mathrm{VI})$ reduction study A. calcoaciticus was grown in $\mathrm{LB}$ broth medium containing $100 \mathrm{mg} / \mathrm{L} \mathrm{Cr}(\mathrm{VI})$ varying $\mathrm{pH}$ at temperature $30{ }^{\circ} \mathrm{C}$ and speed $100 \mathrm{rpm}$. The optimum $\mathrm{pH}$ was determined to be 8.0 where $A$. calcoaciticus reduced $85 \%$ Cr(VI) in 24 h. [84] Pseudochrobactrum saccharolyticum was grown in a modified LB media starting at $\mathrm{pH} 7.0$ with other variable conditions. At optimum conditions of $\mathrm{pH} 8.3$, initial $\mathrm{Cr}(\mathrm{VI})$ $55 \mathrm{mg} / \mathrm{L}, \mathrm{NaCl} 20 \mathrm{mg} / \mathrm{L}$, and $1.47 \times 10^{9}$ cells/mL showed a complete reduction within $96 \mathrm{~h}$. Electron microscopy like TEM and EDS analysis of the biomass revealed irregular and loss of shape of the cell on exposure to $\mathrm{Cr}(\mathrm{VI})$ with significant precipitation of $\mathrm{Cr}(\mathrm{III})$ both on and inside the cells. X-ray absorption spectroscopy (XAS) studies of the chromium treated bacterial cell showed a clear reduction of $\mathrm{Cr}(\mathrm{VI})$ to $\mathrm{Cr}(\mathrm{III})$. Microorganisms requiring salt for growth are referred as halophiles. Since sodium is an essential element for the ionic pumps in halophiles, the reduction rate increased with increase of $\mathrm{NaCl}$ up to $20 \mathrm{~g} / \mathrm{L}$ [85].

Another halophile was found to be Halomonas species isolated from tannery effluent was able to reduce $82 \%$ of $50 \mathrm{mg} / \mathrm{L} \mathrm{Cr}(\mathrm{VI})$ in $48 \mathrm{~h}$. The reduction of $\mathrm{Cr}(\mathrm{VI})$ in the concomitant was visualized by discolouring of yellow colour of the medium and formation of insoluble precipitate. It showed an excellent $\mathrm{MIC}$ at $3500 \mathrm{mg} / \mathrm{L} \mathrm{Cr}(\mathrm{VI})$ when $20 \% \mathrm{NaCl}$ was added to the media. It favored strong $\mathrm{Cr}(\mathrm{VI})$ reduction under alkaline condition at $\mathrm{pH}$ 10.0. Scanning electron microscopy (SEM) analysis revealed insoluble precipitate of $\mathrm{Cr}$ (III) on bacterial cell surfaces further confirmed as $\mathrm{Cr}(\mathrm{OH})_{3}$ by EDS analysis $[86,87]$. Similar halotolerant and toxic heavy metals tolerant tannery effluent isolate Staphylococcus arlettae strain could tolerate Cr(VI) up to 2000 and $5000 \mathrm{mg} / \mathrm{L}$ in liquid and solid media respectively, and reduced $98 \%$ and $75 \%$ with initial $\mathrm{Cr}(\mathrm{VI})$ concentrations of 500 and $1000 \mathrm{mg} / \mathrm{L}$, respectively in $120 \mathrm{~h}$ [88]. 
Corynebacterium is a Gram-positive bacterium species showed resistant to high concentrations of chromate with an MIC of $22 \mathrm{mM}$ [89]. A multi-metal tolerant bacteria Corynebacterium paurometabolum isolated from chromite mine drainage was used to evaluate chromium reduction ability in $2 \mathrm{mM} \mathrm{Cr}(\mathrm{VI})$ in Vogel Bonner broth. The $C$. paurometabolum could reduce $62.5 \%$ of $\mathrm{Cr}(\mathrm{VI})$ in 8 days of incubation with no green precipitate of $\mathrm{Cr}(\mathrm{III})$ at $\mathrm{pH}$ 7.0. Presence of different cations ( $\mathrm{Zn}(\mathrm{II}), \mathrm{Cd}(\mathrm{II}), \mathrm{Cu}(\mathrm{II}), \mathrm{Ni}(\mathrm{II})$ ), anions (nitrate, phosphate, sulphate, and sulphite) and compounds (sodium fluoride, carbonyl cyanide m-chlorophenyl hydrazone, sodium azide, NN-Di cyclohexyl carboiimide) played an inhibitory effect on the reduction. Temperature showed worsening efficiency below $20^{\circ} \mathrm{C}$ and above $40^{\circ} \mathrm{C}$ with maximum efficiency at $35^{\circ} \mathrm{C}$. The carbon source was found to be a limiting factor as reduction is positively influenced by glucose and glycerol as these mimic the cellular membrane [90].

The feather-degrading Stenotrophomonas maltophilia produces a keratinolytic enzyme using chicken feathers as the sole carbon and nitrogen source. Addition of small amount of glucose and poly peptone to the feather medium increases the enzyme production [91,92]. A novel featherdegrading S. maltophilia was isolated from feather disposal site for chromium reduction study. It reduced $78 \%$ and $63 \%$ from solutions containing 50 and $100 \mathrm{mg} / \mathrm{L} \mathrm{Cr}(\mathrm{VI})$ respectively in $1 \mathrm{~h}$. There was no reduction of $\mathrm{Cr}(\mathrm{VI})$ when autoclaved feather protein hydrolysate was used. This shows that bacterial enzymes were not involved in the reduction process directly. The reduction was due to direct reduction of $\mathrm{Cr}(\mathrm{VI})$ by $S$. maltophilia where feather protein hydrolysate from the chicken feathers were electron donors. Cr(VI) reduction was significantly inhibited by mercury ions $(\mathrm{Hg}(\mathrm{II}))$ indicating the role of sulfur-containing amino acids in reduction process. FTIR analysis confirmed that chromium reduction occurred due to oxidation of amino acids such as cysteine and cystine [93]. 
Gram-negative bacteria Acinetobacter belongs to the wider class of Gamma-proteobacteria and has been employed for $\mathrm{Cr}(\mathrm{VI})$ reduction. It is a bacterium tolerant to many metals and oxygen demanding pollutants. One isolate of Acinetobacter sp. from aerator water of an activated sludge process at a dye and pigment industry exhibited high tolerance capacity for up to $1,100 \mathrm{mg} / \mathrm{L}$ of $\mathrm{Cr}(\mathrm{VI})$ and showed efficient chromium reduction. This Acinetobacter sp. was found to be very efficient and tolerant to several other metal ions in addition to $\mathrm{Cr}(\mathrm{VI})$. The MICs of this bacteria were $800,700,350,600,1100$, and $1000 \mathrm{mg} / \mathrm{L}$ towards different heavy metal ions such as $\mathrm{Ni}(\mathrm{II})$, $\mathrm{Zn}(\mathrm{II}), \mathrm{Cd}(\mathrm{II}), \mathrm{Cu}(\mathrm{II}), \mathrm{Pb}(\mathrm{II})$, and $\mathrm{Fe}(\mathrm{III})$, respectively [94]. Another isolate of the species Acinetobacter haemolyticus favoured $\mathrm{Cr}(\mathrm{VI})$ reduction at the lower concentrations ranging 10 to $30 \mathrm{mg} / \mathrm{L}$, however, incomplete $\mathrm{Cr}(\mathrm{VI})$ reduction occurred at concentrations ranging 70 to 100 $\mathrm{mg} / \mathrm{L}$. Initial specific reduction rate increased with $\mathrm{Cr}(\mathrm{VI})$ concentrations. $\mathrm{Cr}(\mathrm{VI})$ reduction was not affected by 1 to $10 \mathrm{mM}$ sodium azide (a metabolic inhibitor), $10 \mathrm{mM}$ of $\mathrm{PO}_{4}{ }^{3-}, \mathrm{SO}_{4}{ }^{2-}, \mathrm{SO}_{3}{ }^{2-}$, $\mathrm{NO}_{3}{ }^{-}$or $30 \mathrm{mg} / \mathrm{L}$ of $\mathrm{Pb}(\mathrm{II}), \mathrm{Zn}(\mathrm{II}), \mathrm{Cd}(\mathrm{II})$ ions. The TEM analysis revealed A. haemolyticus cells had lost its shape and size after exposure to 10 to $50 \mathrm{mg} / \mathrm{L} \mathrm{Cr}(\mathrm{VI})$. The presence of electron-dense particles in the cytoplasmic region of the bacteria suggested deposition of chromium in the cells [95]. In another study the $\mathrm{Cr}(\mathrm{VI})$ reduction by an Acinetobacter sp. showed high tolerance up to $1100 \mathrm{mg} / \mathrm{L}$ and high $\mathrm{Cr}(\mathrm{VI})$ reducing capacity. The $\mathrm{Cr}(\mathrm{VI})$ reduction rates decreased in presence of $\mathrm{Ni}(\mathrm{II}), \mathrm{Zn}(\mathrm{II})$ and $\mathrm{Cd}(\mathrm{II})$. The lead ion $\mathrm{Pb}(\mathrm{II})$ did not show significant effect at lower concentration while $\mathrm{Cu}(\mathrm{II})$ and $\mathrm{Fe}(\mathrm{III})$ stimulated the rate of $\mathrm{Cr}(\mathrm{VI})$ reduction. The inhibiting effect of ions $\mathrm{Ni}(\mathrm{II}), \mathrm{Zn}(\mathrm{II}), \mathrm{Pb}(\mathrm{II})$ and $\mathrm{Cd}(\mathrm{II})$ decreased in the presence of $\mathrm{Cu}(\mathrm{II})$ and $\mathrm{Fe}(\mathrm{III})$ ions during Cr(VI) reduction in the multi-metal ions solution [96].

Gram positive bacteria Actinomycetes exhibit many interesting activities such as degradation and transformation of organic and metal substrates together with the production of antibiotics. 
Traditionally, Actinomycetes have been a rich source of biotechnological products like antibiotics, industrial enzymes and other bioactive molecules [97]. Different Gram positive bacteria such as Actinomycetes, Cellulosimicrobium sp., and Exiguobacterium sp. were isolated from different chromium contaminated sites to study the efficacy of $\mathrm{Cr}(\mathrm{VI})$ reduction. One Actinomycetes isolate was found to reduce $82.6 \%$ and $44.3 \%$ at initial $\mathrm{Cr}(\mathrm{VI})$ concentrations of $2.5 \mathrm{mM}$ and $5 \mathrm{mM}$, respectively, within $72 \mathrm{~h}$ of incubation [98]. However, Cellulosimicrobium sp., and Exiguobacterium sp. with MICs of 250 and $100 \mathrm{mM}$, respectively, reduced $45 \%$ of $\mathrm{Cr}(\mathrm{VI})$ in DeLeo and Ehrlich medium containing $10 \mathrm{mM} \mathrm{Cr(VI)} \mathrm{[99].} \mathrm{One} \mathrm{aerobic} \mathrm{bacterium} \mathrm{Sporosarcina}$ saromensis among fifty-five strains isolated from intertidal zones at low tide showed a MIC of $\mathrm{Cr}(\mathrm{VI}) 500 \mathrm{mg} / \mathrm{L}$ in $216 \mathrm{LB}$ medium. The $S$. saromensis could completely reduce $100 \mathrm{mg} / \mathrm{L} \mathrm{Cr}(\mathrm{VI})$ at $\mathrm{pH} 8.0$ and $35^{\circ} \mathrm{C}$ in 24 h. [100] Field et al. [101] used Cellulomonas species to assess the influence of various carbon sources, iron minerals, and electron shuttling compounds on $\mathrm{Cr}(\mathrm{VI})$ reduction. Results indicated the influence of the type of carbon source as well as electron shuttle on $\mathrm{Cr}(\mathrm{VI})$ reduction rate. The molasses as carbon source stimulated $\mathrm{Cr}(\mathrm{VI})$ reduction more effectively than pure sucrose, due to presence of more easily utilizable sugars. The $\mathrm{Cr}(\mathrm{VI})$ reduction rate increased with increasing concentration of electron shuttling compound anthraquinone-2,6-disulfonate regardless of the carbon source.

The $\mathrm{Cr}(\mathrm{VI})$ reduction potential of Escherichia coli was significant as it reduced $95 \%$ within $24 \mathrm{~h}$ when experimental parameters including $\mathrm{pH}$, temperature, $\mathrm{Fe}(\mathrm{III})$ dosage, carbon source, and chelating agent, were optimized [102]. The pH-5.8 and temperature $32^{\circ} \mathrm{C}$ were found to be best condition when the culture medium was amended with $\mathrm{Fe}(\mathrm{III})$ and sodium citrate. The Fe(III) enhanced the reduction process by shuttling electrons from bio-reduced $\mathrm{Fe}$ (II) to $\mathrm{Cr}(\mathrm{VI})$ in a 
coupled biotic-abiotic cycle. The addition of chelating agent sodium salt of EDTA inhibited the process.

Alkaliphilic Gram-positive bacteria Bacillus firmus shows potential to reduce $\mathrm{Cr}(\mathrm{VI})$ in vitro conditions [104]. The chromium reductase of Bacillus species was used to reduce $\mathrm{Cr}(\mathrm{VI})$ with NADH supplement as electron donor [210]. An isolated bacterium Bacillus subtilis could reduce $\mathrm{Cr}(\mathrm{VI})$ to $\mathrm{Cr}(\mathrm{III})$ at $\mathrm{pH}$ of 9.0 and initial concentration of $\mathrm{Cr}(\mathrm{VI})$ at $50 \mathrm{mg} / \mathrm{L}$ [105]. Another highly chromate-resistant Bacillus cereus showed MICs of 1300, 1450 and 1050 in nutrient broth, LB broth and mineral salt media, respectively. It reduced $57 \%$ within $24 \mathrm{~h}$ of incubation and up to $70 \%$ in further $24 \mathrm{~h}$, when initial Cr(VI) concentration was 100mg/L [106]. In another study B.cereus reduced 73 and $92 \%$ of $\mathrm{Cr}(\mathrm{VI})$ from tannery effluent with free cells and immobilized cells respectively, at temperature $35^{\circ} \mathrm{C}$ and $120 \mathrm{rpm}$ in $48 \mathrm{~h}$ [107]. An improvement in mitotic index and reduction in chromosomal aberrations was also observed in A. cepa grown with posttreatment effluent samples compared to untreated sample. In a bioreactor a Bacillus sp. was used for $\mathrm{Cr}(\mathrm{VI})$ reduction varying conditions like immobilized cells, cell free enzyme extracts, flow rate and initial $\mathrm{Cr}(\mathrm{VI})$ concentration. For immobilized cells different immobilizers such as celite, amberlite and Ca-alginate were added in to the media. With the initial $\mathrm{Cr}(\mathrm{VI})$ concentrations of 2 to $8 \mathrm{mg} / \mathrm{L}$ at the flow rates of 3 to $6 \mathrm{~mL} / \mathrm{hr}$, the immobilized cells and cell free extracts reduced $84 \%$ and $98 \%$ respectively, in the presence of celite and Ca-alginate [103].

The advantage of extracellular chromate reductase of the chromium reducing bacteria (CRB) is that it can be used under different environmental conditions, especially mining waste water. Cell free chromate reductase enzyme from a CRB Arthrobacter was used to determine the reduction efficiency. The enzyme was unaffected to different metals such as $\mathrm{Mn}(\mathrm{II}), \mathrm{Mg}$ (II) and $\mathrm{Fe}(\mathrm{III})$ present in a water sample of chromite mine seepage. The $\mathrm{Cr}(\mathrm{VI})$ reducing activity of the reductase 
enzyme was maximized at $\mathrm{pH}$ range 6.5 to 7.5 and at a temperature of $35^{\circ} \mathrm{C}$, and was dependent on NADH [108,109]. A laboratory CRB culture A. viscosus was used remove $\mathrm{Cr}(\mathrm{VI})$. The experiments were conducted with both dead and live biomasses in a batch study and live biomass in a column study. From the $\mathrm{pH}$ variation data, $\mathrm{pH}$ at 1.0 favoured the $\mathrm{Cr}(\mathrm{VI})$ reduction but $\mathrm{pH} 2.0$ favoured the total chromium removal in both the dead and live biomass. Contact time favoured the application of live biomass. For the column experiment, a pre-grown culture of A. viscosus was pumped in to the column in an up-flow method with a flow rate of $19 \mathrm{~mL} / \mathrm{min}$ for $120 \mathrm{hrs}$ to form a visible biofilm inside the column. Then solution containing $25 \mathrm{mg} / \mathrm{L} \mathrm{Cr}(\mathrm{VI})$ at $\mathrm{pH} 2.0$ was passed through same up-flow method at a flow rate of $10 \mathrm{~mL} / \mathrm{min}$ continuously in ambient condition. The equilibrium of chromium uptake was achieved in $7.5 \mathrm{~h}$ with uptake of $20.3 \mathrm{mg}$ per one gram of biofilm [110].

Desulfovibrio vulgaris Hildenborough is a model sulfur reducing bacteria (SRB) and has been shown to reduce metals, metalloids, and radionuclides [111]. The cell-mediated reduction using SRB involves hydrogenases and cytochrome $\mathrm{c}(3)$ as well as reduction by hydrogen sulfide. [112] D. vulgaris Hildenborough is capable of reducing $\mathrm{Cr}(\mathrm{VI})$, but cells are unable to use $\mathrm{Cr}(\mathrm{VI})$ as a terminal electron acceptor linked to growth. [113] D. vulgaris strain was used to study the $\mathrm{Cr}(\mathrm{VI})$ reduction ability in the presence of the Fe-bearing minerals hematite, aluminum substituted goethite (Al-goethite), and nontronite (NAu-2). Also an abiotic $\mathrm{Cr}(\mathrm{VI})$ reduction was conducted in dithionite reduced NAu-2 or iron sulfide (FeS). The pseudo first order reduction of $\mathrm{Cr}(\mathrm{VI})$ was observed in microcosms containing D. vulgaris strain and hematite/Al-goethite, and the rate constant was found to be $1.49 \mathrm{hr}^{-1}$. The microcosms containing only D. vulgaris strain without hematite pseudo first order rate constant was $0.56 \mathrm{hr}^{-1}$. But the combination of NAu-2 and microcosms containing D. vulgaris strain showed decreased reduction due to toxicity of high 
concentration of $\mathrm{Al}(\mathrm{III})$ present in the mineral aid. There was significant initial loss of $\mathrm{Cr}(\mathrm{VI})$ in mineral aid due to adsorption, and significant $\mathrm{Cr}(\mathrm{VI})$ instead of $\mathrm{Cr}(\mathrm{III})$ was found in the resulting solids. [114] In another study D. vulgaris showed lag period of approximately $30 \mathrm{~h}$ in presence of $0.05 \mathrm{mM} \mathrm{Cr}(\mathrm{VI})$, though $\mathrm{Cr}(\mathrm{VI})$ was reduced within the first $5 \mathrm{~h}$ without growth of the strain [115]. During the lag period small amounts of lactate were still utilized without sulfate reduction or acetate formation. After $40 \mathrm{~h}$ of incubation sulfate reduction occurred concurrently with the accumulation of acetate and production of hydrogen due to bacterial activity. The lag period was prevented by addition of ascorbate to $\mathrm{Cr}(\mathrm{VI})$ exposed $D$. vulgaris culture medium. Addition of pyruvate displayed more tolerance to $\mathrm{Cr}(\mathrm{VI})$ exposed $D$. vulgaris culture medium compared to lactate.

Co-existence of the different toxic metals is common in high temperature environments (up to 70 $\left.{ }^{\circ} \mathrm{C}\right)$. Results Thermophiles have potential application in metal bioremediation at high temperature subsurface radioactive waste disposal sites, effluents from refractory and metallurgical industries and other high temperature wastes. Despite significant progress on iron reduction by thermophilic microorganisms, studies on the ability of these bacteria to reduce toxic metals are still limited. Deinococcus geothermalis, a radiation-resistant thermophilic bacterium and Bacillus thermoamylovorans, a moderately thermophilic and facultative anaerobic bacterium have showed $\mathrm{Cr}(\mathrm{VI})$ reduction ability $[116,117]$. Thermophilic methanogen obligate Methanothermobacter thermautotrophicus was used to reduce $\mathrm{Cr}(\mathrm{VI})$ with $\mathrm{H}_{2} / \mathrm{CO}_{2}$ as substrate containing various $\mathrm{Cr}(\mathrm{VI})$ concentrations ranging from 0.2 to $5 \mathrm{mM}$. The thermophile $M$. thermautotrophicus showed complete reduction up to $0.4 \mathrm{mM} \mathrm{Cr}(\mathrm{VI})$. SEM and TEM analysis of $M$. thermautotrophicus cells after $\mathrm{Cr}(\mathrm{VI})$ exposure found both extra- and intracellular chromium reduction mechanisms [118]. 


\subsection{Fungi}

Fungi have unique properties which sustain them in toxic metal contaminated sites due the presence of cell wall material within that shows excellent metal-binding properties. The enzymemediated activity of fungi provides sufficient metabolites to treat wastewaters. The enzymes are produced during all phases of the fungal life cycle unlike bacteria and irrespective of pollutant concentrations [119]. In addition to extracellular enzyme production, fungal biomass has been identified as a most effective adsorbent for accumulation of toxic metals, such as $\mathrm{Cr}, \mathrm{Cu}, \mathrm{Hg}, \mathrm{Ni}$, $\mathrm{Cd}$ and $\mathrm{Pb}$, from wastewaters $[120,121]$. Fungi species are known to detoxify toxic metals by several mechanisms including extra and intra cellular precipitation, redox reaction and active uptake [122-124] Different metabolic products of fungi like phosphate, proteins, and nitrogencontaining ligands on protein, chitin and chitosan also influence the toxic metal uptake $[125,126]$. The fungi can adapt and grow under high metal concentrations and in various extreme conditions of temperature, nutrient availability and $\mathrm{pH}$. [127] A chromium resistant fungal strain Fusarium isolated from the contaminated soil of a tannery effluent was used for a $\mathrm{Cr}(\mathrm{VI})$ reduction study. [70] The isolated fungal strain reduced all $\mathrm{Cr}(\mathrm{VI})$ at an optimum condition of temperature $25^{\circ} \mathrm{C}$, incubation time $72 \mathrm{~h}$ and $\mathrm{pH}$ 5.0. Protein expression profile showed exposure of the fungal cell to chromium. Different micro imaging analyses revealed enhanced surface roughness, significant swelling and formation of cage like structures on the cell surface induced by $\mathrm{Cr}(\mathrm{VI})$.

Another study, five out of the twenty fungal strains (Penicillium commune, Paecilomyces lilacinus, Cladosporium perangustum, Cladosporium perangustum and Fusarium equiseti) isolated from soil, sludge and wastewater samples of a tannery industry area showed high $\mathrm{Cr}(\mathrm{VI})$ tolerance with MIC above $500 \mathrm{mg} / \mathrm{L}$. Consortium of the five fungal strains were inoculated in a $1 \mathrm{~L}$ bioreactor with supplement of $1 \%$ glucose and $0.01 \%$ ammonium nitrate to remove chromium from the 
tannery wastewater sample containing $\mathrm{Cr}(\mathrm{VI}) 9.86 \mathrm{mg} / \mathrm{L}$ and total chromium $12.26 \mathrm{mg} / \mathrm{L}$. The fungal consortium removed $73 \%$ of $\mathrm{Cr}(\mathrm{VI})$ from the wastewater sample in $12 \mathrm{~h}$ [75]. Various fungal strains of Aspergillus such as A.niger, A.flavus, A.fumigatus, A.nidulans, A.heteromorphus, A.foetidus, and A.viridinutans isolated from different contaminated soil samples of a tannery industry wastewater were used individually for $\mathrm{Cr}(\mathrm{VI})$ removal from wastewater from the same industry. With the conditions of $\mathrm{pH} 3.0$, fungi biomass $4 \mathrm{~g}$ and initial $\mathrm{Cr}(\mathrm{VI})$ concentration 18.1 $\mathrm{mg} / \mathrm{L}$ the order of $\mathrm{Cr}(\mathrm{VI})$ removal efficiency of the individual strain was as: A. niger $>$ A. flavus $>$ A. umigates $>$ A. nidulans $>A$. heteromorphus $>$ A. foetidus $>$ A. viridinutans. A. niger removed a maximum of $96.3 \%$ of $\mathrm{Cr}(\mathrm{VI})$. The MIC of the fungal strains followed a same order of $\mathrm{Cr}(\mathrm{VI})$ removal efficiency [128]. Singh et al. [129] used A. flavus for $\mathrm{Cr}(\mathrm{VI})$ reduction from simulated wastewater with $\mathrm{Fe}$ (II) ion supplement. The $\mathrm{Fe}$ (II) addition significantly enhanced both chromium removal as well as stickiness of the biomaterial. A fungal consortium of A.lentulus, A.terreus and Rhizopus oryzae were used for removal of two heavy metal ions ( $\mathrm{Cr}(\mathrm{VI})$ and $\mathrm{Cu}(\mathrm{II}))$, and two dyes (acid blue 161 and pigment orange 34) from a mixed waste stream. A. terreus alone proved better at $\mathrm{Cr}(\mathrm{VI})$ removal. The mixed consortium removed $100 \% \mathrm{Cr}(\mathrm{VI})$ which was higher than that achieved individually. The complexity of metal-dye mixtures observed in the individual fungus run, but performance of the mixed consortium was unaltered [130].

\subsection{Phyto species}

Biotechnology is drifting towards phytoremediation for cleaning up contaminants. Plants have ability to uptake soluble metal ions from water and soil moisture during photosynthesis $[131,132]$. In addition to the up-taking of metal ions, plants have ability to detoxify metals to less harmful 
forms, either by chelating heavy metals or changing oxidation states [133]. The phytoremediation process is more challenging than its first appear because choosing a plant species for a particular environment is the most important factor and can be difficult. Plants are very sensitive toward toxic metals due to their selectivity towards different metals. Plants depend on properties of ecosystem in terms of the rate of biomass production [134]. Three plant species such as Phragmites australis, Salix viminalis and Ailanthus altissima were irrigated by contaminated water containing $10 \mathrm{mg} / \mathrm{L} \mathrm{Cr}(\mathrm{VI})$ in a continuous process for 360 days to evaluate the chromium reduction efficiency. P.australis and S.viminalis removed $56 \%$ and $70 \%$ of total chromium from water, respectively. However, the efficiency of A.altissima was not significant. The contaminated dry soil analysis revealed the removal efficiency from the soil with initial chromium concentration of 70 $\mathrm{mg} / \mathrm{kg}$ to 32,36 , and $41 \mathrm{mg} / \mathrm{kg}$ for S.viminalis, P.australis, and A.altissima, respectively. The mechanism of chromium removal was confirmed on the basis of reduction of $\mathrm{Cr}(\mathrm{VI})$ as adequate $\mathrm{Cr}(\mathrm{III})$ found in all plant tissues. Highest chromium translocation potential of P.australis and S.viminalis was found respectively from roots to stems and roots to leaves. Of the three plant species Salix can withstand with higher chromium concentration $[135,136]$. In another study Halimione portulacoides was planted to uptake and reduce $\mathrm{Cr}(\mathrm{VI})$. The anti-oxidative feedback and biomarkers were studied using hydroponics mesocosmos approach. H.portulacoides could reduce $40 \% \mathrm{Cr}(\mathrm{VI})$ from the medium containing $15 \mathrm{mg} / \mathrm{L}$ initial concentration, however, the reduction efficiency increased to $60 \%$ when initial $\mathrm{Cr}(\mathrm{VI})$ concentration was $30 \mathrm{mg} / \mathrm{L}$. The $\mathrm{Cr}(\mathrm{VI})$ was accumulated in the roots and aboveground organs of the plant. Chromium in the chlorophyll and flavonoid proved consequences in the photosynthetic and photo-protective mechanisms [137].The biomass of aquatic plant Hydrilla verticillata is known as a hyper accumulator of toxic metals like $\mathrm{Hg}, \mathrm{Cd}, \mathrm{Cr}$ and $\mathrm{Pb}$ [138]. Biosorption potential of Fenton modified dried biomass 
(FMB) of H.verticillata was investigated to remove $\mathrm{Cr}(\mathrm{VI})$ and $\mathrm{Ni}(\mathrm{II})$ ions from wastewater using an up-flow packed-bed column reactor. Within the optimized design parameters of the column reactor such as bed height of $25 \mathrm{~cm}$, flow rate $10 \mathrm{~mL} / \mathrm{min}$, initial metal ion concentration $5 \mathrm{mg} / \mathrm{L}$ and particle size range of FMB 0.25 to $0.50 \mathrm{~mm}$, the biosorption efficiencies for $\mathrm{Cr}(\mathrm{VI})$ and $\mathrm{Ni}(\mathrm{II})$ uptake were 89 and $87 \mathrm{mg} / \mathrm{g}$, respectively. Column regeneration experiments using $0.1 \mathrm{M} \mathrm{HNO}_{3}$ showed good reusability of FMB for ten cycles of sorption and desorption. [139] Dried twigs of Melaleuca diosmifolia fallen from the plants were used to detoxify and remove $\mathrm{Cr}(\mathrm{VI})$ from aqueous solution. The gas chromatography of dried twigs revealed the presence of natural sources of eucalyptol which contained high concentrations of reducing compounds like iron, phenols and flavonoids. Batch studies revealed $5 \mathrm{~g} / \mathrm{L}$ of dried twigs able to remove 97 to $99.9 \% \mathrm{Cr}(\mathrm{VI})$ from the solution containing $250 \mathrm{mg} / \mathrm{L}$ when the $\mathrm{pH}$ ranged from 2 to 10 and temperature from $24^{\circ} \mathrm{C}$ to $48^{\circ} \mathrm{C}$. From the well fitted Langmuir adsorption isotherm the monolayer adsorption capacity was $62.5 \mathrm{mg} / \mathrm{g}$. The inductively coupled plasma optical emission spectrometry and liquid chromatography analyses of the aqueous and solid phases revealed an adsorption-coupled reduction mechanism of $\mathrm{Cr}(\mathrm{VI})$. Further SEM, IR and XRD analyses of the biosorbent before and after adsorption process also confirmed reduction of $\mathrm{Cr}(\mathrm{VI})$ to $\mathrm{Cr}(\mathrm{III})$ followed by complexation onto functional groups of the active surface. The removal efficiency of $\mathrm{Cr}(\mathrm{VI})$ was $99 \%$ from lake and sea water samples. [140]

\subsection{Algae}

Photochemical reduction of $\mathrm{Cr}(\mathrm{VI})$ is a regular practice for remediation of toxic chromium components from the environment. Biomass of algae species Chlorella vulgaris has shown 
efficiency toward $\mathrm{Cr}(\mathrm{VI})$ reduction. This has encouraged interest in employing algal community to reduce the toxic $\mathrm{Cr}(\mathrm{VI})$ from contaminated water and soil. Several efforts have been made to reduce $\mathrm{Cr}(\mathrm{VI})$ into less toxic $\mathrm{Cr}$ (III) by algae as it is available conveniently and less expensively. [141,142] A laboratory salt tolerant microalgae C.vulgaris grown in algal culture medium was used to remove different pollutants in tannery wastewater with 1:1 dilution with tap water. The tannery wastewater contained $3.22 \mathrm{mg} / \mathrm{L} \mathrm{Cr}(\mathrm{VI})$ along with other pollutants. At $28{ }^{\circ} \mathrm{C}$ under fluorescent lights of $150-300 \mu \mathrm{mol}$ photons $/ \mathrm{m}^{2} / \mathrm{s}$, the microalgae completely removed $\mathrm{Cr}(\mathrm{VI})$ from the diluted water sample in 12 days. [143] However, the functional role of organelle inside the algal cell for $\mathrm{Cr}$ (VI) reduction was poorly understood. Chen et al. [144] extracted organelles in green algae C.vulgaris and further treated for $\mathrm{Cr}(\mathrm{VI})$ reduction tests. They observed chloroplasts not only adsorbed $21 \%$ of total chromium but also reduced $70 \%$ of $\mathrm{Cr}(\mathrm{VI})$ in comparison to the abiotic control run. Further the isolated thylakoid membrane showed better $\mathrm{Cr}(\mathrm{VI})$ reduction potential with the presence of sodium alginate, even though the Hill reaction activity was inhibited. As per photosystem II, the addition of mesoporous silica (SBA-15) enhanced the reduction ability through improving the light-harvesting complex II efficiency and electron transport rate. The organelles of $C$. vulgaris not only offered a basement to mechanism of the $\mathrm{Cr}$ (VI) reduction, but also provide a new sight for removal of heavy metals from contaminated water. [144]

Macro-alga Sargassum cymosum has been used as an electron donor for the reduction of Cr(VI). It was used sequentially through the oxidation of the biomass initially followed by as a natural cation exchanger for the chromium sequestration. [145] S. cymosum reduced $3.0 \mathrm{mM}$ of $\mathrm{Cr}(\mathrm{VI})$ while dosed with $1 \mathrm{~g}$ of biomass. The FTIR analysis and potentiometric titration techniques revealed association of weak acidic carboxylic groups on the surface of the biomass as the main mechanism of the sequestration of $\mathrm{Cr}(\mathrm{III})$. The binding sites on the surface of biomass were formed 
due to the oxidation of biomass during $\mathrm{Cr}(\mathrm{VI})$ reduction. In another study, brown macro alga Pelvetia canaliculata was used as a natural electron donor for the reduction of $\mathrm{Cr}(\mathrm{VI})$ from acidic electroplating wastewater. The $\mathrm{Cr}(\mathrm{VI})$ reduction capacities of raw and protonated $P$. canaliculata were found to be 1.8 and $2.3 \mathrm{mmol} / \mathrm{g}$, respectively. The $\mathrm{Cr}(\mathrm{III})$ uptake capacities of the oxidized biomass were 0.8 and $1.9 \mathrm{mmol} / \mathrm{g}$, respectively. In the continuous column reactor packed with raw P. canaliculata, $2.1 \mathrm{mmol} / \mathrm{g} \mathrm{Cr}(\mathrm{VI})$ was reduced. [146]

\subsection{Plant nuts}

Scale-up studies of bioremediation are usually done using thick packed bed column reactors. Direct use of microbial biomass to develop a free cell packed bed column reactor is not easy due to the low mechanical strength and small particle size of the free cells. Excessive hydrostatic pressures are required to maintain a suitable flow rate in order to withstand the packed bed inside the column. [209] Further, the immobilized cell biomass in a carrier material was found to be more efficient than free cell biomass in the bioremediation. [147] In this context, olive stones discarded from an olive cake industry were collected and milled into a powder form of size less than $1.0 \mathrm{~mm}$. The olive stone powder was used as adsorbent for biosorption of $\mathrm{Cr}(\mathrm{VI})$ from a $10 \mathrm{mg} / \mathrm{L}$ synthetic solution in a batch reactor at $\mathrm{pH} 2.0$ and temperature $25^{\circ} \mathrm{C}$ for $5 \mathrm{~h}$. According to chromium chemistry, $\mathrm{Cr}(\mathrm{VI})$ is stable as $\mathrm{H}_{2} \mathrm{CrO}_{4}$ at low $\mathrm{pH}$ as the $\mathrm{H}^{+}$ion protonate the surface of adsorbent resulting in the adsorbent becoming positively charged. This positive adsorbent has strong affinity to the negatively charged $\mathrm{HCrO}_{4}^{-}$resulting increased $\mathrm{Cr}(\mathrm{VI})$ removal at lower $\mathrm{pH}$. When the $\mathrm{pH}$ increased, the surface of adsorbent is negatively charged due to decrease of proton concentration resulting less affinity for the adsorption of $\mathrm{HCrO}_{4}^{-}$. High-resolution XPS spectra revealed $\mathrm{Cr}(\mathrm{III})$ 
bound to the olive stone powder concluding the removal of $\mathrm{Cr}(\mathrm{VI})$ from acidic solution is a coupled biosorption-reduction reaction. This was further confirmed by the desorption test with deferent reagents $\mathrm{H}_{2} \mathrm{SO}_{4}, \mathrm{NaOH}, \mathrm{HNO}_{3}, \mathrm{HCl}, \mathrm{CH}_{3} \mathrm{COOH}$ and $\mathrm{HOOCCOOH}$. [148]

Lakshmanraj et al. [149] used boiled mucilaginous seeds of Ocimum americanum to investigate chromium removal efficiency from $\mathrm{Cr}(\mathrm{VI})$ solutions. The initial concentration of $\mathrm{Cr}(\mathrm{VI})$ in the solutions were $10 \mathrm{mg} / \mathrm{L}, 20 \mathrm{mg} / \mathrm{L}$ and $40 \mathrm{mg} / \mathrm{L}$ for different run with the biosorbent dosage of 8 $\mathrm{g} / \mathrm{L}$ dry seeds at a $\mathrm{pH}$ 1.5. The authors also proposed the removal mechanism as biosorptionreduction coupled process. The biosorption data fitted well with Langmuir adsorption isotherm. The $\mathrm{Cr}$ (III) uptake was found to be $32 \mathrm{mg} / \mathrm{g}$ of dry seeds. The continuous column reactor packed with boiled mucilaginous seeds as adsorbent bed reduced $80 \%$ of $\mathrm{Cr}(\mathrm{VI})$ at a flow rate of $27 \mathrm{~mL} / \mathrm{hr}$ with the initial concentration of $25 \mathrm{mg} / \mathrm{L} \mathrm{Cr}(\mathrm{VI})$ in the feed solution. However, uptake of $\mathrm{Cr}(\mathrm{III})$ from the aqueous solution was $56.25 \%$. In another study mosambi (Citrus limetta) peel dust was used for removal of $\mathrm{Cr}(\mathrm{VI})$ from aqueous solutions. [150] Batch adsorption study showed similar reduction coupled adsorption as described by Lakshmanraj et al.[149]. The optimum condition were found to be an adsorbent concentration of $20 \mathrm{~g} / \mathrm{L}, \mathrm{pH}$ of 2.0 , equilibrium time of $2 \mathrm{hrs}$, and temperature $40{ }^{\circ} \mathrm{C}$ for $\mathrm{Cr}(\mathrm{VI})$ removal.

\subsection{Biochar}

The thermal decomposition of organic biomass at low temperature and limited oxygen supply generates a byproduct which is rich of activated carbon known as biochar. In recent years, biochar has attracted research interest because of its unique capacity of remediating contaminants from soil and water. $[151,219]$ Biochar usually contains carbon between $30 \%$ and $70 \%$. The carbon is 
a source of protons essential for the reduction of $\mathrm{Cr}(\mathrm{VI})$ and acts as an immobilizer for the $\mathrm{Cr}(\mathrm{III})$. [152] The applications of biochar include: (i) potential carbon sequestration agent in soil, (ii) adsorbent of heavy metals in soil and aqueous solutions, (iii) micro and macro nutrients sink in soil, thereby reducing their leaching losses, and (iv) soil fertility and productivity enhancer. [153156] Biochar stimulates soil microbial communities which enhance the production of protons for $\mathrm{Cr}(\mathrm{VI})$ reduction reactions. The biosorption coupled with a reduction reaction by biochar is enhanced due to the physical and chemical properties such as having a high surface area with oxygenated functional groups. [157-159]

Ramie residues of decorticated stems of ramie plant were air dried room temperature. Then they were smashed to pass through a 149 micron sieve followed by pyrolysis at 300,450 , and $600{ }^{\circ} \mathrm{C}$ in a muffle furnace under nitrogen atmosphere inside. The biochars were washed with deionized water and then dried at $60^{\circ} \mathrm{C}$ for $24 \mathrm{~h}$ followed by sieving to a size $60.15 \mathrm{~mm}$. Biochar of $100 \mathrm{mg}$ was added in a sealed conical flasks containing $50 \mathrm{~mL}$ of $\mathrm{Cr}(\mathrm{VI})$ solution on a thermostat waterwash shaker at $160 \mathrm{rpm}$. The adsorption efficiency decreased with increasing pyrolysis temperature due to a higher aromatic structure and fewer polar functional groups were observed for biochar at high pyrolysis temperature. Low temperature biochar favored chemical adsorption due to presence of carboxyl and hydroxyl groups. The adsorption coupled reduction mechanisms concluded that $\mathrm{Cr}(\mathrm{VI})$ ions were electrostatically attracted by the positively charged biochar surface and then reduced to $\mathrm{Cr}(\mathrm{III})$. [160]

A study involved native Macadamia activated carbon which was cross-linked on the surface with epichlorohydrin, grafting diethylenetriamine and triethylamine to prepare the amino-modified activated carbon for adsorption of $\mathrm{Cr}(\mathrm{VI})$. With the optimum condition of $\mathrm{pH} 5.0$, contact time 2 h, initial $\mathrm{Cr}(\mathrm{VI})$ concentration $100 \mathrm{mg} / \mathrm{L}$ and adsorbent mass $0.10 \mathrm{~g}$, more than $90 \% \mathrm{Cr}(\mathrm{VI})$ was 
adsorbed on the surface of amino-modified activated carbon adsorbent. [161] Bioremediation of $\mathrm{Cr}(\mathrm{VI})$ was conducted with three manures from poultry (PM), cow (CM) and sheep (SM), three respective manure-derived biochars (PM biochar (PM-BC), CM biochar (CM-BC) and SM biochar (SM-BC)) and two surface modified biochars (modified PM-BC (PM-BC-M) and modified SMBC (SM-BC-M)). Chitosan and zerovalent iron (ZVI) were used for surface modification of the biochars during the pyrolysis. The surface modified biochars exhibited enhanced properties for $\mathrm{Cr}(\mathrm{VI})$ reduction. The authors have illustrated an impressive design (figure 4) suggesting the $\mathrm{Cr}(\mathrm{VI})$ reduction by the surface modified biochars. [162]

\section{Biostimulation}

Modification of the environment to stimulate the growth of existing bacteria during bioremediation is called biostimulation. This requires addition of various nutrients and electron acceptors or donors. The microbial reduction of $\mathrm{Cr}(\mathrm{VI})$ can be enhanced by the addition of electron donors like acetate, lactate, or molasses as the mechanism have been discussed earlier. $[163,164]$ The efficiency of different electron donors in biostimulation depends on the indigenous microbial communities and the physicochemical characteristics of each site. This plays an important role in kinetics of the microbial growth and heavy metal reduction in specific environments. Anaerobic biostimulation was used to assay the $\mathrm{Cr}(\mathrm{VI})$ reduction for soil digested chromium solution in three different ways such as (i) soil with acetate to test biological reduction (biostimulated soil); (ii) sterilized soil with acetate to determine abiotic reduction triggered by acetate (control); and (iii) soil with only water as a second control, at alkaline $\mathrm{pH}$ range. [165] In the first case $16 \mathrm{mM} \mathrm{Cr}(\mathrm{VI})$ was reduced to zero in 25 days with only $18 \%$ acetate consumption, however no significant result 
were found in other two cases. Among four species isolated from the soil only Halomonas sp. showed $\mathrm{Cr}(\mathrm{VI})$ resistant by $16 \mathrm{~S}$ rDNA gene amplification and sequencing with MIC of $32 \mathrm{mM}$.

In a sequencing batch reactors, $\mathrm{Cr}(\mathrm{VI})$ reduction study from a ground water was done to evaluate the efficacy of an aerobic and anaerobic system using mesophilic anaerobic digested sludge and aerobic activated sludge from a wastewater treatment plant as inoculums. $\mathrm{Cr}(\mathrm{VI})$ played as an electron acceptor and reduced to $\mathrm{Cr}(\mathrm{III})$ in the anaerobic system resulting more that $98 \%$ of $\mathrm{Cr}(\mathrm{VI})$. In case of aerobic system oxygen was the competitive electron acceptor to $\mathrm{Cr}(\mathrm{VI})$ resulting reduction of $\mathrm{O}_{2}$ to oxide ion resulted lacking of $\mathrm{Cr}(\mathrm{VI})$ reduction. [166] Anaerobic and anoxic conditions were employed to determine the $\mathrm{Cr}(\mathrm{VI})$ reduction ability in two sequencing bioreactors $(\mathrm{SBR})$ fed with groundwater of $3 \mathrm{~L}$ (total volume of reactor=5 L). The design parameters were 0.5 $\mathrm{h}$ feeding time, $22 \mathrm{~h}$ reaction time, $1 \mathrm{~h}$ settling time and $0.5 \mathrm{~h}$ decanting time, and a sludge retention time (SRT) of 10 days. The nominal hydraulic residence time of the SBRs was equal to 1.7 days. The substrate (90\% sugar and $10 \%$ milk on a COD basis) concentration of $200 \mathrm{mg} / \mathrm{L}$, and sufficient $\mathrm{N}$ and $\mathrm{P}$ were added to each SBR. Potassium nitrate as bind oxygen was added to anoxic reactor. Both the reactors were inoculated with a mixture of mesophilic anaerobic digested sludge and aerobic activated sludge from a WTP at a ratio of 1:1 on a mass basis. More than $99 \% \mathrm{Cr}(\mathrm{VI})$ was reduced to $\mathrm{Cr}(\mathrm{III})$ in both the anaerobic and anoxic conditions with initial $\mathrm{Cr}(\mathrm{VI})$ concentrations of 1.8 and $10 \mathrm{mg} / \mathrm{L}$, respectively. Anoxic conditions showed better reduction efficiency with increasing initial $\mathrm{Cr}(\mathrm{VI})$ concentration. The variation of initial $\mathrm{Cr}(\mathrm{VI})$ concentration on the mixed liquor volatile suspended solid production showed no change up to $1.5 \mathrm{mg} / \mathrm{L}$ of $\mathrm{Cr}(\mathrm{VI})$, but, microbial growth was inhibited up to $65 \%$ in both the conditions for initial $\mathrm{Cr}(\mathrm{VI})$ concentrations $20 \mathrm{mg} / \mathrm{L} .[167]$ 
Since bioimmobilization plays a significant role on microbial growth, a series of microcosm experiments were conducted using a range of commercial electron donors on the basis of degrees of lactate polymerization (polylactate) for reduction of $\mathrm{Cr}(\mathrm{VI})$ from waste water. [163] The experiments were conducted using sediments immersed in groundwater with $\mathrm{Cr}(\mathrm{VI})$ amendment. Several types of lactate-based electron donors (hydrogen release compound, HRC; primer-HRC, pHRC; extended release HRC) and the polylactate-cysteine (metal remediation compound, MRC) were used as electron donors. The polylactate compounds stimulated the bacterial biomass and activity better than that of sodium lactate with equivalent carbon concentrations in both the acetates. With the microbial growth concentrations of headspace hydrogen and methane increased. Enrichment of Pseudomonas sp. occurred with all types of lactate additions, and enrichment of sulfate-reducing Desulfosporosinus sp. occurred with almost complete sulfate reduction. The electron donors such as pHRC and MRC showed effective $\mathrm{Cr}(\mathrm{VI})$ removal from the solution.

The effect of the carbon source on microbial community structure in the batch cultures derived from industrial sludge and $\mathrm{Cr}(\mathrm{VI})$ reduction was studied in aerobic batch reactors containing industrial sludge amended with two different carbon sources such as sodium acetate and sucrose separately. From sodium acetate to sucrose led to a 5 to 9.5 -fold increase in biomass and to a 1.3 to 2.1 folds increase in chromium reduction rate. Bacterial species such as Acinetobacter lwoffii, Defluvibacter lusatiensis, Pseudoxanthomonas japonensis, Mesorhizium chacoense, and Flavobacterium suncheonense were developed when sodium acetate was amended. Fungal strains such as Trichoderma viride and Pichia jadinii when sucrose was amended. [168] Isotopic ${ }^{13} \mathrm{CH}_{4}$ as the sole electron donor with an aerobic methane oxidizing (AOM) archaea in batch experiments and long-term performance in the reactor showed that $\mathrm{Cr}(\mathrm{VI})$ reduction was coupled with methane oxidation. High-throughput sequencing of the 16S rRNA genes demonstrated that the microbial 
community had changed substantially after Cr(VI) reduction. The populations of ANME-2d archaea were enhanced during operation. They became the only predominant AOM-related microbe showing the $\mathrm{Cr}(\mathrm{VI})$ reduction was on the basis of anaerobic oxidation of methane. [169] FerroOrozco et al.[170] reported synergistic $\mathrm{Cr}(\mathrm{VI})$ reduction by addition of powdered activated carbon (PAC) to a bioreduction process using aerobic activated sludge (AS). The result showed synergistic $\mathrm{Cr}(\mathrm{VI})$ removal using the AS-PAC system compared to either AS or PAC individually. However, the presence of only PAC did not enhance the growth of biological community.

\section{Microbial Fuel Cell}

Microbial fuel cells (MFC) are an emerging technology combining microbiologically-catalyzed reduction reaction with a biocathode. AMFC was recently shown to reduce $\mathrm{Cr}(\mathrm{VI})$ in an autotrophic environment and simultaneously harvest electricity during the treatment process. [171,172] Biocathode MFCs using electrochemically active microorganisms as catalytic centers at both the anode and cathode show great promise in $\mathrm{Cr}(\mathrm{VI})$ bioremediation. Their operation is inexpensive, the catalysts can self-regenerate and the power supply is sustainable. Biocathodes using microorganisms as catalysts to transfer electrons from the cathode to electron acceptor, similar as the bioanode require an enriched electron-accepting (electrotrophic) biofilm on the surface, formed via acclimatization. In a dual chamber MFC with wastewater inoculums, $\mathrm{Cr}(\mathrm{VI})$ reduction was performed by setting the biocathode potential at $-300 \mathrm{mV}$ and the results were compared with the data for MFC with no applied potential. With the set potential run, the startup time reduced to 19 days with $\mathrm{Cr}(\mathrm{VI})$ reduction rate $19.7 \mathrm{mg} / \mathrm{L} / \mathrm{d}$ and the maximum power density $6.4 \mathrm{~W} / \mathrm{m}^{3}$. In the MFC without set potential, the results were much deteriorated as 26 days startup 
time, reduction rate $14.0 \mathrm{mg} / \mathrm{L} / \mathrm{d}$ and power density $4.1 \mathrm{~W} / \mathrm{m}^{3}$. The result of MFC with $-150 \mathrm{mV}$ set potential was similar to that of $-300 \mathrm{mV}$. But the set potentials of $+200 \mathrm{mV}$ and $-450 \mathrm{mV}$ showed an alteration in the output current density [173]. In another dual chamber MFC the reaction time required for the complete removal $\mathrm{Cr}(\mathrm{VI})$ of $300 \mathrm{mg} / \mathrm{L}, 150 \mathrm{mg} / \mathrm{L}$ and $75 \mathrm{mg} / \mathrm{L}$ were 1,350 min, $750 \mathrm{~min}$ and $180 \mathrm{~min}$, respectively, at a $\mathrm{pH}$ of 2.0. [174] In an MFC system, acetate oxidizing mixed anaerobic culture brought from an anaerobic digester was enriched in anode compartment and a mixture of denitrifying and anaerobic mixed cultures was enriched in the presence of $\mathrm{Cr}(\mathrm{VI})$ as catholyte in cathode compartment. The anode and cathode chamber was separated by a proton exchange membrane. Four consecutive $\mathrm{Cr}(\mathrm{VI})$ spikes were carried out to investigate the effect of initial $\mathrm{Cr}(\mathrm{VI})$ concentration on the reductive activity of the microorganisms and power generation. The catholyte was replenished with fresh medium before the addition of $\mathrm{Cr}(\mathrm{VI})$ at each spike. The $\mathrm{pH}$ of catholyte and anolyte were maintained ranging from 7.2-7.6 and 6.9-7.2, respectively. The $\mathrm{Cr}(\mathrm{VI})$ reduction followed zero order kinetics due to limitations in protons migration through the proton exchange membrane and electrons through the external resistance. The power generation had a direct relationship with initial $\mathrm{Cr}(\mathrm{VI})$ concentration and the specific reduction rate as the reduction rate decreased with the increasing the initial concentration of $\mathrm{Cr}(\mathrm{VI})$ due to inhibitory growth of microbe at high $\mathrm{Cr}(\mathrm{VI})$ concentration or accumulated $\mathrm{Cr}$ (III) or combined effect of both. This was further confirmed by the analysis of the residue and filtrate of the catholyte [175]. A similar type of work has been reported in which synthetic $100 \mathrm{mg} / \mathrm{L} \mathrm{Cr}(\mathrm{VI})$ containing wastewater as catholyte and anaerobic microorganisms as anodic biocatalyst [176]. The maximum power density of $150 \mathrm{~mW} / \mathrm{m}^{2}$ and the maximum open circuit voltage of $0.91 \mathrm{~V}$ were generated with $\mathrm{Cr}(\mathrm{VI})$ as the electron acceptor. 
A dual-chamber MFC was constructed from two plexiglass cubic chambers (liquid volume of each chamber was $70 \mathrm{~mL}$ ) and both chambers were kept air tight. The chambers were separated by a proton exchange membrane. A graphite sheet was used as electrode in a unique way as first for the anode chamber followed by cathode after complete acclimatization in the anode chamber and this process is referred as 'ex-situ MFC'. Different anolyte and catholyte were used with anaerobic activated sludge as inoculums. The in-situ MFC process was a regular dual chamber MFC having two graphite sheets inserted in the anode and cathode simultaneously. The ex-situ MFC which used ex-situ acclimatization on biocathode initially produced a voltage of $290 \mathrm{mV}$ which dropped to $17.9 \mathrm{mV}$ after $24 \mathrm{hrs}$. In comparison, the in-situ MFC which used in-situ acclimatization on biocathode achieved a maximum voltage of $178 \mathrm{mV}$, which decreased by $38.5 \%$ less than that of the ex-situ analog. Anode potentials remained similar and stable between 455 and $449 \mathrm{mV}$ during the operations in both ex-situ and in-situ MFCs, implying the robust activities of anode biofilms. Thus, the variations in voltages were mainly attributed to the performances of cathodes. The maximum power density of the ex-situ MFC was $9.7 \mathrm{~mW} / \mathrm{m}^{2}$ at a current density of $69.7 \mathrm{~mA} / \mathrm{m}^{2}$, 1.2-fold that of the in-situ MFC. The ex-situ MFC showed a higher $\mathrm{Cr}(\mathrm{VI})$ reduction rate of 0.66 $\mathrm{mg} / \mathrm{L} / \mathrm{hr}$ which was 2.9 times higher than that obtained from the in-situ MFC. After $24 \mathrm{hrs}$ of operation the removal of $\mathrm{Cr}(\mathrm{VI})$ was $79.3 \%$ for the ex-situ MFC, which was $20 \%$ higher than that in the in-situ MFC. The Cr(VI) reducing strain Gamma-proteobacteriawas found in the ex-situ biocathode. The number of strains in the ex-situ biocathode was much higher than that in the insitu biocathode. This demonstrated that in the MFCs these bacteria were exoelectrogenic on bioanodes to oxidize organics and electrotrophic on biocathodes to reduce $\mathrm{Cr}(\mathrm{VI})$. [177]

For simultaneous electrochemical reduction of $\mathrm{Cr}(\mathrm{VI})$ in water and generation of bioelectricity, Alumina/nickel nanoparticles dispersed carbon nanofiber (CNF) based electrodes were used in a 
mediator less dual-chamber MFC. The alumina nanoparticles increased the electrical conductivity of the electrode. The Ni nanoparticles served as the catalyst for growing the CNFs on an activated carbon microfiber substrate by chemical vapor deposition and for catalyzing the $\mathrm{Cr}(\mathrm{VI})$ reduction at the cathode. The MFC showed a complete removal of $\mathrm{Cr}(\mathrm{VI})$ at $100 \mathrm{mg} / \mathrm{L}$ concentration with reduction rate of $2.13 \mathrm{~g} / \mathrm{m}^{3} / \mathrm{hr}$ and generated power density of $1540 \mathrm{~mW} / \mathrm{m}^{2}$ with an open circuit potential of $900 \mathrm{mV}$ and cathodic columbic efficiency of $93 \%$. [182] In a similar work, a graphene/biofilm was constructed by amending glucose with grapheme oxide solution first for anode action followed by cathode action in same pot. The maximum power density of the MFC with a graphene biocathode found to be 5.7 times greater than that of the dual-chamber MFC with a graphite felt biocathode. The $\mathrm{Cr}(\mathrm{VI})$ reduction was enhanced in the one-pot MFC resulted 100\% removal of $\mathrm{Cr}(\mathrm{VI})$ of $40 \mathrm{mg} / \mathrm{L}$ concentration in $48 \mathrm{hrs}$ compared to $58.3 \%$ only in the dualchamber MFC. [178]

Plant-microbial fuel cell was used to reduce $\mathrm{Cr}(\mathrm{VI})$ and the performance was investigated by varying initial concentration of $\mathrm{Cr}(\mathrm{VI})$. In a typical design of plant-microbial fuel cell, Ryegrass (Lolium perenne) was chosen because of its rapid growth and large biomass, and its fibrous root system with a dense rhizosphere. Greenhouse grown, healthy and identically sized Ryegrass plants were transplanted into parallel plant-microbial fuel cell reactors under various operation conditions for comparison. The reactors were fed with $1 / 2$ Hoagland's solution and sodium acetate as the electron donor. More than $90 \%$ of $\mathrm{Cr}(\mathrm{VI})$ was reduced in the plant-microbial fuel cell at various initial $\mathrm{Cr}(\mathrm{VI})$ concentration. Interestingly, the reduction efficiency increased with increase of initial $\mathrm{Cr}(\mathrm{VI})$ concentration unlike other MFC as discussed above. There was a linear relationship between the current density with the reduction rate observed as a higher initial $\mathrm{Cr}(\mathrm{VI})$ concentration. The comparison of the results between the biotic plant-microbial fuel cell and 
abiotic control experiment showed the contribution of bioelectrochemical reduction to $\mathrm{Cr}(\mathrm{VI})$ removal was phenomenal. [179] Figure 5 shows the schematic diagram of plant-microbial fuel cell proposed by the authors.

Reduction of $\mathrm{Cr}(\mathrm{VI})$ from contaminated water was investigated using a modified $\mathrm{MFC}$ with $\mathrm{KCl}$ agar salt bridge and anaerobic microorganisms as the anodic biocatalyst. The cathode was an abiotic system. This salt bridged MFC could reduced $100 \%$ and $80 \%$ of $\mathrm{Cr}(\mathrm{VI})$ when initial $\mathrm{Cr}(\mathrm{VI})$ concentration were 5 and $10 \mathrm{mg} / \mathrm{L}$, respectively in 19 days. The MFC system with $5 \mathrm{mg} / \mathrm{L}$ of $\mathrm{Cr}(\mathrm{VI})$ generated a maximum of power density $92.65 \mathrm{~mW} / \mathrm{m}^{2}$ and voltage of $0.35 \mathrm{~V}$. With $10 \mathrm{ml} / \mathrm{L}$ $\mathrm{Cr}(\mathrm{VI})$, the results were $75.08 \mathrm{~mW} / \mathrm{m}^{2}$ and $0.103 \mathrm{~V}$. The advantages of the salt bridge are less complexity and a lower cost in place of expensive membranes like nafion and an abiotic cathode. $[180,181]$

\section{Conclusion}

The review focus on the source of chromium in the environment, its toxicity to the biotic components, chemistry behind the enrichment of $\mathrm{Cr}(\mathrm{VI})$ in the water systems, resistivity mechanism of microorganisms, and recent trend of the bioremediation of $\mathrm{Cr}(\mathrm{VI})$ from water environments. Different anthropogenic activities such as chromite or ferrous-chromite mining, leather tanning, pigment synthesis, electroplating and metal finishing are causes of the enrichment of $\mathrm{Cr}(\mathrm{VI})$ in the water systems. $\mathrm{Cr}(\mathrm{VI})$ causes toxicity in the living organisms in terms of cellular reduction of $\mathrm{Cr}(\mathrm{VI})$ to $\mathrm{Cr}(\mathrm{III})$. The reactive species generation inside cells, $\mathrm{Cr}$ (III)-protein coordination complex formation, DNA damage, can contribute to carcinogenicity. Further absorption on the stomach wall, effects on sperm productivity, carcinomas of the bronchial 
systems, and neurotoxicity can be seen in humans. $\mathrm{Cr}(\mathrm{VI})$ removal from water is possible by reducing the chemical species to less soluble $\mathrm{Cr}$ (III) followed by hydration to solidify the reduced species rather than direct precipitation of $\mathrm{Cr}(\mathrm{VI})$. Adsorption of $\mathrm{Cr}(\mathrm{VI})$ is possible by attachment on the functional mass of some live or dead cells. Bacteria, fungi, plant species and nuts, algae have shown capability to bioreduce or biosorp or reduce via coupled adsorption due to their versatile life cycles. A wide range of bacteria- direct chromium reducing bacteria, sulphur and iron reducing bacteria and engineered bacterial profile - have shown effective bioreduction in a variety of conditions including $\mathrm{pH}$, temperature, contact time, agitation, nutrient medium, redox stimulating reagents, carbon and nitrogen sources, immobilizers, free cell reductase and many more. Fungal consortium, plant species and algae have also proved the $\mathrm{Cr}(\mathrm{VI})$ can be reduced by a reduction coupled adsorption mechanism. They too can operate under varying different conditions of adsorbents and adsorbates speciation, $\mathrm{pH}$, temperature, nutrient availability, functional induction of adsorbents and surface modifications. Laboratory scale microbial fuel cells are employed to reduce $\mathrm{Cr}(\mathrm{VI})$ from water gains a new light of the reduction-cum-electricity generation technique. Inadequate reports regarding the scale-up test of the $\mathrm{Cr}(\mathrm{VI})$ bioremoval suggests that more focus should be given in the pilot and industrial scale.

\section{References}

[1] K.R. Reddy, C. Cameselle, Electrochemical remediation technologies for polluted soils, sediments and groundwater, John Wiley and Sons, 2009.

[2] A. Tiwary, J. Colls, Air Pollution: Measurement, Modelling and Mitigation, second ed., CRC Press, 2009.

[3] Bureau of Indian Standards, Indian Standard Drinking Water Specification, second revision, 2012. 
[4] United States Environmental Protection Agency, National Primary Drinking Water Regulations, 2009.

[5] United States Geological Survey, Ground Water and Surface Water: A Single Resource, circular 1139 by C. Denver, 1998.

[6] D.E. Kimbrough, Y. Cohen, A.M. Winer, L. Creelman, C. Mabuni, Crit. Rev. Env. Sci. Technol. 29 (1999) 1-46.

[7] M. Gheju, Water Air Soil Pollut. 222 (2011) 103-148.

[8] C.E. Barrera-Díaz, V. Lugo-Lugo, B. Bilyeu, J. Haz. Mat. 223-224 (2012) 1-12.

[9] A. Bielicka, I. Bojanowska, A. Wiśniewski, Pol. J. Environ. Stud. 14 (2005) 5-10.

[10] B. Dhal, H.N. Thatoi, N.N. Das, B.D. Pandey, J. Haz. Mat. 250-251 (2013) 272-291.

[11] J. Westbrook, in: M. Grayson (eds.), Kirk-Othmer Encyclopedia of Chemical Technology (Vol. 6), 3rd ed., Wiley-Interscience, New York, 1983, pp. 54-82.

[12] United States Geological Survey, Mineral Commodity Summaries, by Suzette M. Kimball, 2016, pp. 48-49.

[13] P. Malaviya, A. Singh, Crit. Rev. Microbiol. 42 (2016) 607-633.

[14] W.M. Haynes, CRC Handbook of Chemistry and Physics, 95th ed., CRC Press, Taylor and Francis, 2014-2015.

[15] G.R. Wallwork, Rep. Prog. Phys. 39 (1976) 401-485.

[16] S. Langard, Am. J. Ind. Med. 17 (1990) 189-215.

[17] D. Rai, L.E. Eary, J.M. Zachara, Sci. Total Environ. 86 (1989) 15-23.

[18] H.A. Headlam, P.A. Lay, J. Inor. Biochem. 162 (2016) 227-237.

[19] A. Zhitkovich, Chem. Res. Toxicol. 24 (2011) 1617-1629.

[20] A., Lamb, G. Evans, J.R. King, Bull. Math. Biol. 75 (2013) 1472-1500.

[21] J. Messer, M. Reynolds, L. Stoddard, A. Zhitkovich, Free Radical Biol. Med. 40 (2006) 19811992.

[22] United States Environmental Protection Agency, Toxicological Review of Trivalent Chromium, CAS No. 16065-83-1, 1998.

[23] H.J. Gibb, P.S. Lees, P.F. Pinsky, B.C. Rooneym, Am. J. Ind. Med. 38 (2000) 115-126.

[24] J. Zhang, X. Li, Chin. J. Prev. Med. 21 (1987) 262-264.

[25] P. Singh, D.K. Chowdhuri, Mol. Neurobiol. (2016), doi:10.1007/s12035-016-9909-z 
[26] S.H. Kim, I.C. Lee, H.S. Baek, C. Moon, S.S. Kang, C.S. Bae, S.H. Kim, D.H. Shin, J. Kim, Mol. Cel. Toxicol. 8 (2012) 249-256.

[27] J.N. Meegoda, W. Kamolpornwijit, J.H. Batagoda, Indian Geotech J. (2016), doi: $10.1007 / \mathrm{s} 40098-016-0208-4$

[28] Z. An, H. Zhang, Q. Wen, Z. Chen, M. Du, Desalination 354 (2014)181-188.

[29] A.M. Graham, E.J. Bouwer, Env. Sci. Technol. 44 (2010) 136-142.

[30] Y. Yuan, S. Yang, D. Zhou, F. Wu, J. Haz. Mat. 307 (2016) 294-301.

[31] X. Chang, M. Li, Q. Liu, Q. Liu, J. Yao, RSC Adv. 6 (2016) 46879-46888.

[32] G. Choppala, A. Kunhikrishnan, B. Seshadri, J.H. Park, R. Bush, N. Bolan, J. Geochem. Explor. (2016), http://dx.doi.org/10.1016/j.gexplo.2016.07.012

[33] X. He, B. Hou, C. Li, Q. Zhu, Y. Jiang, L. Wu, Electrochim. Acta 130 (2014) 245-252.

[34] W. Weng, M. Wang, X. Gong, Z. Wang, D. Wang, Z. Guo, Electrochim. Acta 212 (2016) 162-170.

[35] M.A. Daous, A.H. El-Shazly, Int. J. Electrochem. Sci. 7 (2012) 3513-3526.

[36] H. Hossini, A. Rezaee, H. Masoumbeigi, J. Heal. Pol. Sustain. Heal. 1 (2014) 1-7.

[37] L. Ai, J. He, Y. Wang, C. Wei, J. Zhan, RSC Adv. 6 (2016) 56108-56115.

[38] M. Celebi, M. Yurderi, A. Bulut, M. Kaya, M. Zahmakiran, Appl. Catal., B 180 (2016) 5364.

[39] D.D. La, R. Ramanathan, A. Rananaware, V. Bansal, S.V. Bhosale, RSC Adv. 6 (2016) 33931-33936.

[40] Z. Fan, Y. Zhao, W. Zhai, L. Qiu, H. Li, M.R. Hoffmann, RSC Adv. 6 (2016) 2028-2031.

[41] M. Yadav, Q. Xu, Chem. Commun. 49 (2013) 3327-3329.

[42] P.K.S.M. Rahman, S. Bastola, Front. Environ. Sci. 2 (2014), doi: 10.3389/fenvs.2014.00022

[43] D. Pradhan, D.J. Kim, J.G. Ahn, G.R. Chaudhury, S.W. Lee, J. Ind. Eng. Chem. 16 (2010) 866-871.

[44] D.R. Lovley, Annu. Rev. Microbiol. 47 (1993) 263-290.

[45] D.R. Lovley, Adv. Agron. 54 (1995) 175-231.

[46] L.B. Sukla, N. Pradhan, S. Panda, B.K. Mishra, Environmental Microbial Biotechnology, Springer, 2015.

[47] M.L. Gargas, R.L. Norton, M.A. Harris, D.J. Paustebach, B.L. Finley, Risk Anal. 14 (1994) 1019-1024. 
[48] N.T. Joutey, H. Sayel, W. Bahafid, N.E. Ghachtouli, Rev. Environ. Contam. Toxicol. 233 (2015) 45-69.

[49] A.M. Standeven, K.E. Wetterhahn, Carcinogenesis 12 (1991) 1733-1737.

[50] Y. Suzuki, K. Fukuda, Arch. Toxicol. 64 (1990) 169-176.

[51] K.M. Borges, J.S. Boswell, R.H. Liebross, K.E. Wetterhahn, Carcinogenesis 12 (1991) 551561.

[52] D. Guttmann, G. Poage, T. Johnston, A. Zhitkovich, Chem. Res. Toxicol. 21 (2008) 21882194.

[53] M. Miransari, Biotechnol. Adv. 29 (2011) 645-653.

[54] E.M.N. Chirwa, P.E. Molokwane, In: A. Sofo (ed), Biodiversity, Cambridge: In Tech, 2011.

[55] M. Qamar, M.A. Gondal, Z.H. Yamani, J. Mol. Catal. A. Chem. 341 (2011) 83-88.

[56] C. Viti, L. Giovannetti, In: S.N. Singh, R.D. Tripathi (eds.), Environmental Bioremediation Technologies, Springer, Berlin, 2007, p. 57.

[57] V. Somasundaram, L. Philip, S.M. Bhallamudi, Chem. Eng. J. 171 (2011) 572-581.

[58] H. Ksheminska, D. Fedorovych, L. Babyak, D. Yanovych, P. Kaszycki, H. Koloczek, Proc. Biochem. 40 (2005) 1565-1572.

[59] H. Alvarez, R. Moreno-Sanchez, C. Cervantes, J. Bacteriol. 181 (1999) 7398-7400.

[60] R. Branco, A.P. Chung, T. Johnston, V. Gurel, P. Morais, A. Zhitkovich, J. Bacteriol. 190 (2008) 6996-7003.

[61] G. Cabrera, M. Viera, J.M. Gomez, D. Cantero, E. Donati, Biodegradation 18 (2007) 505513.

[62] S. Srivastava, I.S. Thakur, Biodegradation 18 (2007) 637-646.

[63] B. Saha, C. Orvig, Coord. Chem. Rev. 254 (2010) 2959-2972.

[64] T. Barkay, J. Schaefer, Curr. Opion. Microbiol. 4 (2001) 318-323.

[65] V.I. Romanenko, V.N. Koren'kov, Mikrobiologiya 43 (1977) 414-417.

[66] V. Somasundaram, L. Philip, S.M. Bhallamudi, J. Haz. Mat. 172 (2009) 606-617.

[67] S. Dey, A.K. Paul, J. Haz. Mat. 213-214 (2012) 200-206.

[68] J. Chandhuru, S. Harshitha, K. Sujitha, D.J. MukeshKumar, J. Acad. Indus. Res. 1 (2012) 317-319.

[69] S. Farag, S. Zaki, J. Environ. Biol. 31 (2010) 877-882.

[70] M.K. Guria, A.K. Guha, M. Bhattacharyya, J. Env. Chem. Eng. 2 (2014) 424-433. 
[71] D. Cetin, S. Donmez, G. Donmez, J. Environ. Manage. 88 (2008) 76-82.

[72] T. Seema, V. Krishnamurthy, M. Riaz, Int. J. Eng. Res. Appl. 2 (2012) 961-966.

[73] H. Sayel, W. Bahafid, N.T. Joutey, K. Derraz, K.F. Benbrahim, S.I. Koraichi, N. El Ghachtouli, Ann. Microbiol. 62 (2012) 1269-1277.

[74] S. Sharma, A. Adholeya, J. Environ. Sci. Technol. 5 (2012) 142-154.

[75] S. Sharma, P. Malaviya, Ecol. Eng. 91 (2016) 419-425.

[76] S. Ge, W. Ai, X. Dong, Genome Announc. 4 (2016), doi:10.1128/genomeA.01760-15

[77] F.S. Carlos, P. Giovanella, J. Bavaresco, C.D.S. Borges, F.A.D.O. Camargo, Water Air Soil Pollut. 227:175 (2016), DOI: 10.1007/s11270-016-2872-5

[78] Y.G. Liu, W.H. Xu, G.M. Zeng, J. Environ. Sci. 16 (2004) 795-801.

[79] M. Narayani, K.V. Shetty, Crit. Rev. Environ. Sci. Technol. 43 (2013) 955-1009.

[80] B. Volesky, In: B. Volesky (ed), Biosorption of Heavy Metals, CRC Press, Boca Raton, 1990, pp. 3-6.

[81] G. Dogan, N.M. Dogan, G.A. Doganli, Asian J. Chem. 26 (2014) 7359-7363.

[82] S. Ejaz, F.Z. Rizvi, S. Anwar, M. Faisal, Int. J. Environ. Sci. Technol. 10 (2013) 709-718.

[83] P.A. Wani, O.H. Ayoola, J. Env. Sci. Technol. 8 (2015) 122-130.

[84] V. Mishra, D.P. Samantaray, S.K. Dash, A.K. Sethi, B.B. Mishra, Biosci. Bitechnol. Res. Asia 7 (2010) 963-967.

[85] D. Long, X. Tang, K. Cai, G. Chen, L. Chen, D. Duan, J. Zhu, Y. Chen, J. Haz. Mat. 256-257 (2013) 24-32.

[86] S. Focardi, M. Pepi, G. Landi, S. Gasperini, M. Ruta, P.D. Biasio, S.E. Focardi, Int. Biodet. Biodegrad. 66 (2012) 63-70.

[87] M.E.M. Mabrouk, M.A. Arayes, S.A. Sabry, Biotechnol. Biotechnol. Equip. 28 (2014) 659667.

[88] S. Sagar, A. Dwivedi, S. Yadav, M. Tripathi, S.D. Kaistha, Chemosphere 86 (2012) 847-852.

[89] C. Viti, A. Pace, L. Giovannetti, Curr. Microbiol. 46 (2003) 1-5.

[90] S. Dey, A.K. Paul, AIMS Bioeng. 3 (2016) 337-351.

[91] Z. Fang, J. Zhang, B. Liu, G. Du, J. Chen, Bioresour. Technol. 140 (2013) 286-291.

[92] J.H. Jeong, O.M. Lee, Y.D. Jeon, J.D. Kim, N.R. Lee, C.Y. Lee, H.J. Son, Process Biochem. 45 (2010) 1738-1745.

[93] K. Bhange, V. Chaturvedi, R. Bhatt, 3 Biotech 6 (2016), doi:10.1007/s13205-016-0370-5 
[94] M. Narayani, V.K. Shetty, J. Microbiol. Biotechnol. 22 (2012) 690-698.

[95] Z.A. Zakaria, Z. Zakaria, S. Surif, W.A. Ahmad, J. Haz. Mat. 146 (2007) 30-38.

[96] A. Hora, V.K. Shetty, World J. Microbiol. Biotechnol. 30 (2014) 3211-3219.

[97] J.L. You, L.X. Cao, G.F. Liu, S.N. Zhou, H.M. Tan, Y.C. Lin, World J. Microbiol. Biotechnol. 21 (2005) 679-682.

[98] P. Jain, A. Amatullah, S.A. Rajib, H.M. Reza, Am. J. Biochem. Biotechnol. 8 (2012) 111117.

[99] Y. Rehman, F.Z. Rizvi, M. Faisal, S. Hasnain, Microbiology 82 (2013) 428-433.

[100] Z. Ran, W. Bi, C.Q. Tao, L.X. Xia, L. Min, H. Dong, G.D. Bei, W. Juan, F. Chun, Biomed. Environ. Sci. 29 (2016) 127-136.

[101] E.K. Field, R. Gerlach, S. Viamajala, L.K. Jennings, B.M. Peyton, W.A. Apel, Biodegradation 24 (2013) 437-450.

[102] J. Tang, Y. Hu, S.A. Baig, T. Sheng, X. Xu, Desalination Water Treat. 52 (2014) 22-24.

[103] F. Camargo, B. Okeke, F. Bento, W. Frankenberger, Bioremediat. J. 8 (2004) 23-30.

[104] G.B. Sau, S. Chatterjee, S. Sinha, S.K. Mukherjee, Pol. J. Microbiol. 57 (2008) 327-332.

[105] M.S.M. Mangaiyarkarasi, S. Vincent, S. Janarthanan, T.S. Rao, B.V.R. Tata, Saudi J. Biol. Sci. 18 (2011) 157-167.

[106] F.Z. Tanu, A. Hakim, S. Hoque, Am. J. Environ. Protect. 5 (2016) 35-38.

[107] V. Kumari, A. Yadav, I. Haq, S. Kumar, R.N. Bharagava, S.K. Singh, A. Raj, J. Environ. Manage. 183 (2016) 204-211.

[108] S. Dey, A.K. Paul, Chemosphere 156 (2016) 69-75.

[109] Y.T. Wang, C.S. Xiao, War. Res. 29 (1995) 2467-2474.

[110] R.M. Hlihor, H. Figueiredo, T. Tavares, M. Gavrilescu, Process Saf. Environ. Prot. 108 (2017) 44-56.

[111] J.F. Heidelberg, R. Seshadri, S.A. Haveman, C.L. Hemme, I.T. Paulsen, et al. Nat. Biotechnol. 22 (2004) 554-559.

[112] D.R. Lovley, E.J. Phillips, Appl. Environ. Microbiol. 60 (1994) 726-728.

[113] B. Chardin, A. Dolla, F. Chaspoul, M.L. Fardeau, P. Gallice, M. Bruschi, Appl. Microbiol. Biotechnol. 60 (2002) 352-360.

[114] E.C. Butler, L. Chen, C.M. Hansel, L.R. Krumholz, A.S.E. Madden, Y. Lan, Env. Sci. Process. Impacts 17 (2015) 1930-1940. 
[115] A. Klonowska, M.E. Clark, S.B. Thieman, B.J. Giles, J.D. Wall, M.W. Fields, Appl. Microbiol. Biotechnol. 78 (2008) 1007-1016.

[116] H. Brim, A. Venkateswaran, H.M. Kostandarithes, J.K. Fredrickson, M.J. Daly, Appl. Environ. Microbiol. 69 (2003) 4575-4582.

[117] G.B. Slobodkina, E.A. Bonch-Osmolovskaya, A.I. Slobodkin, Microbiology 76 (2007) 530534.

[118] R. Singh, H. Dong, D. Liu, L. Zhao, A.R. Marts, E. Farquhar, D.L. Tierney, C.B. Almquist, B.R. Briggs, Geochim. Cosmochim. Acta 148 (2015) 442-456.

[119] D.R. Ryan, W.D. Leukes, S.G. Burton, Biotechnol. Prog. 21 (2005) 1068-1074.

[120] M. Jena, D. Pradhan, T. Das, Int. J. Env. Waste Manage. 9 (2012) 221-231.

[121] D. Park, Y.S. Yun, J.M. Park, Process Biochem. 40 (2005) 2559-2565.

[122] J.F. Cárdenas-González, I. Acosta-Rodríguez, Bioinorganic Chemistry and Applications 676243, 2010. doi:10.1155/2010/676243

[123] J.G.S. Mala, B.U. Nair, R. Puvanakrishnan, J. Gen. Appl. Microbiol. 52 (2006) 179-186.

[124] K. Turnau, E. Orlwska, P. Ryszka, S. Zubek, T. Anielska, S. Gawronski, A. Jurkiewicz, Soil Water Pollut. Monit. Prot. Remed. 3 (2006) 533-551.

[125] J. Bai, X. Wu, F. Fan, W. Tian, X. Yin, L. Zhao, F. Fan, Z. Li, L. Tian, Z. Qin, J. Guo, Enzyme Microb. Tech. 51 (2012) 382-387.

[126] G. Chen, J. Fan, R. Liu, G. Zeng, A. Chen, Z. Zou, Environ. Tech. 33 (2012) 2653-2659.

[127] P. Anand, J. Isar, S. Saran, R.K. Saxena, Bioresour. Technol. 97 (2006) 1018-1025.

[128] D. Sivakumar, Global J. Environ. Sci. Manage. 2 (2016) 105-124.

[129] R. Singh, M. Kumar, N.R. Bishnoi, Ecol. Eng. 91 (2016) 31-40.

[130] A. Mishra, A. Malik, Bioresour. Technol. 171 (2014) 217-226.

[131] S. Cunningham, D. Ow, Plant Physiol. 110 (1996) 715-719.

[132] D. Salt, I. Pickering, R. Prince, D. Gleba, S. Dushenkov, R. Smith, I. Raskin, Environ. Technol. 31 (1997) 1636-1644.

[133] B. Duarte, M. Delgado, I. Cac-ador, Chemosphere 69 (2007) 836-840.

[134] S. Redondo-Go'mez, E. Mateos-Naranjo, I. Vecino-Bueno, S. Feldman, J. Haz. Mat. 185 (2011) 862-869.

[135] E. Ranieri, P. Gikas, Water Air Soil Pollut. 2014. DOI 10.1007/s11270-014-1981-2 
[136] E. Ranieri, U. Fratino, A. Petrella, V. Torretta, E.C. Rada, Environ. Sci. Pollut. Res. 23 (2016) 15983-15989.

[137] B. Duarte, V. Silva, I. Cacador, Ecotoxicol. Environ. Saf. 83 (2012) 1-7.

[138] S.C. McCutcheon, J.L. Schnoor, Phytoremediation: Transformation and Control of Contaminants, John Wiley \& Sons, 2004.

[139] A. Mishra, B.D. Tripathi, A.K. Rai, Ecotoxicol. Environ. Saf. 132 (2016) 420-428.

[140] S. Kuppusamy, P. Thavamani, M. Megharaj, K. Venkateswarlu, Y.B. Lee, R. Naidu, Proc. Saf. Env. Protec. 100 (2016) 173-182.

[141] L. Deng, H.L. Wang, N.S. Deng, J. Haz. Mat. 138 (2006) 288-292.

[142] V. Gupta, A. Rastogi, J. Haz. Mat. 163 (2009) 396-402.

[143] C. Das, K. Naseera, A. Ram, R.M. Meena, N. Ramaiah, J. Appl. Phycol. 29 (2017) 235-243.

[144] Z. Chen, S. Song, Y. Wen, Sci. Total Environ. 572 (2016) 361-368.

[145] F.B. de Souza, H.D.L. Brandão, F.V. Hackbarth, A.A.U. de Souza, R.A.R. Boaventura, S.M.A.G.U. de Souza, V.J.P. Vilar, Chem. Eng. J. 283 (2016) 903-910.

[146] F.V. Hackbarth, D. Maass, A.A.U. de Souza, V.J.P. Vilar, S.M.A.G.U. de Souza, Chem. Eng. J. 290 (2016) 477-489.

[147] J.C. Mamaril, E.T. Paner, B.M. Alpante, Biodegradation 8 (1997) 275-285.

[148] M.A.M. Lara, M.C. de-Hoces, A.R. Gálvez, A.P. Muñoz, M.C.T. Miranda, Water Sci. Technol. 73 (2016) 2680-2688.

[149] L. Lakshmanraj, A. Gurusamy, M.B. Gobinath, R. Chandramohan, J. Haz. Mat. 169 (2009) 1141-1145.

[150] R. Saha, K. Mukherjee, I. Saha, A. Ghosh, S.K. Ghosh, B. Saha, Res. Chem. Intermed. 39 (2013) 2245-2257.

[151] M. Ahmad, A.U. Rajapaksha, J.E. Lim, M. Zhang, N. Bolan, D. Mohan, M. Vithanage, S.S. Lee, Y.S. Ok, Chemosphere 99 (2014) 19-33.

[152] A.U. Rajapaksha, M. Vithanage, Y.S. Ok, C. Oze, Environ. Sci. Technol. 47 (2013) 97229729.

[153] T.J. Clough, L.M. Condron, C. Kammann, C. Muller, Agronomy 3 (2013) 275-293.

[154] O.A. Knowles, B.H. Robinson, A. Contangelo, L. Clucas, Sci. Total. Environ. 409 (2011) 3206-3210. 
[155] S. Mandal, R. Thangarajan, N. Bolan, B. Sarkar, N. Khan, Y.S. Ok, R. Naidu, Chemosphere 142 (2015) 120-127.

[156] J. Novak, K. Ro, Y.S. Ok, G. Sigua, K. Spokas, S. Uchimiya, N. Bolan, Chemosphere 142 (2016) 1-3.

[157] G.K. Choppala, N.S. Bolan, M. Megharaj, Z. Chen, R. Naidu, J. Environ. Qual. 41 (2012) 1175-1184.

[158] M.I. Inyang, B. Gao, Y. Yao, Y. Xue, A. Zimmerman, A. Mosa, P. Pullammanappallil, Y.S. Ok, X. Cao, Crit. Rev. Environ. Sci. Technol. 46 (2016) 406-433.

[159] D. Mohan, A. Sarswat, Y.S. Ok, C.U. Pittman, Bioresour. Technol. 160 (2014) 191-202.

[160] L. Zhou, Y. Liu, S. Liu, Y. Yin, G. Zeng, X. Tan, X. Hu, X. Hu, L. Jiang, Y. Ding, S. Liu, X. Huang, Bioresour. Technol. 218 (2016) 351-359.

[161] V.E. Pakade, L.C. Maremeni, T.D. Ntuli, N.T. Tavengwa, S. Afr. J. Chem. 69 (2016) 180188.

[162] S. Mandal, B. Sarkar, N. Bolan, Y.S. Ok, R. Naidu, J. Env. Manage. 186 (2017) 277-284.

[163] E.L. Brodie, D.C. Joyner, B. Faybishenko, M.E. Conrad, C. Rios-Velazquez, J. Malave, R. Martinez, B. Mork, A. Willett, S. Koenigsberg, D.J. Herman, M.K. Firestone, T.C. Hazen, Chemosphere 85 (2011) 660-665.

[164] C. Varadharajan, R. Han, H.R. Beller, L. Yang, M.A. Marcus, M. Michel, P.S. Nico, J. Environ. Qual. 44 (2015) 729-738.

[165] P. Lara, E. Morett, K. Juárez, Environ. Sci. Pollut. Res. 2016, doi:10.1007/s11356-016$7191-2$

[166] D. Mamais, C. Noutsopoulos, I. Kavallari, E. Nyktari, Chemosphere 152 (2016) 238-244.

[167] E. Panousi, D. Mamais, C. Noutsopoulos, K. Antoniou, K. Koutoula, S. Mastrantoni, C. Koutsogiannis, A. Gkioni, J. Chem. Technol. Biotechnol. 91 (2016) 1681-1687.

[168] A.G. Tekerlekopoulou, G. Tsiamis, E. Dermou, S. Siozios, K. Bourtzis, D.V. Vayenas, Biotechnol. Bioeng. 107 (2010) 478-487.

[169] Y.Z. Lu, L. Fu, J. Ding, Z.W. Ding, N. Li, R.J. Zeng, Water Res. 102 (2016) 445-452.

[170] A.M. Ferro ‘O’rozco, E.M. Contreras, N.E. Zaritzky, Bioresour. Technol. 102 (2011) 24952502.

[171] L. Huang, J. Chen, X. Quan, F. Yang, Bioprocess Biosyst. Eng. 33 (2010) 937-945.

[172] N. Xafenias, Y. Zhang, C.J. Banks, Int. J. Environ. Sci. Technol. 12 (2015) 2435-2446. 
[173] L. Huang, X. Chai, G. Chen, B.E. Logan, Environ. Sci. Technol. 45 (2011) 5025-5031.

[174] P. Gangadharan, I.M. Nambi, Water Sci. Technol. 71 (2015) 353-358.

[175] M. Tandukar, S.J. Huber, Takashionodera, S.G. Pavlostathis, Environ. Sci. Technol. 43 (2009) 8159-8165.

[176] G. Wang, L. Huang, Y. Zhang, Biotechnol. Lett. 30 (2008) 1959-1966.

[177] X. Wu, X. Zhu, T. Song, L. Zhang, H. Jia, P. Wei, Bioresour. Technol. 180 (2015) 185-191.

[178] T. Song, Y. Jin, J. Bao, D. Kang, J. Xie, J. Haz. Mat. 317 (2016) 73-80.

[179] N. Habibul, Y. Hu, Y.K. Wang, W. Chen, H.Q. Yu, G.P. Sheng, Environ. Sci. Technol. 50 (2016) 3882-3889.

[180] A.C. Sophia, S. Saikant, J. Env. Chem.Eng. 4 (2016) 2402-2409.

[181] A.C. Sophia, S. Saikant, J. Water Proc. Eng. 11 (2016) 39-45.

[182] S. Gupta, A. Yadav, N. Verma, Chem. Eng. J. 307 (2017) 729-738.

[183] Geological Survey of Japan, Atlas of Eh-pH diagrams, Inter comparison of thermodynamic databases. Open File Report No.419, prepared by National Institute of Advanced Industrial Science and Technology, 2005, p. 78.

[184] F. Chang, C. Tian, S. Liu, J. Ni, Chem. Eng. J. 298 (2016) 75-81.

[185] G. Shimei, M. Zhou, X. Dong, Y. Lu, G. Shichao, Appl. Microbiol. Biotechnol. 97 (2012) 2131-2137.

[186] D.P. Samantaray, B.B. Mishra, The Bioscan 7 (2012) 627-629.

[187] M.A. Amoozegar, A. Ghasemi, M.R. Razavi, S. Naddaf, Process Biochem. 42 (2007) 14751479.

[188] M.R. VanEngelen, B.M. Peyton, M.R. Mormile, H.C. Pinkart, Biodegradation 19 (2008) 841850.

[189] J.K. Zhang, Z.H. Wang, Y. Ye, Appl. Biochem. Biotechnol. 180 (2016) 1328-1344.

[190] A. Essahale, M. Malki, I. Marin, M. Moumni, Indian J. Microbiol. 52 (2012) 48-53.

[191] A.R. Shakoori, M. Makhdoom, R.U. Haq, Appl. Microbiol. Biotechnol. 53 (2000) 348-351.

[192] S. Dey, A.K. Paul, Braz. J. Microbiol. 44 (2013) 307-315.

[193] B. Rida, K. Yrjälä, S. Hasnain, J. Microbiol. Biotechnol. 22 (2012) 547-554.

[194] A. Pal, S. Datta, A.K. Paul, Braz. Arch. Biol. Technol. 56(2013) 505-512.

[195] S. Subramanian, S. Sam, G. Jayaraman, Afr. J. Microbiol. Res. 6 (2012) 7339-7349.

[196] K. Rabaey, W. Ossieur, M. Verhaege, W. Verstraete, Water Sci. Technol. 52 (2005) 515-523. 
[197] U. Thacker, R. Parikh, Y. Shouche, D. Madamwar, Proc. Biochem. 41 (2006) 1332-1337.

[198] E. Sahinkaya, A. Kilic, M. Altun, K. Komnitsas, P.N.L. Lens, J. Haz. Mat. 219-220 (2012) 253-259.

[199] Y. Shi, L. Chai, Z. Yang, Q. Jing, R. Chen, Y. Chen, Bioprocess. Biosyst. Eng. 35 (2012) 843-850.

[200] S. Banerjee, S.R. Joshi, T. Mandal, G. Halder, Chemosphere 167 (2017) 269-281.

[201] P. Chovanec, C. Sparacino-Watkins, N. Zhang, P. Basu, J.F. Stolz, Front. Microbiol. 2012, doi: 10.3389/fmicb.2012.00416

[202] V.Y. Shukla, D.R. Tipre, S.R. Dave, Bioremediat. J. 18 (2014) 128-135.

[203] M.G. Ziagova, A.I. Koukkou, M. Liakopoulou-Kyriakides, Chemosphere 95 (2014) 535-540.

[204] L. Xu, M. Luo, W. Li, X. Wei, K. Xie, L. Liu, C. Jiang, H. Liu, J. Haz. Mat. 185 (2011) 11691176.

[205] S. Das, S. Pandey, S.K. Pradhan, M. Sudarshan, A. Chakraborty, H.N. Thatoi, Soil Sediment Contam. 24 (2015) 206-221.

[206] N.M. Doğan, E. Evgen, G.A. Doğanlı, G. Doğan, J. Biol. Chem. 43 (2015) 295-300.

[207] Z. Chen, L. Zou, H. Zhang, Y. Chen, P. Liu, X. Li, Int. Biodet. Biodeg. 94 (2014) 146-151.

[208] M.P. Watts, T.V. Khijniak, C. Boothman, J.R. Lloyd, Appl. Environ. Microbiol. 81 (2015) 5511-5518.

[209] R. Gupta, P. Ahuja, S. Khan, R.K. Saxena, H. Mohapatra, Curr. Sci. 78 (2000) 1967-1973.

[210] F.A.O. Camargo, B.C. Okeke, F.M. Bento, W.T. Frankenberger, Appl. Microb. Biotechnol. 62 (2003) 569-573.

[211] S. Mishra, N. Verma, J. Ind. Eng. Chem. 36 (2016) 346-354.

[212] R. Gottipati, S. Mishra, J. Ind. Eng. Chem. 36 (2016) 355-363.

[213] J. Yang, M.Y.W. Chen, J. Ind. Eng. Chem. 25 (2015) 414-422.

[214] A. Maleki, B. Hayati, M. Naghizadeh, S.W. Joo, J. Ind. Eng. Chem. 28 (2015) 211-216.

[215] D. W. Lee, B. R. Yoo, J. Ind. Eng. Chem. 38 (2016) 1-12.

[216] A. Gopalakrishnan, R. Krishnan, S. Thangavel, G. Venugopal, S.J. Kim, J. Ind. Eng. Chem. 30 (2015) 14-19.

[217] S.A. Jabasingh, D. Lalith, P. Garre, J. Ind. Eng. Chem. 23 (2015) 79-92.

[218] M.N. Joubani, M.S. Siboni, J.K. Yang, M. Gholami, M. Farzadkia, J. Ind. Eng. Chem. 22 (2015) 317-323. 
[219] T.M.A. Fattah, M.E. Mahmoud, S.B. Ahmed, M.D. Huff, J.W. Lee, S. Kumar, J. Ind. Eng.

Chem. 22 (2015) 103-109.

Table 1. Standard parameters of toxic metal in drinking water. $[3,4]$

\begin{tabular}{|c|c|c|c|c|c|}
\hline \multirow[b]{2}{*}{ Contaminant } & \multicolumn{2}{|c|}{ USEPA standard } & \multirow{2}{*}{$\begin{array}{l}\text { Indian } \\
\text { Standard } \\
\text { Maximum } \\
\text { Contaminant } \\
\text { Level (MCL) } \\
\text { in mg/L }\end{array}$} & \multirow[b]{2}{*}{$\begin{array}{l}\text { Potential Health Effects } \\
\text { from Long-Term Exposure } \\
\text { Above the MCL }\end{array}$} & \multirow[b]{2}{*}{$\begin{array}{l}\text { Sources of Contaminant in } \\
\text { Drinking Water }\end{array}$} \\
\hline & $\begin{array}{l}\text { Maximum } \\
\text { Contaminant } \\
\text { Level Goal } \\
(\mathrm{MCLG}) \text { in } \\
\mathrm{mg} / \mathrm{L}\end{array}$ & $\begin{array}{l}\text { Maximum } \\
\text { Contaminant } \\
\text { Level } \\
(\mathrm{MCL}) \quad \text { in } \\
\mathrm{mg} / \mathrm{L}\end{array}$ & & & \\
\hline Antimony & 0.006 & 0.006 & - & $\begin{array}{ll}\text { Increase } & \text { in } \quad \text { blood } \\
\text { cholesterol; } & \text { decrease in } \\
\text { blood sugar } & \end{array}$ & $\begin{array}{l}\text { Discharge from petroleum } \\
\text { refineries; fire retardants; } \\
\text { ceramics; electronics; solder }\end{array}$ \\
\hline Arsenic & 0 & 0.01 & 0.05 & $\begin{array}{l}\text { Skin damage or problems } \\
\text { with circulatory systems, } \\
\text { and may have increased risk } \\
\text { of getting cancer }\end{array}$ & $\begin{array}{l}\text { Erosion of natural deposits; } \\
\text { runoff from orchards, runoff } \\
\text { from glass and electronics } \\
\text { production wastes }\end{array}$ \\
\hline Barium & 2 & 2 & - & Increase in blood pressure & $\begin{array}{l}\text { Discharge of drilling wastes; } \\
\text { discharge } \\
\text { refineries; erosion of natural } \\
\text { deposits }\end{array}$ \\
\hline Beryllium & 0.004 & 0.004 & - & Intestinal lesions & $\begin{array}{llr}\text { Discharge } & \text { from } & \text { metal } \\
\text { refineries and coal-burning } & \\
\text { factories; discharge } & \text { from } \\
\text { electrical, aerospace, and } & \text { defense industries }\end{array}$ \\
\hline Cadmium & 0.005 & 0.005 & 0.003 & Kidney damage & $\begin{array}{l}\text { Corrosion of galvanized pipes; } \\
\text { erosion of natural deposits; } \\
\text { discharge from metal } \\
\text { refineries; runoff from waste } \\
\text { batteries and paints }\end{array}$ \\
\hline
\end{tabular}




\begin{tabular}{|c|c|c|c|c|c|}
\hline $\begin{array}{l}\text { Total } \\
\text { Chromium }\end{array}$ & 0.1 & 0.1 & 0.05 as $\mathrm{Cr}(\mathrm{VI})$ & Allergic dermatitis & $\begin{array}{l}\text { Discharge from steel and pulp } \\
\text { mills; erosion of natural } \\
\text { deposits }\end{array}$ \\
\hline Copper & 1.3 & 1.3 & - & $\begin{array}{l}\text { Short term exposure: } \\
\text { Gastrointestinal distress } \\
\text { Long term exposure: Liver } \\
\text { or kidney damage } \\
\text { People with Wilson's } \\
\text { Disease should consult their } \\
\text { personal doctor if the } \\
\text { amount of copper in their } \\
\text { water exceeds the action } \\
\text { level }\end{array}$ & $\begin{array}{l}\text { Corrosion of household } \\
\text { plumbing systems; erosion of } \\
\text { natural deposits }\end{array}$ \\
\hline Lead & zero & 0.015 & 0.01 & $\begin{array}{l}\text { Infants and children: Delays } \\
\text { in physical or mental } \\
\text { development; children } \\
\text { could show slight deficits in } \\
\text { attention span and learning } \\
\text { abilities } \\
\text { Adults: Kidney problems; } \\
\text { high blood pressure }\end{array}$ & $\begin{array}{l}\text { Corrosion of household } \\
\text { plumbing systems; erosion of } \\
\text { natural deposits }\end{array}$ \\
\hline Mercury & 0.002 & 0.002 & 0.001 & Kidney damage & $\begin{array}{l}\text { Erosion of natural deposits; } \\
\text { discharge from refineries and } \\
\text { factories; runoff from landfills } \\
\text { and croplands }\end{array}$ \\
\hline Selenium & 0.05 & 0.05 & - & $\begin{array}{l}\text { Hair or fingernail loss; } \\
\text { numbness in fingers or toes; } \\
\text { circulatory problems }\end{array}$ & $\begin{array}{l}\text { Discharge from petroleum } \\
\text { refineries; erosion of natural } \\
\text { deposits; discharge from mines }\end{array}$ \\
\hline Thallium & 0.0005 & 0.002 & - & $\begin{array}{l}\text { Hair loss; changes in blood; } \\
\text { kidney, intestine, or liver } \\
\text { problems }\end{array}$ & $\begin{array}{l}\text { Leaching from ore-processing } \\
\text { sites; discharge from } \\
\text { electronics, glass, and drug } \\
\text { factories }\end{array}$ \\
\hline
\end{tabular}


Table 2. Chromite mineral commodity summaries of 2016 by United States Geological Survey [12]

\begin{tabular}{|l|l|l|l|}
\hline \multirow{2}{*}{ Country } & \multicolumn{2}{|l|}{$\begin{array}{l}\text { Mine production for the year 2014 and } \\
\left(\times 10^{3} \text { metric ton }\right)\end{array}$} & $\begin{array}{l}\text { Shipping grade reserves } \\
\left(\times 10^{3} \text { metric ton }\right)\end{array}$ \\
\cline { 2 - 4 } & 2014 & 2015 & \\
\hline Kazakhstan & 3700 & 3800 & 230000 \\
\hline South Africa & 12000 & 15000 & 200000 \\
\hline India & 3540 & 3500 & 54000 \\
\hline Turkey & 2600 & 3600 & Not applicable \\
\hline Other countries & 4,590 & & Not applicable \\
\hline United States & Not applicable & Not applicable & 620 \\
\hline World total (rounded) & 26,400 & 27,000 & $>480,000$ \\
\hline
\end{tabular}


Table 3. List of foods contain chromium. [9]

\begin{tabular}{|l|l|}
\hline Food & Cr content $(\mu \mathrm{g}$ per $100 \mathrm{~g}$ food $)$ \\
\hline Brewer's yeast & 112 \\
\hline Liver & 55 \\
\hline Whole-wheat bread & 42 \\
\hline Wheat bran & 38 \\
\hline Rye bread & 30 \\
\hline Potato & 24 \\
\hline Wheat germ & 23 \\
\hline Egg & 20 \\
\hline Green pepper & 19 \\
\hline Apple & 14 \\
\hline Butter & 13 \\
\hline Cheese & 13 \\
\hline Banana & 10 \\
\hline Carrot & 9 \\
\hline Navy bean, dry & 8 \\
\hline Fresh fish & 5 \\
\hline Orange & 4 \\
\hline Blueberry & 5 \\
\hline Green bean & 4 \\
\hline Cabbage & \\
\hline
\end{tabular}


Table 4. Chromium content in human body. [7]

\begin{tabular}{|l|l|}
\hline Organ/Tissue/Fluid & Total Chromium concentration \\
\hline Serum & $0.01-0.38 \mu \mathrm{g} / \mathrm{L}$ \\
\hline Blood & $0.12-0.67 \mu \mathrm{g} / \mathrm{L}$ \\
\hline Urine & $0.05-1.80 \mu \mathrm{g} / \mathrm{L}$ \\
\hline Saliva & $0.55-0.70 \mu \mathrm{g} / \mathrm{L}$ \\
\hline Breast milk & $0.06-1.56 \mu \mathrm{g} / \mathrm{L}$ \\
\hline Lung & $130-1375 \mu \mathrm{g} / \mathrm{kg}$ \\
\hline Liver & $5-15 \mu \mathrm{g} / \mathrm{kg}$ \\
\hline Spleen & $7-29 \mu \mathrm{g} / \mathrm{kg}$ \\
\hline Nail & $0.52-172.92 \mathrm{mg} / \mathrm{kg}$ \\
\hline Hair & $0.234-3.80 \mathrm{mg} / \mathrm{kg}$ \\
\hline Teeth & $7.20-35.00 \mathrm{mg} / \mathrm{kg}$ \\
\hline Skeleton & $5-15 \mu \mathrm{g} / \mathrm{kg}$ \\
\hline Muscle & $5-10 \mu \mathrm{g} / \mathrm{kg}$ \\
\hline Skin & $50-200 \mu \mathrm{g} / \mathrm{kg}$ \\
\hline Average amount per human body & $0.4-6 \mathrm{mg}$ \\
\hline
\end{tabular}


Table 5. List of isolates from different sources and their applications in $\mathrm{Cr}(\mathrm{VI})$ process.

\begin{tabular}{|c|c|c|c|}
\hline $\begin{array}{l}\mathrm{Cr}(\mathrm{VI}) \text { reducing } \\
\text { Biota }\end{array}$ & $\begin{array}{l}\text { Source of } \\
\text { Cr(VI) with } \\
\text { concentration }\end{array}$ & Reduction process and efficiency & Reference \\
\hline $\begin{array}{l}\text { Acenetobacter } \\
\text { calcoaciticus } \\
\text { isolated from } \\
\text { chromite mine }\end{array}$ & $\begin{array}{l}\text { Synthetic } \\
\mathrm{K}_{2} \mathrm{Cr}_{2} \mathrm{O}_{7} \\
\text { solution, } 100 \\
\text { mg/L }\end{array}$ & $\begin{array}{l}100 \mathrm{~mL} \text { Luria Bertani medium in } 250 \\
\mathrm{~mL} \text { Erlenmeyer flask; conditions: temp.- } \\
30{ }^{\circ} \mathrm{C}, 100 \mathrm{rpm} \text {, incubation time- } 24 \mathrm{hr} \\
\text { and } \mathrm{pH}-8 \text {; Efficiency- } 85 \%\end{array}$ & [84] \\
\hline $\begin{array}{l}\text { Fusarium genus } \\
\text { isolated from } \\
\text { tannery effluent }\end{array}$ & $\begin{array}{l}\text { Synthetic } \\
\mathrm{K}_{2} \mathrm{Cr}_{2} \mathrm{O}_{7} \\
\text { solution, } 10 \\
\text { mg/L }\end{array}$ & $\begin{array}{l}\text { Potato dextrose broth media in } 250 \mathrm{ml} \\
\text { Erlenmeyer flask; optimum condition: } \\
\text { temp.-25 }{ }^{\circ} \mathrm{C} \text {, incubation time- } 72 \mathrm{hr}, 120 \\
\mathrm{rpm} \text { and } \mathrm{pH}-5 \text {; Efficiency-100\% }\end{array}$ & [70] \\
\hline $\begin{array}{l}\text { Halomonas species } \\
\text { isolated from } \mathrm{Cr} \\
\text { contaminated soil }\end{array}$ & $\begin{array}{l}\text { Soil digested } \\
\text { Cr(VI) solution, } \\
18 \mathrm{mM}\end{array}$ & $\begin{array}{l}15 \mathrm{~g} \text { soil digested in } 30 \mathrm{~mL} \text { sterile water } \\
\text { in } 300 \mathrm{~mL} \text { bottle contains; (i) acetate } \\
\text { dependent biostimulated soil, (ii) acetate } \\
\text { dependent abiotic reduction, and (iii) } \\
\text { soil in water without acetate; Efficiency- } \\
100 \%\end{array}$ & [165] \\
\hline $\begin{array}{l}\text { Plant (Phragmites } \\
\text { australis and } \\
\text { Ailanthus altissima) }\end{array}$ & $\begin{array}{l}\text { Tap water, } 10 \\
\mathrm{mg} / \mathrm{L}\end{array}$ & $\begin{array}{l}\text { Pots in Greenhouse; conditions: temp.- } \\
20{ }^{\circ} \mathrm{C} \text {, average relative humidity- } 60 \% \text {, } \\
\text { irrigated time- } 360 \text { days, continuous flow } \\
\text { rate- } 0.2 \mathrm{~L} / \mathrm{min} \text { using peristaltic pump; } \\
\text { Efficiency: } 50 \% \text { for Phragmites } \\
\text { australis and } 40 \% \text { Ailanthus altissima }\end{array}$ & [136] \\
\hline $\begin{array}{l}\text { Amino modified } \\
\text { activated carbon } \\
\text { from native } \\
\text { Macadamia }\end{array}$ & \begin{tabular}{|l} 
Synthetic \\
$\mathrm{K}_{2} \mathrm{Cr}_{2} \mathrm{O}_{7}$ \\
solution, 10 \\
to $180 \mathrm{mg} / \mathrm{L}$
\end{tabular} & $\begin{array}{l}100 \mathrm{~mL} \text { beaker; conditions: } \mathrm{pH} \text {, contact } \\
\text { time, initial Cr(VI) concentration and } \\
\text { adsorbent dosage; Efficiency- } 100 \%\end{array}$ & {$[161]$} \\
\hline $\begin{array}{l}\text { Cellulosimicrobium } \\
\text { sp. and } \\
\text { Exiguobacterium } \\
\text { sp. isolated from } \\
\text { contaminated soil }\end{array}$ & $\begin{array}{l}\text { Synthetic } \\
\mathrm{K}_{2} \mathrm{Cr}_{2} \mathrm{O}_{7} \\
\text { solution, } 10 \\
\mathrm{mM}\end{array}$ & $\begin{array}{l}\text { DeLeo and Ehrlich medium; conditions: } \\
\text { incubation time- } 72 \mathrm{hr} \text {, temp- } 37^{\circ} \mathrm{C} \text { and } \\
200 \mathrm{rpm} \text {; Efficiency- } 45 \%\end{array}$ & [99] \\
\hline $\begin{array}{l}\text { Corynebacterium } \\
\text { paurometabolum } \\
\text { isolated from }\end{array}$ & \begin{tabular}{|l|} 
Synthetic \\
$\mathrm{K}_{2} \mathrm{Cr}_{2} \mathrm{O}_{7}$ \\
solution, $2 \mathrm{mM}$
\end{tabular} & $\begin{array}{l}\text { Vogel Bonner broth in } 100 \mathrm{ml} \\
\text { Erlenmeyer flask; optimum condition: }\end{array}$ & [90] \\
\hline
\end{tabular}




\begin{tabular}{|c|c|c|c|}
\hline $\begin{array}{l}\text { chromite mine } \\
\text { seepage }\end{array}$ & & $\begin{array}{l}\mathrm{pH}-7, \text { temp. }-35^{\circ} \mathrm{C} \text {, incubation time- } 8 \\
\text { days and } 120 \mathrm{rpm} \text {; Efficiency- } 62.5 \%\end{array}$ & \\
\hline $\begin{array}{l}\text { Alcaligenes faecalis } \\
\text { and } \\
\text { Pseudochrobactrum } \\
\text { saccharolyticum } \\
\text { isolated from } \\
\text { contaminated } \\
\text { Effluent }\end{array}$ & \begin{tabular}{|l|} 
Synthetic \\
$\mathrm{K}_{2} \mathrm{Cr}_{2} \mathrm{O}_{7}$ \\
solution, 10 and \\
$100 \mathrm{mg} / \mathrm{L} ;$ \\
Industrial \\
effluent, 10 \\
$\mathrm{mg} / \mathrm{L}$
\end{tabular} & $\begin{array}{l}\text { Luria Bertani culture medium in } 300 \mathrm{~mL} \\
\text { bottle at } 180 \mathrm{rpm} \text {; parameters: isolates } \\
\text { comparison, temp., nutrient supplements } \\
\text { and incubation time; Efficiency-100 \% } \\
\text { for both synthetic and effluent }\end{array}$ & {$[77]$} \\
\hline $\begin{array}{l}\text { Bacillus Cereus } \\
\text { isolated from } \\
\text { agricultural field, } \\
\text { MIC-1450 mg/L }\end{array}$ & \begin{tabular}{|l} 
Synthetic \\
$\mathrm{K}_{2} \mathrm{Cr}_{2} \mathrm{O}_{7}$ \\
solution, 100 \\
to $500 \mathrm{mg} / \mathrm{L}$
\end{tabular} & $\begin{array}{l}\text { 100mL Luria Bertani broth in } 250 \mathrm{ml} \\
\text { Erlenmeyer flask; conditions: temp.-30 } \\
{ }^{\circ} \mathrm{C} \text { and incubation time } 48 \mathrm{hr} \text {; } \\
\text { Efficiency-70\% }\end{array}$ & [106] \\
\hline $\begin{array}{l}\text { Anaerobic culture at } \\
\text { anode and } \\
\text { denitrifying } \\
\text { anaerobic mixed } \\
\text { cultures at cathode }\end{array}$ & $\begin{array}{l}\text { Synthetic } \\
\mathrm{K}_{2} \mathrm{Cr}_{2} \mathrm{O}_{7} \\
\text { solution, up to } \\
80 \mathrm{mg} / \mathrm{L}\end{array}$ & $\begin{array}{l}\text { Microbial fuel cell with each } \\
\text { compartment volume- } 230 \mathrm{~mL}, \\
\text { electrode-graphite, } \\
\text { Nutrient media [196]; Efficiency-70\% }\end{array}$ & {$[175]$} \\
\hline $\begin{array}{l}\text { Mixture of } \\
\text { mesophilic } \\
\text { anaerobic digested } \\
\text { sludge and aerobic } \\
\text { activated sludge } \\
\text { from WTP at a ratio } \\
\text { of } 1: 1\end{array}$ & $\begin{array}{l}\text { Ground water, } 1 \\
\text { to } 30 \mathrm{mg} / \mathrm{L} ; \\
\mathrm{Cr}(\mathrm{VI}) \text { conc. } \\
\text { manage by } \\
\text { adding } \mathrm{K}_{2} \mathrm{Cr}_{2} \mathrm{O}_{7}\end{array}$ & $\begin{array}{l}\text { Two SBR fed with groundwater of } 3 \mathrm{~L} \\
\text { (total volume }=5 \mathrm{~L} \text { ) with anaerobic and } \\
\text { anoxic; conditions; design parameters: } \\
\text { feeding time- } 0.5 \mathrm{hr} \text {, reaction time- } 22 \mathrm{hr} \text {, } \\
\text { settling time- } 1 \mathrm{hr} \text {, decanting time- } 0.5 \mathrm{hr} \text {, } \\
\text { sludge retention time- } 10 \text { days and } \\
\text { hydraulic residence time- } 1.7 \text { days; } \\
\text { Efficiency- } 99 \% \text { up to initial Cr(VI) } \\
\text { conc. } 10 \mathrm{mg} / \mathrm{L}\end{array}$ & [167] \\
\hline $\begin{array}{l}\text { Desulfovibrio } \\
\text { vulgaris strain } \\
\text { isolated from } \\
\text { subsurface }\end{array}$ & $\begin{array}{l}\text { Ground water, } \\
50 \mu \mathrm{M} ; \mathrm{Cr}(\mathrm{VI}) \\
\text { conc. manage } \\
\text { by adding } \\
\mathrm{K}_{2} \mathrm{Cr}_{2} \mathrm{O}_{7}\end{array}$ & $\begin{array}{l}500 \mathrm{~mL} \text { lactate-sulfate medium media in } \\
1 \mathrm{~L} \text { glass bottle modified to serum } \\
\text { bottle; conditions: presence of hematite } \\
\text { or Al-goethite or nontronite (NAu-2); } \\
\text { Efficiency-100 \% in hematite }\end{array}$ & {$[114]$} \\
\hline $\begin{array}{l}\text { Pseudomonas sp. } \\
\text { isolated from } \\
\text { industrial soil }\end{array}$ & $\begin{array}{l}\text { Synthetic } \\
\mathrm{K}_{2} \mathrm{Cr}_{2} \mathrm{O}_{7} \\
\text { solution, up to } \\
150 \mathrm{mg} / \mathrm{L}\end{array}$ & $\begin{array}{l}\text { Nutrient broth in } 250 \mathrm{ml} \text { Erlenmeyer } \\
\text { flask; conditions: pH- 6, initial Cr(VI) } \\
\text { conc.-100 mg/L, incubation time-120 hr } \\
\text { and temp. } 28^{\circ} \mathrm{C} \text {; Efficiency- } 60 \%\end{array}$ & [83] \\
\hline $\begin{array}{l}\text { Bacillus subtilis } \\
\text { isolated from } \\
\text { tannery effluent } \\
\text { contaminated }\end{array}$ & $\begin{array}{l}\text { Synthetic } \\
\mathrm{K}_{2} \mathrm{Cr}_{2} \mathrm{O}_{7} \\
\text { solution, } 50 \\
\text { mg/L }\end{array}$ & $\begin{array}{l}\text { CA-M9 Minimal Media with 5\% seed } \\
\text { culture; conditions: } \mathrm{pH}-9 \text {, temp.-30 }{ }^{\circ} \mathrm{C} \\
\text { and } 100 \text { rpm; Efficiency-100\% }\end{array}$ & [105] \\
\hline
\end{tabular}




\begin{tabular}{|c|c|c|c|}
\hline soil & & & \\
\hline $\begin{array}{l}\text { Sporosarcina } \\
\text { saromensi isolated } \\
\text { from intertidal } \\
\text { zones at low tide }\end{array}$ & $\begin{array}{l}\text { Synthetic } \\
\mathrm{K}_{2} \mathrm{Cr}_{2} \mathrm{O}_{7} \\
\text { solution, up } \\
\text { to150 mg/L }\end{array}$ & $\begin{array}{l}\text { 216LB medium and } 4 \% \text { seed inoculums } \\
\text { in Erlenmeyer flask, } 200 \mathrm{rpm} \text { and } 24 \mathrm{hr} \\
\text { incubation; parameters: initial } \mathrm{Cr}(\mathrm{VI}) \\
\text { concentration, } \mathrm{pH} \text { and temperature; } \\
\text { Efficiency-100\% }\end{array}$ & [100] \\
\hline $\begin{array}{l}\text { Chlorella vulgaris } \\
\text { laboratory culture }\end{array}$ & $\begin{array}{l}\text { Tannery } \\
\text { wastewater, } \\
3.22 \mathrm{mg} / \mathrm{L}\end{array}$ & $\begin{array}{l}100 \mathrm{~mL} \text { algal culture medium in } 250 \mathrm{~mL} \\
\text { Erlenmeyer flask at temp. } 28^{\circ} \mathrm{C} \text { under } \\
\text { fluorescent lights } 150-300 \mu \mathrm{mol} \cdot \mathrm{m}^{-2} . \mathrm{s}^{-1} \\
\text { photons; Efficiency- } 100 \%\end{array}$ & [143] \\
\hline $\begin{array}{l}\text { Penicillium } \\
\text { commune, } \\
\text { Paecilomyces } \\
\text { lilacinus, } \\
\text { Cladosporium } \\
\text { perangustum, } \\
\text { Cladosporium } \\
\text { perangustum and } \\
\text { Fusarium equiseti } \\
\text { isolated from Soil, } \\
\text { sludge and } \\
\text { wastewater samples }\end{array}$ & $\begin{array}{l}\text { Tannery } \\
\text { wastewater, } \\
9.86 \mathrm{mg} / \mathrm{L}\end{array}$ & $\begin{array}{l}1 \mathrm{~L} \text { bioreactor }(12 \mathrm{~cm} \text { in diameter and } \\
20 \mathrm{~cm} \text { in height) with modified minimal } \\
\text { medium, glucose and ammonium nitrate } \\
\text { supplemented, temp. }-28^{\circ} \mathrm{C} \text { and } \mathrm{pH}-4 \text {; } \\
\text { Efficiency- } 73 \% \text { in } 12 \mathrm{hr}\end{array}$ & [75] \\
\hline $\begin{array}{l}\text { Aspergillus niger, } \\
\text { A. flavus, A. } \\
\text { fumigatus, A. } \\
\text { nidulans, } A \text {. } \\
\text { heteromorphus, } A \text {. } \\
\text { foetidus, and } A \text {. } \\
\text { viridinutans isolated } \\
\text { from soil }\end{array}$ & $\begin{array}{l}\text { Tannery } \\
\text { wastewater, } 290 \\
\mathrm{mg} / \mathrm{L}\end{array}$ & $\begin{array}{l}50 \mathrm{~mL} \text { flask; optimum conditions: } \mathrm{pH}-3 \text {, } \\
\text { fungi biomass- } 4 \mathrm{~g}, \text { initial } \mathrm{Cr}(\mathrm{VI}) \\
\text { concentration- } 18 \mathrm{mg} / \mathrm{L} \text { and strain } A . \\
\text { niger; Efficiency- } 96.3 \%\end{array}$ & [128] \\
\hline $\begin{array}{l}\text { Laboratory culture } \\
\text { Arthrobacter } \\
\text { viscosus }\end{array}$ & $\begin{array}{l}\text { Synthetic } \\
\mathrm{K}_{2} \mathrm{Cr}_{2} \mathrm{O}_{7} \\
\text { solution, } \\
100 \mathrm{mg} / \mathrm{L} \text { for } \\
\text { batch and } \\
25 \mathrm{mg} / \mathrm{L} \text { for } \\
\text { column }\end{array}$ & $\begin{array}{l}100 \mathrm{~mL} \text { media in } 250 \mathrm{~mL} \text { Erlenmeyer } \\
\text { flasks at } 150 \mathrm{rpm} \text {; } \\
\text { Parameters: } \mathrm{pH} \text {, biomass conc., and } \\
\text { contact time; star shaped column } 17 \mathrm{~mm} \\
\text { external diameter and height of } 10 \mathrm{~mm} \text {, } \\
\text { flow rate- } 10 \mathrm{~mL} / \mathrm{min} \text { up flow method for } \\
120 \mathrm{hr} \text { and } \mathrm{pH}-2 \text { at room temp.; } \\
\text { Efficiency- } 100 \% \text { (batch study) and in } \\
\text { column equilibrium achieved in } 450 \mathrm{~min} \\
\text { with } \mathrm{Cr} \text { uptake } 20.37 \mathrm{mg} / \mathrm{g}\end{array}$ & [110] \\
\hline
\end{tabular}




\begin{tabular}{|c|c|c|c|}
\hline $\begin{array}{l}\text { Bacillus pumilus, } \\
\text { Pseudomonas } \\
\text { doudoroffii and } \\
\text { Exiguobacterium } \\
\text { isolated from } \\
\text { tannery effluent }\end{array}$ & \begin{tabular}{|l} 
Synthetic \\
$\mathrm{K}_{2} \mathrm{CrO}_{4}$ solution, \\
100 to 1000 \\
$\mathrm{mg} / \mathrm{L}$
\end{tabular} & $\begin{array}{l}\text { DeLeo and Ehrlich medium; } \\
\text { optimum conditions: } 150 \mathrm{rpm} \text {, temp.-37 } \\
{ }^{\circ} \mathrm{C} \text {, incubation time- } 24 \mathrm{hr}, \mathrm{pH}-7 \text { and } \\
\text { initial } \mathrm{Cr}(\mathrm{VI}) \\
\text { concentration of } 100 \mathrm{mg} / \mathrm{L} \text {; Efficiency- } \\
82.4,71.2 \text { and } 52.1 \% \text { by } \text { B. pumilus, } P \text {. } \\
\text { doudoroffii and Exiguobacterium }\end{array}$ & [82] \\
\hline $\begin{array}{l}\text { Acinetobacter sp. } \\
\text { isolated from } \\
\text { aerator liquid of } \\
\text { activated sludge } \\
\text { process }\end{array}$ & $\begin{array}{l}\text { Synthetic } \\
\mathrm{K}_{2} \mathrm{Cr}_{2} \mathrm{O}_{7} \\
\text { solution, } \\
200 \mathrm{mg} / \mathrm{L}\end{array}$ & $\begin{array}{l}100 \mathrm{~mL} \text { LB media in Erlenmeyer flasks; } \\
\text { conditions: temp.- } 37^{\circ} \mathrm{C} \text {, } 150 \mathrm{rpm} \text { and } \\
\text { initial } \mathrm{Cr}(\mathrm{VI})-200 \mathrm{mg} / \mathrm{L} \text {; Efficiency-100 } \\
\%\end{array}$ & [94] \\
\hline $\begin{array}{l}\text { Pseudochrobactrum } \\
\text { saccharolyticum } \\
\text { isolated from } \\
\text { chromium } \\
\text { contaminated site }\end{array}$ & $\begin{array}{l}\text { Synthetic } \\
\mathrm{K}_{2} \mathrm{Cr}_{2} \mathrm{O}_{7} \\
\text { solution, } \\
55 \text { to } 360 \mathrm{mg} / \mathrm{L}\end{array}$ & $\begin{array}{l}\text { Modified Luria-Bertani media; optimum } \\
\text { conditions: } \mathrm{pH}-8.3 \text {, initial Cr(VI) conc.- } \\
55 \mathrm{mg} / \mathrm{L}, \mathrm{NaCl}-20 \mathrm{mg} / \mathrm{L} \text {, and } 1.47 \times 10^{9} \\
\text { cells } / \mathrm{mL} \text {; Efficiency-100 \% in } 96 \mathrm{hr}\end{array}$ & [85] \\
\hline $\begin{array}{l}\text { Anaerobic methane } \\
\text { oxidizing archaea } \\
\text { from activated } \\
\text { sludge of a WTP }\end{array}$ & $\begin{array}{l}\text { Synthetic } \\
\mathrm{K}_{2} \mathrm{Cr}_{2} \mathrm{O}_{7} \\
\text { solution, } \\
0.01 \mathrm{mM}\end{array}$ & $\begin{array}{l}3 \mathrm{~L} \text { laboratory glass reactor with } 2 \mathrm{~L} \\
\text { Mineral salt media sparged with } \mathrm{N}_{2}-\mathrm{CO}_{2} \\
\text { at } 35^{\circ} \mathrm{C} \text { and } \mathrm{pH} \text { between } 7.0 \text { and } \\
8.5 ; \text { Efficiency-100\% }\end{array}$ & [169] \\
\hline $\begin{array}{l}\text { A. flavus isolated } \\
\text { from contaminated } \\
\text { soil sample }\end{array}$ & $\begin{array}{l}\text { Synthetic } \\
\mathrm{K}_{2} \mathrm{Cr}_{2} \mathrm{O}_{7} \\
\text { solution, } \\
10 \text { to } 60 \mathrm{mg} / \mathrm{L}\end{array}$ & $\begin{array}{l}50 \mathrm{ml} \text { of nutrient broth medium in } 250 \\
\text { ml screw capped Erlenmeyer flasks } \\
\text { incubated at } 120 \mathrm{rpm} \text { and } 30^{\circ} \mathrm{C} ; \\
\text { parameters: initial metal ions } \\
\text { concentration and incubation period and } \\
\text { pH; Efficiency-71\% }\end{array}$ & [129] \\
\hline $\begin{array}{l}\text { Trichoderma } \\
\text { asperellum isolated } \\
\text { from contaminated } \\
\text { site of non-ferrous } \\
\text { metal mine }\end{array}$ & $\begin{array}{l}\text { Synthetic } \\
\mathrm{K}_{2} \mathrm{Cr}_{2} \mathrm{O}_{7} \\
\text { solution, } 10 \\
\text { mg/L }\end{array}$ & $\begin{array}{l}200 \mathrm{~mL} \text { liquid medium at temp. } 28^{\circ} \mathrm{C} \text {, } \\
150 \mathrm{rpm}, \mathrm{pH}-6.8 \text { to } 7.27 \text { and incubation } \\
\text { time- } 96 \mathrm{hr} \text {; Efficiency-100\% }\end{array}$ & [184] \\
\hline $\begin{array}{l}\text { Leucobacter } \\
\text { komagatae and } \\
\text { Leucobacter albus } \\
\text { isolated from } \\
\text { contaminated soil of } \\
\text { tannery factory }\end{array}$ & $\begin{array}{l}\text { Synthetic } \\
\mathrm{K}_{2} \mathrm{Cr}_{2} \mathrm{O}_{7} \\
\text { solution, } 400 \\
\text { mg/L }\end{array}$ & $\begin{array}{l}100 \mathrm{ml} \text { Luria-Bertani medium } \\
\text { in Erlenmeyer flasks at temp.-35 }{ }^{\circ} \mathrm{C} \text { and } \\
160 \mathrm{rpm} \text {; conditions: aerobic, facultative } \\
\text { anaerobic (without shaking), and strict } \\
\text { anaerobic; Efficiency-100\% for } \\
\text { facultative anaerobic, } 33.3 \% \text { for aerobic } \\
\text { and } 65.4 \% \text { strict anaerobic } \\
\text { Incubation in } 96 \mathrm{hr}\end{array}$ & [185] \\
\hline
\end{tabular}




\begin{tabular}{|c|c|c|c|}
\hline $\begin{array}{l}\text { Anaerobic activated } \\
\text { sludge as } \\
\text { inoculums, } \\
\text { Gamma- } \\
\text { proteobacteria } \\
\text { found in post } \\
\text { operation study }\end{array}$ & $\begin{array}{l}\text { Synthetic } \\
\mathrm{K}_{2} \mathrm{Cr}_{2} \mathrm{O}_{7} \\
\text { solution, } 20 \\
\text { mg/L }\end{array}$ & $\begin{array}{l}\text { Dual-chamber MFC, volume- } 70 \mathrm{~mL} \text {, } \\
\text { gastight, separated by proton exchange } \\
\text { membrane, Graphite sheet as electrodes; } \\
\text { Efficiency-79\% ex-situ and } 20 \% \text { in-situ }\end{array}$ & [177] \\
\hline $\begin{array}{l}\text { Stock culture } \\
\text { Pseudomonas } \\
\text { mendocina, } \\
\text { MIC-25 mg/L }\end{array}$ & $\begin{array}{l}\text { Synthetic } \\
\mathrm{K}_{2} \mathrm{Cr}_{2} \mathrm{O}_{7} \\
\text { solution, } 10 \text { to } \\
25 \mathrm{mg} / \mathrm{L}\end{array}$ & $\begin{array}{l}\text { 100mL triptic soy broth in } 250 \mathrm{~mL} \\
\text { flasks incubated at } 37{ }^{\circ} \mathrm{C} \text { and } 125 \mathrm{rpm} \text {; } \\
\text { optimum conditions: } \mathrm{pH}-6 \text {, initial } \mathrm{Cr}(\mathrm{VI}) \\
\text { concentration- } 10 \mathrm{mg} / \mathrm{L} \text {, incubation time } \\
-24 \mathrm{hr} \text { and galactronic acid; Efficiency- } \\
100 \%\end{array}$ & [81] \\
\hline $\begin{array}{l}\text { Acenetobacter } \\
\text { calcoaciticus } \\
\text { isolated from } \\
\text { mining area, MIC- } \\
1000 \mathrm{mg} / \mathrm{L}\end{array}$ & $\begin{array}{l}\text { Synthetic } \\
\mathrm{K}_{2} \mathrm{Cr}_{2} \mathrm{O}_{7} \\
\text { solution, } 100 \\
\text { mg/L }\end{array}$ & $\begin{array}{l}100 \mathrm{~mL} \text { Luria Bertani broth media in } \\
250 \mathrm{~mL} \text { Erlenmeyer flasks; optimum } \\
\text { conditions: } \mathrm{pH}-8 \text {, temp.-30 }{ }^{\circ} \mathrm{C} \text {, } \\
\text { incubation time-24hr and } 100 \mathrm{rpm} \text {; } \\
\text { Efficiency- } 89 \%\end{array}$ & [186] \\
\hline $\begin{array}{l}\text { Plant species } \\
\text { Phragmites } \\
\text { australis, Salix } \\
\text { viminalis and } \\
\text { Ailanthus altissima }\end{array}$ & $\begin{array}{l}\text { Synthetic } \\
\mathrm{Na}_{2} \mathrm{Cr}_{2} \mathrm{O}_{7} \\
\text { solution, } 10 \\
\text { m/L }\end{array}$ & $\begin{array}{l}\text { Phytoremediation; } 2 \mathrm{~L} \text { pots filled with } \\
\text { clay soil irrigated continuously with } \\
\text { flow rate of } 0.2 \mathrm{~L} / \mathrm{min} \text {, using a peristaltic } \\
\text { pump for } 360 \text { days; Efficiency-56 \% } \\
\text { with Phragmites, } 70 \% \text { with Salix }\end{array}$ & [135] \\
\hline $\begin{array}{l}\text { Arthrobacter } \\
\text { isolated from } \\
\text { chromite mine } \\
\text { overburden }\end{array}$ & $\begin{array}{l}\text { Chromite mine } \\
\text { effluents, } 60 \\
\mu \mathrm{M}\end{array}$ & $\begin{array}{l}\text { Cell-free chromate reductase enzyme; } \\
\text { conditions: } 120 \mathrm{rpm}, \mathrm{pH}-6.5 \text { to } 7.5 \text { and } \\
\text { temperature } 35^{\circ} \mathrm{C} \text {; Efficiency-> } 75 \% \\
\text { with NADH }\end{array}$ & [108] \\
\hline $\begin{array}{l}\text { Nesterenkonia sp. } \\
\text { isolated from } \\
\text { effluents of } \\
\text { tanneries, MIC-600 } \\
\text { mM }\end{array}$ & $\begin{array}{l}\text { Synthetic } \\
\mathrm{K}_{2} \mathrm{Cr}_{2} \mathrm{O}_{7} \\
\text { solution, } 0.2 \\
\mathrm{mM}\end{array}$ & $\begin{array}{l}25 \mathrm{~mL} \text { of Nutrient } \\
\text { broth medium in } 100 \mathrm{~mL} \text { Erlenmeyer } \\
\text { flasks; conditions: incubation time- } 24 \\
\text { hr, temp.-35 }{ }^{\circ} \mathrm{C} \text { and } 100 \mathrm{rpm} \text {; } \\
\text { Efficiency-100\% }\end{array}$ & [187] \\
\hline $\begin{array}{l}\text { Halomonas genus } \\
\text { isolated from Soap } \\
\text { Lake }\end{array}$ & $\begin{array}{l}\text { Synthetic } \\
\mathrm{K}_{2} \mathrm{Cr}_{2} \mathrm{O}_{7} \\
\text { solution, } 0.1 \\
\mathrm{mM}\end{array}$ & $\begin{array}{l}100 \mathrm{~mL} \text { Modified Soap Lake Basal } \\
\text { Media in } 150 \mathrm{~mL} \text { serum bottles; } \\
\text { conditions: } \mathrm{pH}-9 \text {, } \\
130 \mathrm{rpm} \text { and temp- } 35^{\circ} \mathrm{C} \text {; } \\
\text { Efficiency- } 80 \% \text { in } 25 \text { days }\end{array}$ & [188] \\
\hline
\end{tabular}




\begin{tabular}{|c|c|c|c|}
\hline $\begin{array}{l}\text { Stenorophomonas } \\
\text { maltophilia isolated } \\
\text { from feather } \\
\text { disposal site grown } \\
\text { in Feather meal } \\
\text { broth }\end{array}$ & \begin{tabular}{|l} 
Synthetic \\
$\mathrm{K}_{2} \mathrm{Cr}_{2} \mathrm{O}_{7}$ \\
solution, 50 and \\
$100 \mathrm{mg} / \mathrm{L}$
\end{tabular} & $\begin{array}{l}\text { Feather protein hydrolysate used for } \\
\text { reduction } 50 \mathrm{ml} \text { of peptone water at } \\
\text { temp-35 }{ }^{\circ} \mathrm{C} \text { and } 125 \mathrm{rpm} \text { for } 1 \mathrm{hr} \text {; } \\
\text { Efficiency-78\% }\end{array}$ & [93] \\
\hline $\begin{array}{l}\text { Bacillus cereus } \\
\text { isolated from soil } \\
\text { sample }\end{array}$ & $\begin{array}{l}\text { Tannery } \\
\text { effluent, total } \\
\text { chromium } 2.4 \\
\mathrm{mg} / \mathrm{L}\end{array}$ & $\begin{array}{l}100 \mathrm{~mL} \text { of sterilized tannery effluent } \\
\text { including } 10 \mathrm{~mL} \text { inoculums in } 250 \mathrm{~mL} \\
\text { Erlenmeyer flasks; conditions: temp.-35 } \\
{ }^{\circ} \mathrm{C} \text { and } 120 \mathrm{rpm} \text { for } 48 \mathrm{hr} \text {; Efficiency- } \\
92 \% \text { (immobilized cells) and } 73 \% \text { (free } \\
\text { cell) }\end{array}$ & [107] \\
\hline $\begin{array}{l}\text { Pseudomonas genus } \\
\text { Isolated from } \\
\text { circulating cooling } \\
\text { system of iron } \\
\text { and steel plant, } \\
\text { MIC- } 6.5 \mathrm{mmol} / \mathrm{L}\end{array}$ & $\begin{array}{l}\text { Synthetic } \\
\mathrm{K}_{2} \mathrm{CrO}_{4} \\
\text { solution, } 0.5 \text { to } \\
3 \mathrm{mmol} / \mathrm{L}\end{array}$ & $\begin{array}{l}100 \mathrm{~mL} \text { LB media in } 250 \mathrm{~mL} \\
\text { Erlenmeyer flask; optimum conditions: } \\
\text { pH-7 to 9, initial Cr(VI) concentration-3 } \\
\text { mmol/L, and inoculating dose-10 \%( } \\
\mathrm{v} / \mathrm{v}) \\
\text { for both growing cells and free cells; } \\
\text { Efficiency- } 100 \%\end{array}$ & [189] \\
\hline $\begin{array}{l}\text { Acinetobacter } \\
\text { isolated from } \\
\text { tanneries effluents }\end{array}$ & $\begin{array}{l}\text { Synthetic } \\
\mathrm{K}_{2} \mathrm{Cr}_{2} \mathrm{O}_{7} \\
\text { solution, } 50 \text { to } \\
200 \mathrm{mg} / \mathrm{L}\end{array}$ & $\begin{array}{l}\text { NB medium; conditions: } \mathrm{pH}-10 \text {, } \\
\text { temperature } 30^{\circ} \mathrm{C} \text {, and exposure time- } \\
72 \mathrm{hr} \text { and initial } \mathrm{Cr}(\mathrm{VI}) \text { concentration-50 } \\
\mathrm{mg} / \mathrm{L} \text {; Efficiency- } 100 \%\end{array}$ & [190] \\
\hline $\begin{array}{l}\text { Anaerobic sludge } \\
\text { collected from the } \\
\text { anaerobic digester } \\
\text { of the sewage } \\
\text { treatment plant }\end{array}$ & $\begin{array}{l}\text { Synthetic } \\
\mathrm{K}_{2} \mathrm{Cr}_{2} \mathrm{O}_{7} \\
\text { solution, } 75 \text { to } \\
300 \mathrm{mg} / \mathrm{L}\end{array}$ & $\begin{array}{l}\text { A two-chambered reactor, dimension ( } 8 \\
\text { cm diameter and } 10 \mathrm{~cm} \text { length; } 500 \mathrm{~mL} \\
\text { capacity and } 250 \mathrm{~mL} \text { working volume), } \\
\text { separated by proton exchange membrane } \\
\text { (Nafion } 117) \text {, plain carbon cloth as } \\
\text { electrode; Efficiency- } 100 \% \text { at } \mathrm{pH}-2 \text {, } \\
300 \mathrm{mg} / \mathrm{L}, 150 \mathrm{mg} / \mathrm{L} \text { and } 75 \mathrm{mg} / \mathrm{L} \\
\text { required } 1350 \mathrm{~min}, 750 \mathrm{~min} \text { and } 180 \\
\text { min, respectively }\end{array}$ & [174] \\
\hline $\begin{array}{l}\text { Staphylococcus } \\
\text { arlettae strain } \\
\text { isolated from } \\
\text { tannery effluent, } \\
\text { MIC-2000 } \mathrm{mg} / \mathrm{L} \text { in } \\
\text { liquid and } 5000 \\
\mathrm{mg} / \mathrm{L} \text { in solid media }\end{array}$ & $\begin{array}{l}\text { Synthetic } \\
\mathrm{K}_{2} \mathrm{Cr}_{2} \mathrm{O}_{7} \\
\text { solution, } 500 \\
\text { and } 1000 \mathrm{mg} / \mathrm{L}\end{array}$ & $\begin{array}{l}\text { Petri dishes containing tryptone soya } \\
\text { peptone (TS) media incubated at } 37 \mathrm{oC} \\
\text { and } 120 \mathrm{rpm} \text {; Efficiency- } 98 \% \text { and } 75 \% \\
\text { for initial } \mathrm{Cr}(\mathrm{VI}) \text { concentrations of } 500 \\
\text { and } 1000 \mathrm{mg} / \mathrm{L} \text {, respectively in } 120 \mathrm{hr}\end{array}$ & [88] \\
\hline
\end{tabular}




\begin{tabular}{|c|c|c|c|}
\hline $\begin{array}{l}\text { Bacilli } \text { sp. isolated } \\
\text { from tannery } \\
\text { effluent }\end{array}$ & \begin{tabular}{|l} 
Synthetic \\
$\mathrm{K}_{2} \mathrm{Cr}_{2} \mathrm{O}_{7}$ \\
solution, 21.5, \\
43 and \\
$80.63 \mathrm{mg} / \mathrm{L}$
\end{tabular} & $\begin{array}{l}50 \mathrm{~mL} \text { of Luria-Bertani media in } 250 \\
\mathrm{~mL} \text { Erlenmeyer flasks; Efficiency- } 87 \% \\
\text { for initial } \mathrm{Cr}(\mathrm{VI}) \text { conc. } 21.5 \mathrm{mg} / \mathrm{L} \text { in } 72 \\
\mathrm{hr}\end{array}$ & [191] \\
\hline $\begin{array}{l}\text { Acinetobacter } \\
\text { haemolyticus } \\
\text { isolated from textile } \\
\text { effluent }\end{array}$ & $\begin{array}{l}\text { Synthetic } \\
\mathrm{K}_{2} \mathrm{Cr}_{2} \mathrm{O}_{7} \\
\text { solution, } 10 \text { to } \\
100 \mathrm{mg} / \mathrm{L}\end{array}$ & $\begin{array}{l}100 \mathrm{~mL} \text { NB medium in } 250 \mathrm{~mL} \\
\text { Erlenmeyer flasks incubated at } 30^{\circ} \mathrm{C} \\
\text { and } 200 \mathrm{rpm} \text { for } 48 \mathrm{hr} \text {; Efficiency- }>90 \\
\%\end{array}$ & [95] \\
\hline $\begin{array}{l}\text { Arthrobacter sp. } \\
\text { and Pseudomonas } \\
\text { sp. isolated from } \\
\text { chromite } \\
\text { overburden }\end{array}$ & $\begin{array}{l}\text { Synthetic } \\
\mathrm{K}_{2} \mathrm{Cr}_{2} \mathrm{O}_{7} \\
\text { solution, } 2 \mathrm{mM}\end{array}$ & $\begin{array}{l}20 \mathrm{~mL} \text { Vogel Bonner (VB) broth and } \\
\text { modified KSC medium at pH- } 7 \text { in } 100 \\
\text { mL Erlenmeyer flask incubated at } 35^{\circ} \mathrm{C} \\
\text { and } 120 \mathrm{rpm} \text {; Efficiency-50\% in VB } \\
\text { broth and } 80 \% \text { KSC medium }\end{array}$ & [192] \\
\hline $\begin{array}{l}\text { Ochrobactrum } \\
\text { intermedium } \\
\text { isolated from } \\
\text { tannery effluent }\end{array}$ & $\begin{array}{l}\text { Synthetic } \\
\mathrm{K}_{2} \mathrm{CrO}_{4} \\
\text { Solution, } 100, \\
500 \text { and } 1000 \\
\mu \mathrm{g} / \mathrm{ml} \text {; } \\
\text { Industrial } \\
\text { sewage water } \\
\text { sample, } \mathrm{Cr}(\mathrm{VI})- \\
150 \mu \mathrm{g} / \mathrm{ml}, \mathrm{Fe}- \\
101 \mu \mathrm{g} / \mathrm{ml}, \\
\mathrm{Cu}-75 \mu \mathrm{g} / \mathrm{ml}, \\
\mathrm{Zn}-8 \mu \mathrm{g} / \mathrm{ml}, \mathrm{Ni}- \\
114 \mu \mathrm{g} / \mathrm{ml}, \mathrm{Co}- \\
4 \mu \mathrm{g} / \mathrm{ml}, \\
\mathrm{Pb}<1 \mu \mathrm{g} / \mathrm{ml}\end{array}$ & $\begin{array}{l}\text { DeLeo and Ehrlich (DE) } \\
\text { medium of pH-7 incubated at } 37 \mathrm{oC} \text { and } \\
150 \mathrm{rpm} \text {; Efficiency- } 97.1 \%, 95.5 \% \text { and } \\
91.2 \% \text { with initial } \mathrm{Cr}(\mathrm{VI}) \text { concentrations } \\
150,500 \text { and } 1000 \mu \mathrm{g} / \mathrm{ml} \text {, respectively, } \\
\text { in } 72 \mathrm{hr} \text { for industrial sewage water } \\
\text { sample; } \\
87 \%, 83 \% \text { and } 65 \% \text { with initial } \mathrm{Cr}(\mathrm{VI}) \\
\text { concentrations } 150,500 \text { and } 1000 \mu \mathrm{g} / \mathrm{ml} \text {, } \\
\text { respectively, in } 72 \mathrm{hr} \text { for artificial } \\
\text { sewage water sample }\end{array}$ & [193] \\
\hline $\begin{array}{l}\text { Lab culture } \\
\text { Cellulomonas } \\
\text { species isolated } \\
\text { from contaminated } \\
\text { soil preserved in } \\
\text { tryptic soy broth }\end{array}$ & $\begin{array}{l}\text { Synthetic } \\
\mathrm{K}_{2} \mathrm{CrO}_{4} \\
\text { Solution, } 7 \\
\text { mg/L }\end{array}$ & $\begin{array}{l}\text { 30-mL anaerobic culture tubes } \\
\text { sealed with butyl rubber stoppers and } \\
\text { aluminum } \\
\text { crimp seals, sucrose supplement as } \\
\text { carbon, electron shuttles anthraquinone- } \\
2,6 \text {-disulfonate AQDS and Fe(III); } \\
\text { Efficiency-100\% in } 25 \mathrm{hr} \text { in } \\
\text { sucrose+AQDS, >90\% in } 8 \mathrm{hr} \text { in } \\
\text { sucrose+AQDS+hematite }\end{array}$ & [101] \\
\hline $\begin{array}{l}\text { Halomonas sp. } \\
\text { isolated from } \\
\text { tannery effluent }\end{array}$ & $\begin{array}{l}\text { Synthetic } \\
\mathrm{K}_{2} \mathrm{CrO}_{4} \\
\text { Solution, } 50 \\
\mathrm{mg} / \mathrm{L}\end{array}$ & $\begin{array}{l}25 \mathrm{~mL} \text { of Luria Bertani medium in } 100 \\
\mathrm{~mL} \text { Erlenmeyer flasks at pH from } 6 \text { to } \\
11 \text {, incubated at } 30^{\circ} \mathrm{C} \text { and } 120 \mathrm{rpm} ; \\
\text { Efficiency- } 82 \% \text { in } 48 \mathrm{hr}\end{array}$ & [87] \\
\hline
\end{tabular}




\begin{tabular}{|c|c|c|c|}
\hline $\begin{array}{l}\text { Lab culture } \\
\text { Escherichia coli } \\
\text { basal medium }\end{array}$ & $\begin{array}{l}\text { Synthetic } \\
\mathrm{K}_{2} \mathrm{Cr}_{2} \mathrm{O}_{7} \\
\text { solution, } \\
10 \mathrm{mg} / \mathrm{L}\end{array}$ & $\begin{array}{l}250 \mathrm{ml} \text { serum bottles with butyl rubber } \\
\text { stoppers, Glucose as carbon source, and } \\
40 \mathrm{mg} / \mathrm{L} \mathrm{Fe}(\mathrm{III}) \text { dosage, incubated at } \\
32^{\circ} \mathrm{C} \text { and } 150 \mathrm{rpm} \text {; Efficiency- } 95 \%\end{array}$ & [102] \\
\hline $\begin{array}{l}\text { Bacillus sp. isolated } \\
\text { from soil samples of } \\
\text { land farming site }\end{array}$ & $\begin{array}{l}\text { Synthetic } \\
\mathrm{K}_{2} \mathrm{Cr}_{2} \mathrm{O}_{7} \\
\text { solution, } 2 \text { to } 8 \\
\mathrm{mg} / \mathrm{L}\end{array}$ & $\begin{array}{l}\text { Bioreactor columns of } 60 \mathrm{ml} \text { sterile } \\
\text { polypropylene syringes } \\
(2.5 \mathrm{~cm} \text { internal diameter and } 13.5 \mathrm{~cm} \\
\text { length) packed with } 45 \mathrm{~mL} \text { Celite, } \\
\text { Amberlite and Ca-Alginate in separate } \\
\text { columns, flow rate- } 3,6,10 \text {, and } 14 \\
\mathrm{~mL} / \mathrm{hr} \text { corresponding to retention times } \\
\text { of } 15,7.5,4.5 \text { and } 3.2 \text {, respectively; } \\
\text { Efficiency-98\% with cell-free extracts } \\
\text { and } 84 \% \text { with immobilized intact cells } \\
\text { for initial Cr(VI) conc. } 2 \text { to } 8 \mathrm{mg} / \mathrm{L} \text { at } \\
\text { flow rates } 3 \text { to } 6 \mathrm{~mL} / \mathrm{h} \text { with } \\
\text { immobilizers Celite and Ca-Alginate }\end{array}$ & {$[103]$} \\
\hline $\begin{array}{l}\text { Lab culture Bacillus } \\
\text { sphaericus in } \\
\text { Tryptic Soy Agar }\end{array}$ & $\begin{array}{l}\text { Synthetic } \\
\mathrm{K}_{2} \mathrm{Cr}_{2} \mathrm{O}_{7} \\
\text { solution, } 10 \text { to } \\
50 \mu \mathrm{M}\end{array}$ & $\begin{array}{l}10 \mathrm{~mL} \text { of mineral salts broth } \\
\text { supplemented with } 0.1 \% \text { glucose in } 100 \\
\text { mL of Erlenmeyer flask incubated at } 32 \\
{ }^{\circ} \mathrm{C} \text { and } 120 \mathrm{rpm} \text { with immobilizers: } \\
\text { Polyvinyl alginate, polyvinyl borate, } \\
\text { calcium alginate, agarose and agar-agar; } \\
\text { Efficiency-95\% in } 24 \mathrm{hr}\end{array}$ & {$[194]$} \\
\hline $\begin{array}{l}\text { Planococcus } \\
\text { maritimus isolated } \\
\text { from a coastal } \\
\text { region, } \\
\text { MIC-500 mg/L }\end{array}$ & $\begin{array}{l}\text { Synthetic } \\
\mathrm{K}_{2} \mathrm{Cr}_{2} \mathrm{O}_{7} \\
\text { solution, } 100 \text { to } \\
500 \mathrm{mg} / \mathrm{L}\end{array}$ & $\begin{array}{l}100 \text { mL Luria Bertani medium in } 250 \\
\text { mL Erlenmeyer flask; } \\
\text { optimum conditions: } \mathrm{pH}-7 \text {, temp.- } 355^{\circ} \mathrm{C} \text {, } \\
140 \mathrm{rpm} \text { and } 4 \% \mathrm{NaCl} \text {; Efficiency- } 100 \% \\
\text { with initial } \mathrm{Cr}(\mathrm{VI}) \text { conc. } 100 \text { and } 200 \\
\text { mg/L within } 24 \text { and } 28 \mathrm{hr} \text {, respectively }\end{array}$ & [195] \\
\hline $\begin{array}{l}\text { Providencia sp. } \\
\text { isolated from } \\
\text { contaminated sites } \\
\text { of chemical } \\
\text { industries, MIC- } \\
1000 \mathrm{mg} / \mathrm{L}\end{array}$ & $\begin{array}{l}\text { Synthetic } \\
\mathrm{K}_{2} \mathrm{Cr}_{2} \mathrm{O}_{7} \\
\text { solution, } 100 \text { to } \\
400 \mathrm{mg} / \mathrm{L}\end{array}$ & $\begin{array}{l}\text { Luria Bertani medium; Efficiency-100\% } \\
\text { with initial } \mathrm{Cr}(\mathrm{VI}) \text { conc. ranging from } \\
100 \text { to } 300 \mathrm{mg} / \mathrm{L} \text { and } 99 \% \text { with initial } \\
\mathrm{Cr}(\mathrm{VI}) \text { conc. } 400 \mathrm{mg} / \mathrm{L} \text {, at } \mathrm{pH}-7 \text { and } \\
\text { temperature } 37^{\circ} \mathrm{C}\end{array}$ & [197] \\
\hline $\begin{array}{l}\text { Halomonas } \\
\text { aquamarina } \mathrm{Sp} . \\
\text { isolated from } \\
\mathrm{Cr}(\mathrm{VI}) \text {-polluted }\end{array}$ & $\begin{array}{l}\text { Synthetic } \\
\mathrm{K}_{2} \mathrm{Cr}_{2} \mathrm{O}_{7} \\
\text { solution, } 0.2 \text { to } \\
3.0 \mathrm{mM}\end{array}$ & $\begin{array}{l}100 \mathrm{ml} \text { of YEPG-NaCl broth culture } \\
\text { medium, cell free extract, } \mathrm{pH}-6.5 \text { and } \\
\text { temperature- } 28 \mathrm{oC} \text {, NADH supplement, } \\
80 \mathrm{~g} / \mathrm{L} \mathrm{NaCl} \text {; Efficiency- } 81.5 \% \text { in } 24 \mathrm{hr}\end{array}$ & {$[86]$} \\
\hline
\end{tabular}




\begin{tabular}{|c|c|c|c|}
\hline $\begin{array}{l}\text { sediments, MIC-4 } \\
\mathrm{mM}\end{array}$ & & & \\
\hline $\begin{array}{l}\text { Sulfate reducing } \\
\text { sludge from an } \\
\text { anaerobic baffled } \\
\text { reactor treating acid } \\
\text { mine drainage }\end{array}$ & $\begin{array}{l}\text { Synthetic } \\
\mathrm{K}_{2} \mathrm{Cr}_{2} \mathrm{O}_{7} \\
\text { solution, } 5 \text { to } 50 \\
\text { mg/L }\end{array}$ & $\begin{array}{l}500 \mathrm{~mL} \text { glass column bioreactor filled } \\
\text { with elemental sulfur, flow rate-500 to } \\
1400 \mathrm{~mL} / \text { day, } \mathrm{HRT}-0.36 \text { to } 1 \text { day, } 56 \\
\mathrm{mg} / \mathrm{L} \\
\mathrm{KH}_{2} \mathrm{PO}_{4}, 110 \mathrm{mg} / \mathrm{L} \mathrm{NH} \mathrm{N}_{4} \mathrm{Cl}, 11 \mathrm{mg} / \mathrm{L} \\
\text { ascorbic acid and } 50 \mathrm{mg} / \mathrm{L} \text { yeast extract } \\
\text { and } 1000 \mathrm{mg} / \mathrm{L} \text { ethanol/acetate as } \\
\text { electron donor carbon source or COD; } \\
\text { Efficiency-97\% }\end{array}$ & [198] \\
\hline $\begin{array}{l}\text { Phytoremediation } \\
\text { by Halimione } \\
\text { Portulacoides } \\
\text { grown in Hoagland } \\
\text { nutrient solution }\end{array}$ & $\begin{array}{l}\text { Synthetic } \\
\mathrm{K}_{2} \mathrm{Cr}_{2} \mathrm{O}_{7} \\
\text { solution, } 15 \text { and } \\
\text { 30mg/L }\end{array}$ & $\begin{array}{l}\text { Greenhouse at temperature } 25^{\circ} \mathrm{C} \text {; } \\
\text { Efficiency->75\% }\end{array}$ & [137] \\
\hline $\begin{array}{l}\text { Pannonibacter } \\
\text { phragmitetus } \\
\text { isolated from } \\
\text { chromium } \\
\text { containing slag }\end{array}$ & $\begin{array}{l}\text { Synthetic } \\
\mathrm{K}_{2} \mathrm{Cr}_{2} \mathrm{O}_{7} \\
\text { solution, } 200 \\
\text { mg/L }\end{array}$ & $\begin{array}{l}20 \mathrm{~mL} \text { media in } 40 \mathrm{~mL} \text { sealed serum } \\
\text { bottles; parameters: carbon sources as } \\
\text { lactose, fructose, glucose, pyruvate, } \\
\text { citrate, formate, lactate, NADPH and } \\
\mathrm{NADH} \text { at } \mathrm{pH}-10 \text { and } 35^{\circ} \mathrm{C} \text {; Efficiency- } \\
100 \% \text { in } 24 \mathrm{hr}\end{array}$ & [199] \\
\hline $\begin{array}{l}\text { Rhodococcus } \\
\text { erythopolis isolated } \\
\text { from coal mine area }\end{array}$ & $\begin{array}{l}\text { Synthetic } \\
\mathrm{K}_{2} \mathrm{Cr}_{2} \mathrm{O}_{7} \\
\text { solution, } 1 \text { to } \\
100 \mathrm{mg} / \mathrm{L}\end{array}$ & $\begin{array}{l}\text { Optimum conditions: } \mathrm{pH}-5 \text { to } 7 \text {, } \\
\text { temperature- } 20 \text { to } 35^{\circ} \mathrm{C} \text {; Efficiency- } \\
89 \%\end{array}$ & [200] \\
\hline $\begin{array}{l}\text { Geobacter } \\
\text { metallireducens, } \\
\text { Desulfovibrio } \\
\text { desulfuricans and } \\
\text { Sulfurospirillum } \\
\text { barnesii }\end{array}$ & $\begin{array}{l}\text { Synthetic } \\
\mathrm{K}_{2} \mathrm{CrO}_{4} \\
\text { Solution, } 25 \text { to } \\
100 \mathrm{mM}\end{array}$ & $\begin{array}{l}20 \mathrm{~mL} \text { of culture in } 25 \mathrm{~mL} \text { serum bottle, } \\
\text { G. metallireducens grown on freshwater } \\
\text { acetate medium with nitrate, } D \text {. } \\
\text { desulfuricans and S.barnesii grown on } \\
\text { SES3 freshwater medium with lactate } \\
\text { and nitrate; Efficiency-72\% by } D . \\
\text { desulfuricans, and } S . \text { barnesii }\end{array}$ & [201] \\
\hline $\begin{array}{l}\text { Pseudomonas } \\
\text { aeruginosa isolated } \\
\text { from soil samples } \\
\text { collected } \\
\text { hydrocarbon } \\
\text { contaminated sites }\end{array}$ & $\begin{array}{l}\text { Effluent of hard } \\
\text { chrome plating } \\
\text { industry, } 2100 \\
\mathrm{mg} / \mathrm{L}\end{array}$ & $\begin{array}{l}5 \mathrm{~L} \text { reactor inoculated with } 50 \mathrm{ml} \text {, } \\
\text { hydraulic retention time- } 24 \mathrm{hr} \text {, inoculum } \\
\text { size- } 10 \% \text { v } / v(108 \text { cells } / \mathrm{mL}), \mathrm{pH}-7, \\
\text { temperature- } 32^{\circ} \mathrm{C} \text {, and flow rate- } 2.5 \\
\mathrm{~mL} / \mathrm{min} ; \text { Efficiency- } 84.85 \%\end{array}$ & [202] \\
\hline
\end{tabular}




\begin{tabular}{|c|c|c|c|}
\hline $\begin{array}{l}\text { Arthrobacter sp. } \\
\text { isolated from } \\
\text { metalliferous mine } \\
\text { overburden }\end{array}$ & \begin{tabular}{|l|} 
Synthetic \\
Cr(VI), $2 \mathrm{mM}$
\end{tabular} & $\begin{array}{l}20 \mathrm{~mL} \text { Vogel Bonner broth in } 100 \mathrm{~mL} \\
\text { Erlenmeyer flask, pH-7, temp.- } 35^{\circ} \mathrm{C} \text {, } \\
120 \mathrm{rpm} \text {; Effect of electron donors as } \\
\text { propionate, acetate, benzoate, glucose, } \\
\text { sucrose, glycerol, propylene glycol, } \\
\text { chlorophenol and cresol; Efficiency- } \\
100 \% \text { with glycerol in } 4 \text { days }\end{array}$ & [67] \\
\hline $\begin{array}{l}\text { Arthrobacter } \mathrm{sp} . \\
\text { isolated from } \\
\text { creosote polluted } \\
\text { site, MIC- } 850 \mathrm{mg} / \mathrm{L}\end{array}$ & $\begin{array}{l}\text { Synthetic } \\
\mathrm{K}_{2} \mathrm{Cr}_{2} \mathrm{O}_{7} \\
\text { solution, } 100 \\
\text { mg/L }\end{array}$ & $\begin{array}{l}100 \mathrm{~mL} \text { M9 media in } 250 \mathrm{~mL} \\
\text { Erlenmeyer flask; optimum conditions: } \\
\text { initial Cr(VI) conc.- } 45 \mathrm{mg} / \mathrm{L} \text {, temp-30 } \\
{ }^{\circ} \mathrm{C}, \mathrm{pH}-8,150 \mathrm{rpm} \text { and } 10 \mathrm{~g} / \mathrm{L} \text { glucose; } \\
\text { Efficiency-100\% }\end{array}$ & [203] \\
\hline $\begin{array}{l}\text { Pannonibacter } \\
\text { phragmitetus } \\
\text { isolated from sludge } \\
\text { of chromate factory, } \\
\text { MIC- } 1000 \mathrm{mg} / \mathrm{L}\end{array}$ & $\begin{array}{l}\text { Synthetic } \\
\mathrm{K}_{2} \mathrm{Cr}_{2} \mathrm{O}_{7} \\
\text { solution, } 100 \text { to } \\
1000 \mathrm{mg} / \mathrm{L}\end{array}$ & $\begin{array}{l}100 \text { mL Luria Bertani medium in } 250 \\
\text { mL Erlenmeyer flasks; optimum } \\
\text { conditions: initial } \mathrm{Cr}(\mathrm{VI}) \text { conc.- } 300 \\
\text { mg/L, temp.- } 37^{\circ} \mathrm{C}, 150 \mathrm{rpm} \text { and } \mathrm{pH}-9 \text {; } \\
\text { Efficiency- } 100 \%\end{array}$ & [204] \\
\hline $\begin{array}{l}\text { Bacillus } \\
\text { amyloliquefaciens } \\
\text { isolated from } \\
\text { chromite mine soil } \\
\text { samples, MIC-500 } \\
\mathrm{mg} / \mathrm{L}\end{array}$ & $\begin{array}{l}\text { Synthetic } \\
\mathrm{K}_{2} \mathrm{Cr}_{2} \mathrm{O}_{7} \\
\text { solution, } 100 \\
\text { mg/L }\end{array}$ & $\begin{array}{l}100 \mathrm{~mL} \text { nutrient media in } 250 \mathrm{~mL} \\
\text { Erlenmeyer flask, pH-7, incubation time } \\
24 \mathrm{hr} \text {, temp- } 35 \circ \mathrm{C} \text { and } 100 \mathrm{rpm} \text {; } \\
\text { Efficiency- } 100 \%\end{array}$ & [205] \\
\hline $\begin{array}{l}\text { Lab culture } \\
\text { Pseudomonas } \\
\text { mendocina }\end{array}$ & $\begin{array}{l}\text { Synthetic } \\
\mathrm{K}_{2} \mathrm{Cr}_{2} \mathrm{O}_{7} \\
\text { solution, up to } \\
25 \mathrm{mg} / \mathrm{L}\end{array}$ & $\begin{array}{l}100 \mathrm{~mL} \text { tryptic soy broth in } 250 \mathrm{~mL} \\
\text { Erlenmeyer flasks in presence of } \mathrm{Cu}(\mathrm{II}) \text {, } \\
\mathrm{Fe}(\mathrm{II}), \mathrm{Ba}(\mathrm{II}) \text { and } \mathrm{Ni}(\mathrm{II}) \text {; Efficiency-100 } \\
\% \text { in } 36 \mathrm{hr} \text { in presence of } \mathrm{Cu}(\mathrm{II})\end{array}$ & [206] \\
\hline $\begin{array}{l}\text { Streptomyces } \\
\text { violaceoruber } \\
\text { isolated from } \\
\text { wastewater } \\
\text { discharging Yellow } \\
\text { River }\end{array}$ & \begin{tabular}{|l} 
Synthetic \\
$\mathrm{K}_{2} \mathrm{Cr}_{2} \mathrm{O}_{7}$ \\
solution, 0.6 \\
$\mathrm{mM}$
\end{tabular} & $\begin{array}{l}\text { In Starch-Casein agar (SC) medium, } \\
\text { optimum temperature- } 28^{\circ} \mathrm{C} \text { and } \mathrm{pH}-7 \text {; } \\
\text { Efficiency-92.86\% in } 144 \mathrm{hr}\end{array}$ & [207] \\
\hline $\begin{array}{l}\text { Halomonas genus } \\
\text { isolated from Mono } \\
\text { Lake }\end{array}$ & $\begin{array}{l}\text { Synthetic } \\
\mathrm{K}_{2} \mathrm{CrO}_{4} \\
\text { Solution, } 2.5 \\
\mathrm{mM}\end{array}$ & $\begin{array}{l}15 \mathrm{~mL} \text { Basal medium in } 20 \mathrm{~mL} \text { serum } \\
\text { bottles at } \mathrm{pH}-10 \text { and temp- } 30{ }^{\circ} \mathrm{C} ; \\
\text { Efficiency-100\% }\end{array}$ & [208] \\
\hline
\end{tabular}




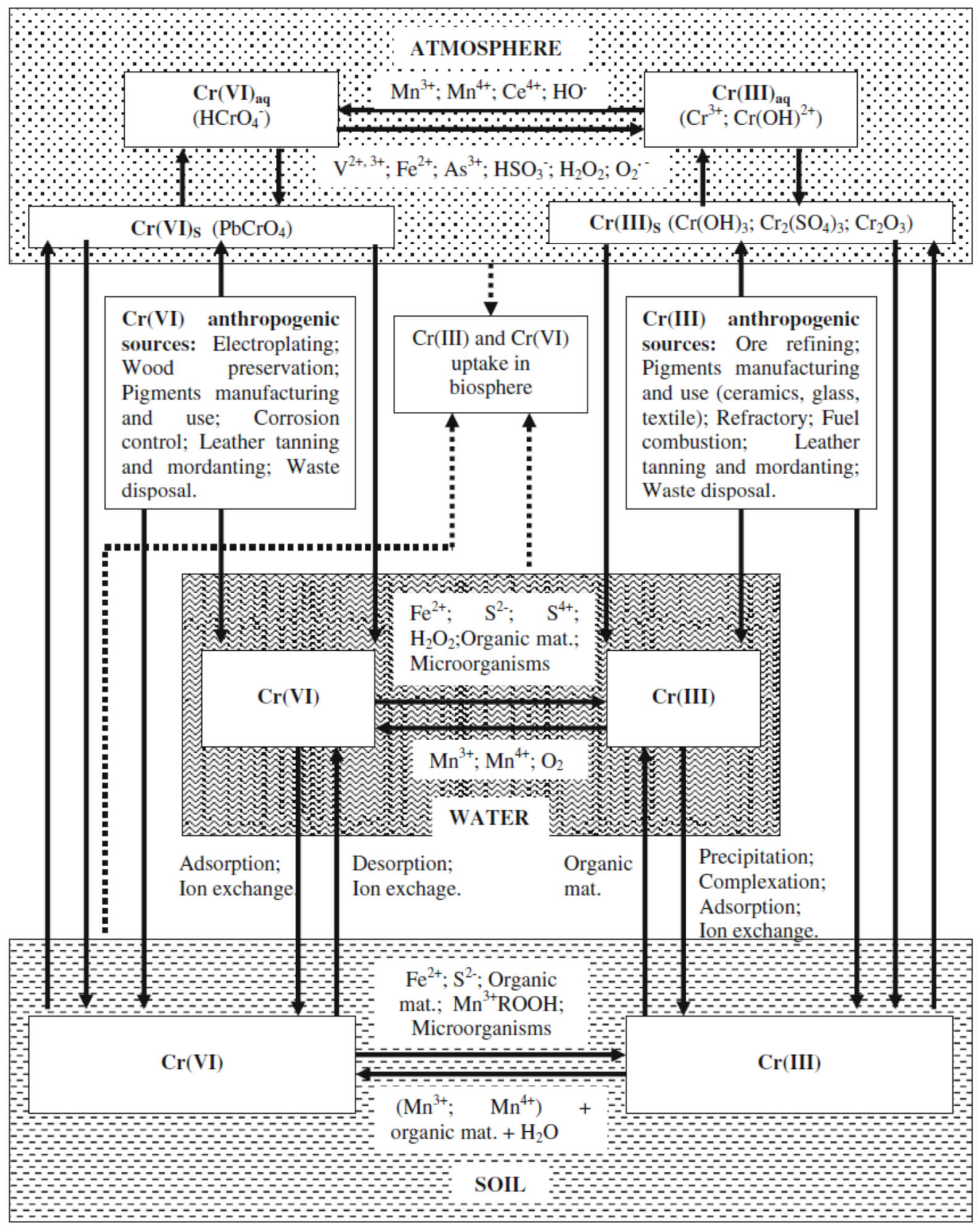

Figure 1. Biogeochemical cycle of Chromium in biosphere. [7] 


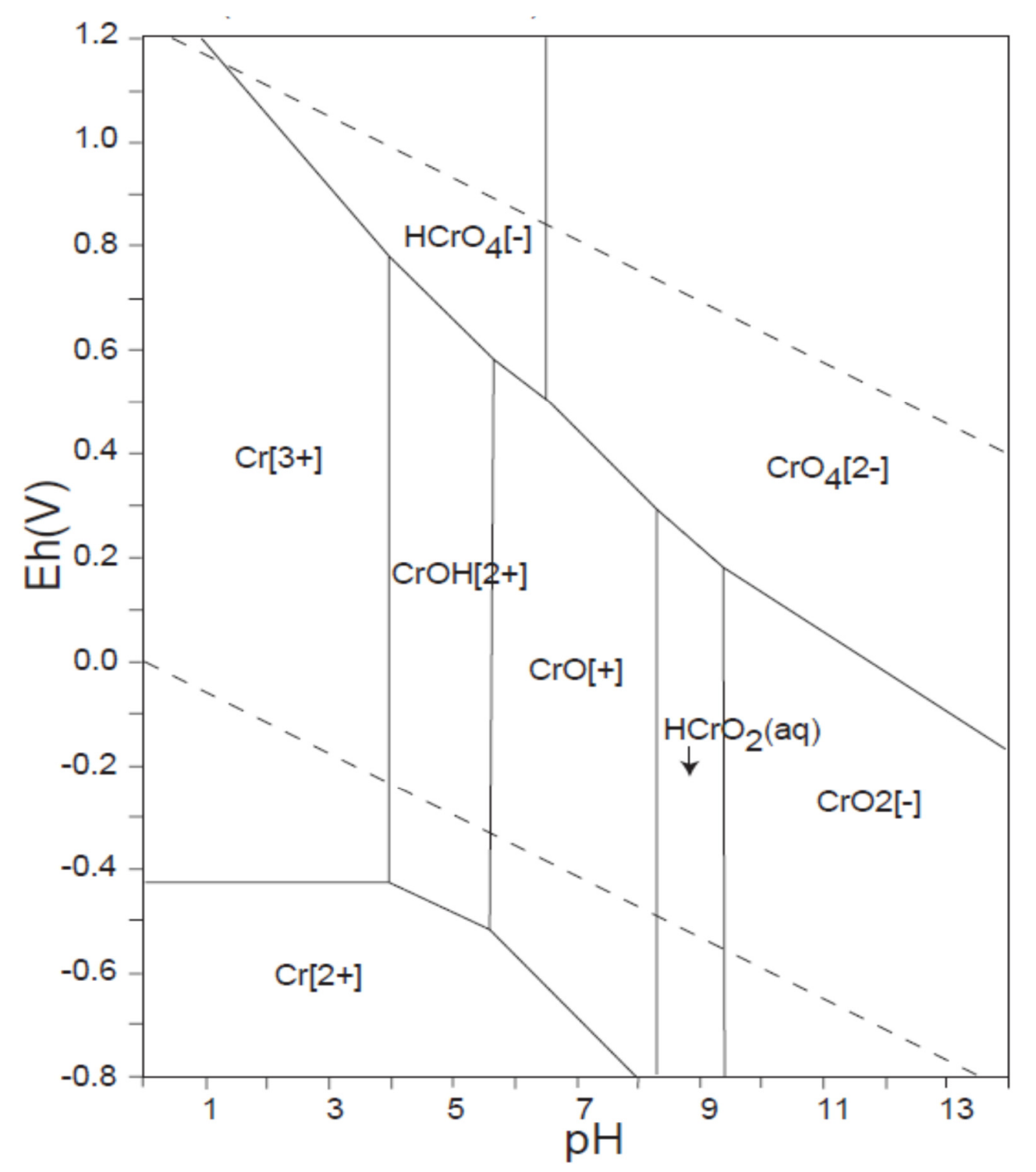

Figure 2. Eh-pH phase diagram for chromium. [183] 


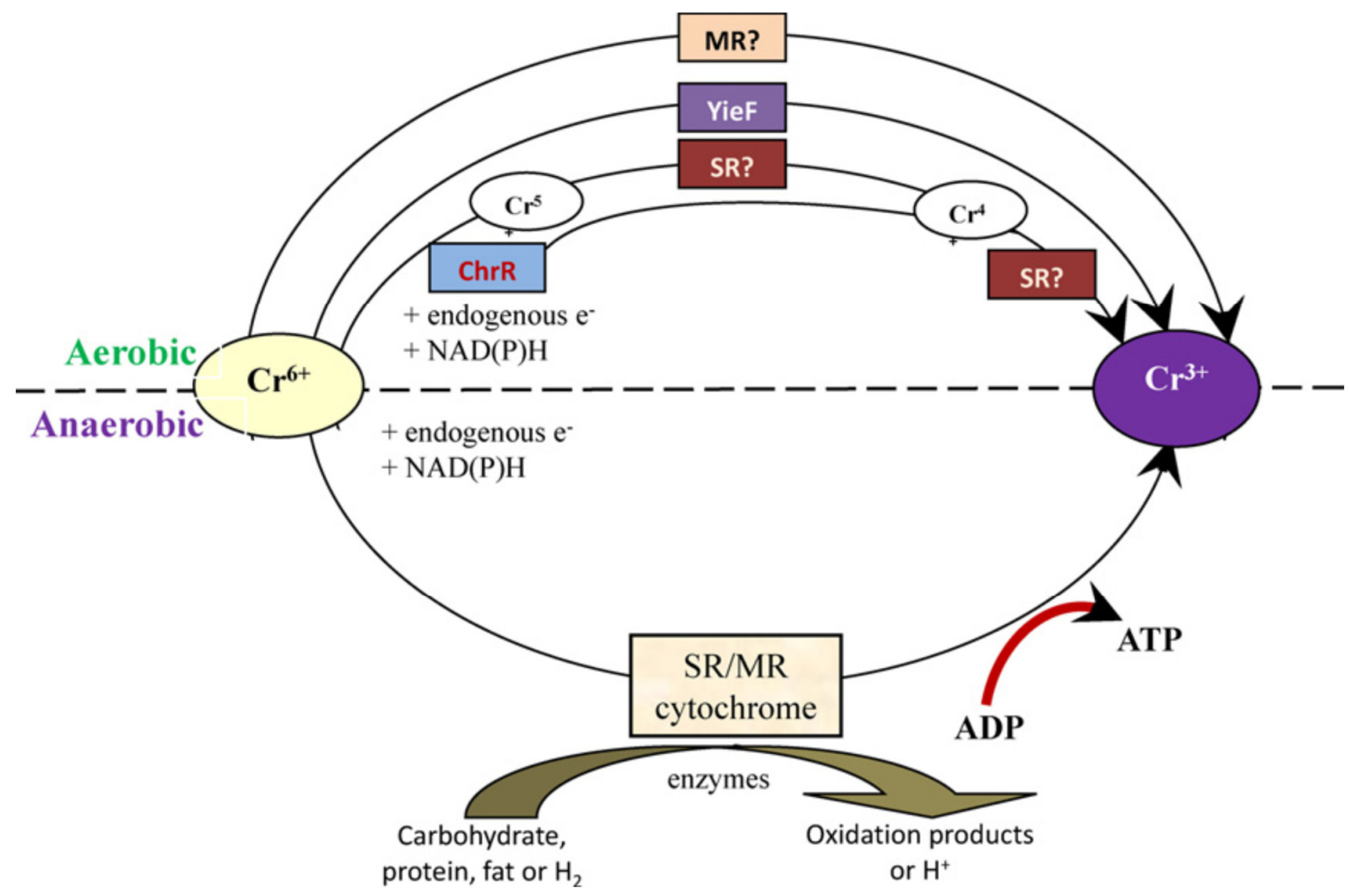

Figure 3. Mechanism of $\mathrm{Cr}(\mathrm{VI})$ reduction in aerobic and anaerobic conditions. [10] 


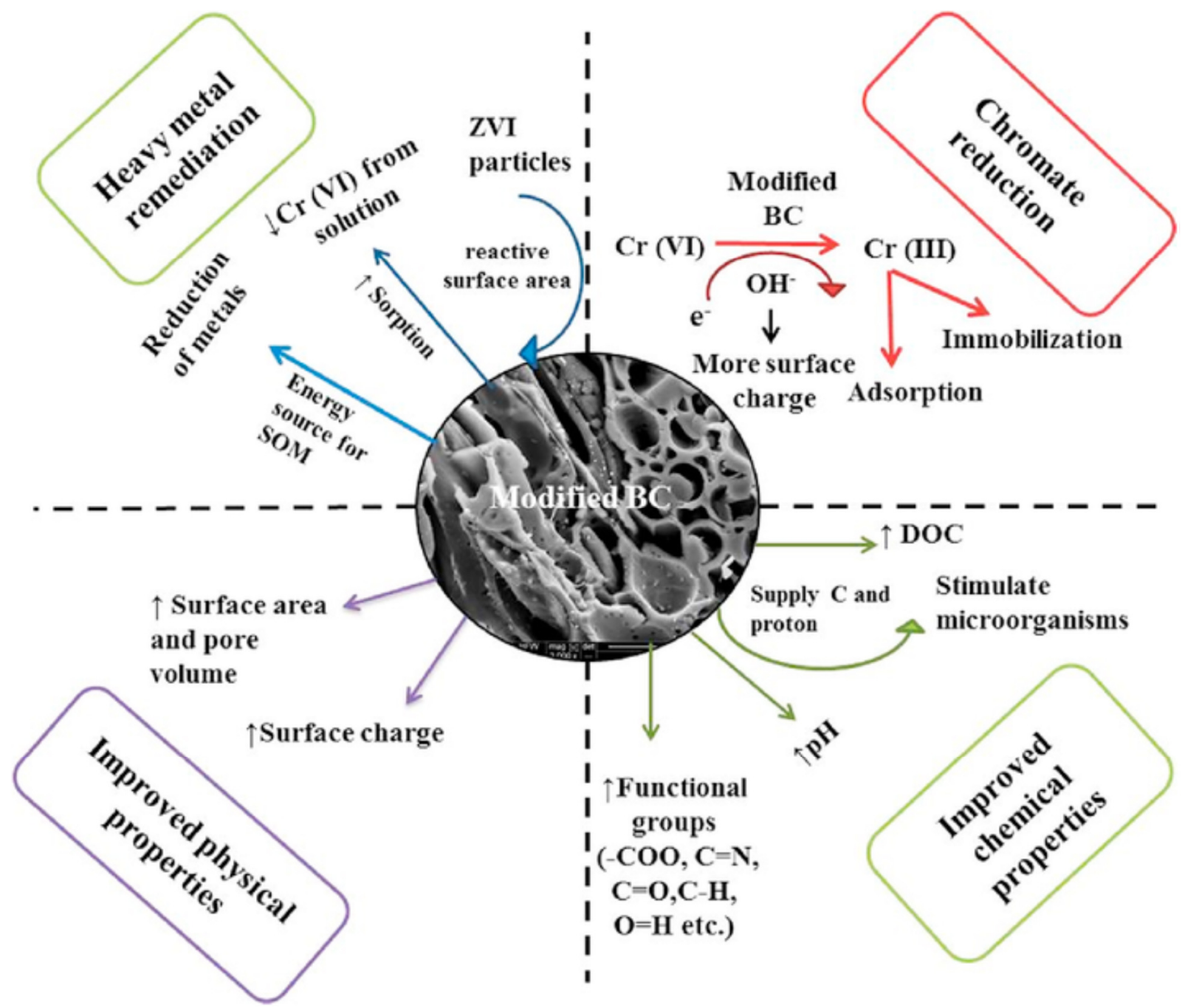

Figure 4. Cr(VI) reduction by the surface modified biochars proposed by Mandal et al.[162] 


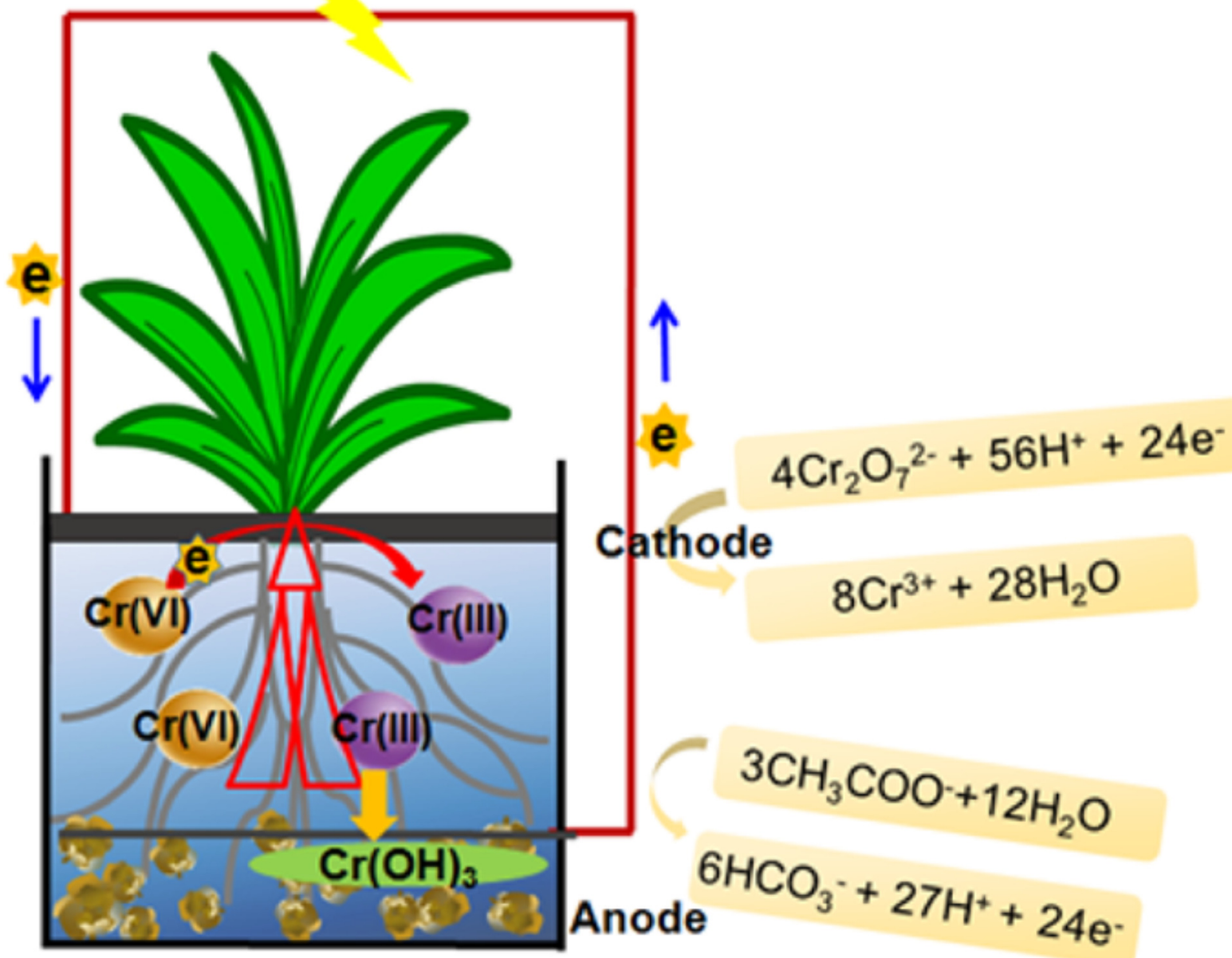

Figure 5. Schematic diagram of Ryegrass (Lolium perenne) plant-microbial fuel cell. [179] 